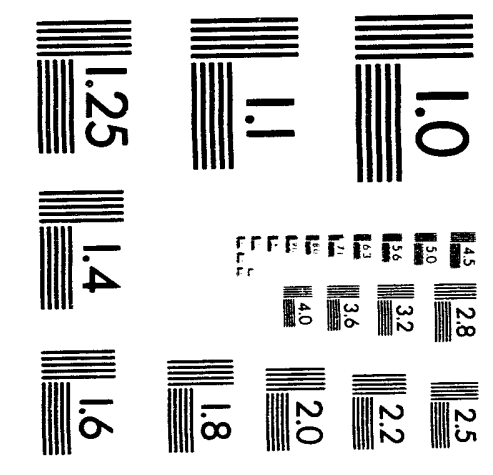



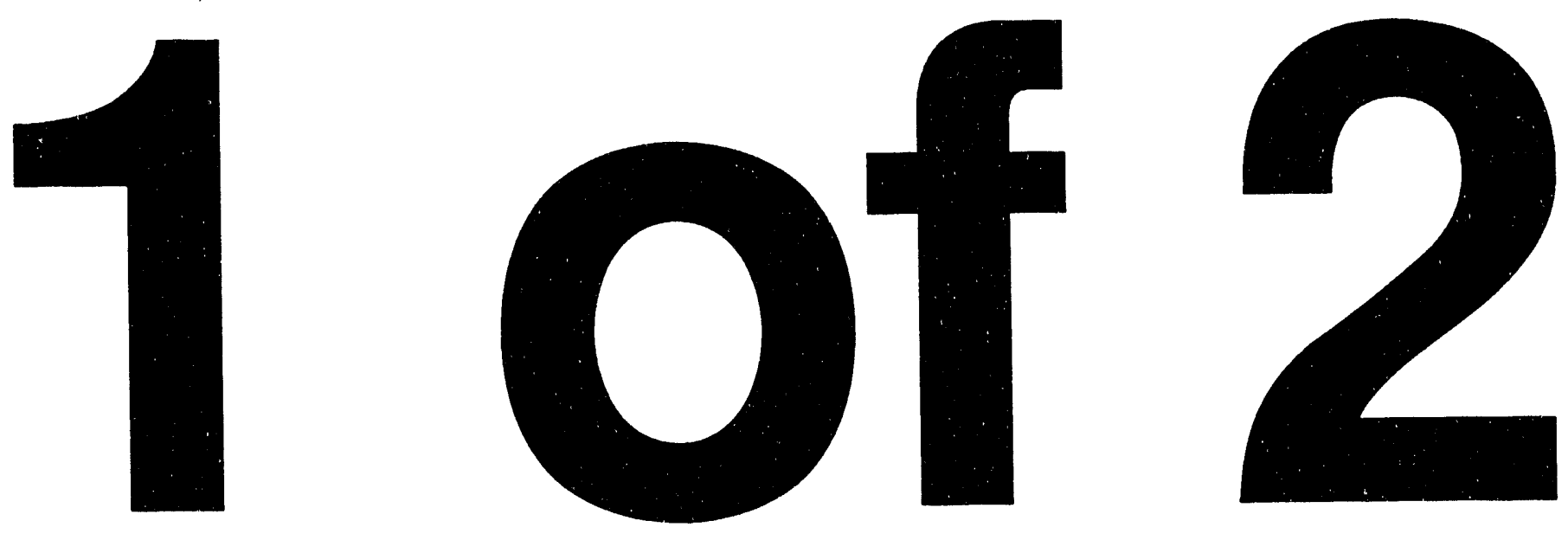


\title{
Ecotoxicity Literature \\ Review of Selected \\ Hanford Site Contaminants
}

\author{
C. J. Driver
}

March 1994

Prepared for the U.S. Department of Energy under Contract DE-AC06-76RLO 1830

Pacific Northwest Laboratory Operated for the U.S. Department of Energy by Battelle Memorial Institute 


\title{
DISCLAIMER
}

This report was prepared as an account of work sponsored by an agency of the United States Government. Neither the United States Government nor any agericy thereof, nor Battelle Memorial Institute, nor any of their employees, makes any warranty, expressed or implied, or assumes any legal liability or responsibility for the accuracy, completeness, or usefulness of any information, apparatus, product, or process disclosed, or represents that its use would not infringe privately owned rights. Reference herein to any specific commercial product, process, or service by trade name, trademark, manufacturer, or otherwise does not necessarily constitute or imply its endorsement, recommendation, or favoring by the United States Government or any agency thereof, or Battelle Memorial Institute. The views and opinions of authors expressed herein do not necessarily state or reflect those of the United States Government or any agency thereof.

\author{
PACIFIC NORTHWEST LABORATORY \\ operated by \\ BATTELLE MEMORIAL INSTITUTE \\ for the \\ UNITED STATES DEPARTMENT OF ENERGY \\ under Contract DE-ACO6-76RLO 1830
}

Printed in the United States of America

Available to DOE and DOE contractors from the

Office of Scientific and Technical Information, P.O. Box 62, Oak Ridge, TN 37831; prices available from (615) 576-8401. FTS 626-8401.

Available to the public from the National Technical Information Service, U.S. Department of Commerce, 5285 Port Royal Rd., Springfield, VA 22161. 
PNL-9394

\title{
Ecotoxicity Literature Review of Selected Hanford Site Contaminants
}

\author{
C. J. Driver
}

March 1994

Prepared for

the U. S. Department of Energy

under Contract DE-AC06-76RLO 1830

Pacific Northwest Laboratory

Richland, Washington 99352 


\section{Executive Summary}

Available information on the toxicity, food chain transport, and bioconcentration of several Hanford Site contaminants were reviewed. The contaminants included cesium-137, cobalt-60, europium, nitrate, plutonium, strontium-90, technetium, tritium, uranium, and chromium (III and VI). Toxicity and mobility in both aquatic and terrestrial systems were considered. For aquatic systems, considerable information was available on the chemical and/or radiological toxicity of most of the contaminants in invertebrate animals and fish. Little information was available on aquatic macrophyte response to the contaminants. Terrestrial animals such as waterfowl and amphibians that have high exposure potential in aquatic systems were also largely unrepresented in the toxicity literature. The preponderance of toxicity data for terrestrial biota was for laboratory mammals. Bioconcentration factors and transfer coefficients were obtained for primary producers and consumers in representative aquatic and terrestrial systems; however, little data were available for upper trophic level transfer, particularly for terrestrial predators. Food chain transport and toxicity information for the contaminants were generally lacking for desert or sage brush-steppe organisms, particularly plants and reptiles.

Food chain mobility and biotic response data for the contaminants were highly site-specific, reflecting the significant effect that numerous biological and physicochemical factors have on contaminant bioavailability and toxicity. Of the reported factors, soil and sediment conditions and presence of nutrient analogs particularly affected exposure and food chain transport.

In general, the heavy metals--chromium, cobalt, and technetium--are highly toxic to both aquatic and terrestrial biota. They tend to be retained in soils and sediments (except technetium, which rapidly moves into plants) and to accumulate in high concentrations at the lowest trophic levels. However, trophic transfer is low and no biomagnification of the metals has been reported for either aquatic or terrestrial food chains. High food chain mobility is exhibited by tritium, and the light metals, cesium and strontium. Although biomagnification does not usually occur with the light metals, in some instances cesium concentrations can increase with trophic level. Also, cesium mobility can be greatly diminished by high clay and high humic content of soil. The environmental presence of potassium and calcium affect the uptake of cesium and strontium, respectively. The toxicities of the light metals appear to be low or moderate chemically in aquatic and terrestrial organisms. The actinides, uranium and plutonium, exhibit relatively low biological mobility and are largely restricted to root systems of plants in terrestrial ecosystems. The rare-earth element, europium, exhibits low toxicity, poor assimilation and low food chain transport. Although nitrate toxicity is low for most animals, nitrate can accumulate in certain plant species to toxic levels for mammals. 


\section{Contents}

Executive Summary $\ldots \ldots \ldots \ldots \ldots \ldots \ldots \ldots \ldots \ldots \ldots \ldots \ldots \ldots \ldots \ldots \ldots$ iii

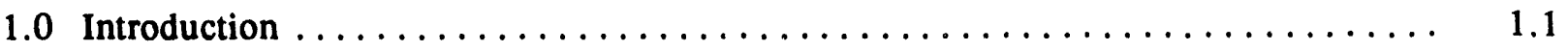

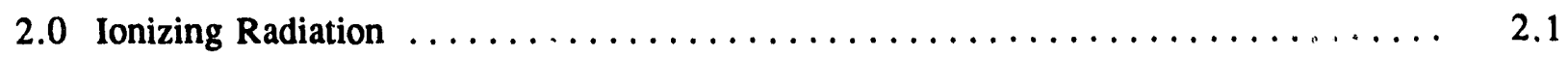

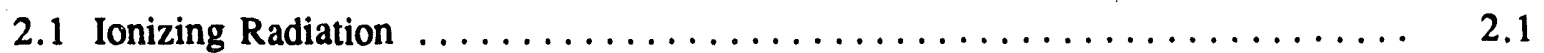

2.1.1 Ionizing Radiation Toxicity in Aquatic Biota . . . . . . . . . 2.2

2.1.2 Ionizing Radiation Toxicity in Terrestrial Biota . . . . . . . . . . . 2.2

2.2 Bioconcentration Factors and Transfer Coefficients $\ldots \ldots \ldots \ldots \ldots \ldots \ldots$

2.2.1 Radionuclide Transfer in Aquatic Systems . . . . . . . . . . . . 2.7

2.2.2 Radionuclide Transfer in Terrestrial Systems . . . . . . . . . . 2.7

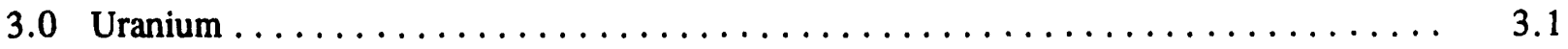

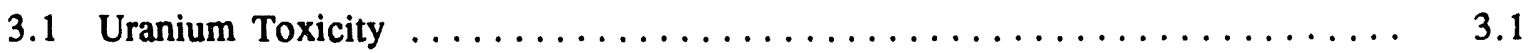

3.1.1 Uranium Toxicity in Aquatic Biota $\ldots \ldots \ldots \ldots \ldots \ldots \ldots \ldots \ldots . . \ldots \ldots$

3.1.2 Uranium Toxicity in Terrestrial Biota $\ldots \ldots \ldots \ldots \ldots \ldots \ldots . \ldots \ldots$

3.2 Bioconcentration Factors and Trophic Transfer Coefficients $\ldots \ldots \ldots \ldots \ldots \ldots$

3.2.1 Uranium Transfer in Aquatic Food Chains . . . . . . . . . . . . . . 3.11

3.2.2 Uranium Transfer Through Terrestrial Food Chains $\ldots \ldots \ldots \ldots \ldots \ldots .3 .12$

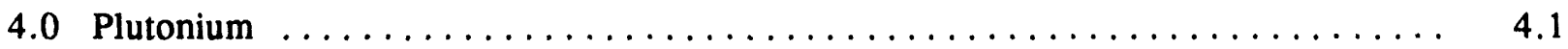

4.1 Plutonium Toxicity $\ldots \ldots \ldots \ldots \ldots \ldots \ldots \ldots \ldots \ldots \ldots \ldots \ldots \ldots \ldots \ldots \ldots \ldots \ldots \ldots, 1$

4.1.1 Plutonium Toxicity in Aquatic Biota $\ldots \ldots \ldots \ldots \ldots \ldots \ldots \ldots . \ldots \ldots$ 
4.1.2 Plutonium Toxicity in Terrestrial Biota $\ldots \ldots \ldots \ldots \ldots \ldots \ldots . \ldots .1$

4.2 Bioconcentration Factors and Trophic Transfer Coefficients . . . . . . . 4.6

4.2.1 Plutonium Transfer in Aquatic Food Chains $\ldots \ldots \ldots \ldots \ldots \ldots \ldots$

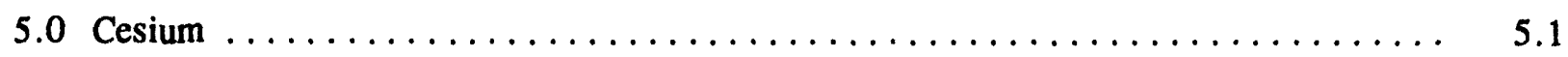

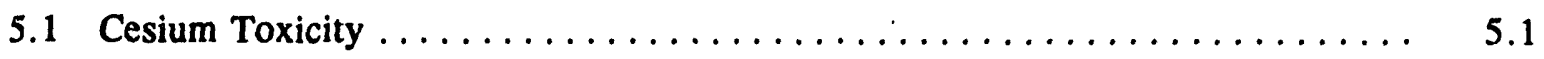

5.1.1 Toxicity of Cesium in Aquatic Biota $\ldots \ldots \ldots \ldots \ldots \ldots \ldots \ldots . \ldots \ldots$

5.1 .2 Toxicity in Terrestrial Biota $\ldots \ldots \ldots \ldots \ldots \ldots \ldots \ldots \ldots .2$

5.2 Bioconcentration Factors and Trophic Transfer Coefficients . . . . . . . 5.5

5.2.1 Cesium Transfer in Aquatic Food Chains $\ldots \ldots \ldots \ldots \ldots \ldots \ldots \ldots .5$

5.2.2 Cesium Transfer through Terrestrial Food Chains $\ldots \ldots \ldots \ldots \ldots \ldots .5 .8$

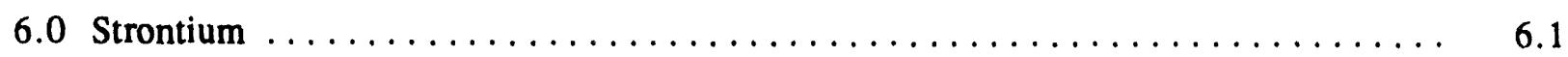

6.1 Strontium Toxicity $\ldots \ldots \ldots \ldots \ldots \ldots \ldots \ldots \ldots \ldots \ldots \ldots \ldots \ldots \ldots \ldots \ldots \ldots \ldots$

6.1.1 Toxicity of Strontium in Aquatic Biota $\ldots \ldots \ldots \ldots \ldots \ldots \ldots \ldots .1$

6.1.2 Toxicity of Strontium in Terrestrial Biota $\ldots \ldots \ldots \ldots \ldots \ldots \ldots .1$

6.2 Bioconcentration Factors and Trophic Transfer Coefficients . . . . . . . 6.3

6.2.1 Strontium Transfer in Aquatic Food Chains $\ldots \ldots \ldots \ldots \ldots \ldots \ldots . . \ldots$

6.2.2 Strontium Transfer through Terrestrial Food Chains $\ldots \ldots \ldots \ldots \ldots \ldots .6 .5$

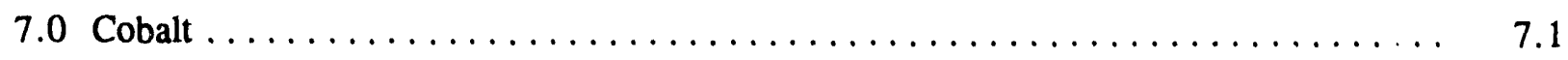

7.1 Cobalt 60 Toxicity $\ldots \ldots \ldots \ldots \ldots \ldots \ldots \ldots \ldots \ldots \ldots \ldots \ldots \ldots \ldots \ldots \ldots$

7.1.1 Cobalt-60 Toxicity in Aquatic Biota $\ldots \ldots \ldots \ldots \ldots \ldots \ldots \ldots \ldots \ldots \ldots$

7.1.2 Cobalt-60 Toxicity in Terrestrial Biota $\ldots \ldots \ldots \ldots \ldots \ldots \ldots \ldots \ldots . \ldots \ldots$ 
7.2 Bioconcentration Factors and Trophic Transfer Coefficients .......... 7.3

7.2.1 Cobalt-60 Transfer in Aquatic Food Chains $\ldots \ldots \ldots \ldots \ldots \ldots \ldots$

7.2.2 Cobalt Transfer Through Terrestrial Food Chains ............ 7.5

8.0 Chromium $\ldots \ldots \ldots \ldots \ldots \ldots \ldots \ldots \ldots \ldots \ldots \ldots \ldots \ldots \ldots \ldots \ldots \ldots \ldots$

8.1 Chromium Toxicity $\ldots \ldots \ldots \ldots \ldots \ldots \ldots \ldots \ldots \ldots \ldots \ldots \ldots \ldots \ldots \ldots \ldots$

8.1.1 Toxicity of Chromium in Aquatic Biota $\ldots \ldots \ldots \ldots \ldots \ldots \ldots \ldots . .1$

8.1.2 Toxicity of Chromium to Terrestrial Biota $\ldots \ldots \ldots \ldots \ldots \ldots \ldots .8 .5$

8.2 Bioconcentration Factors and Trophic Transfer Coefficients . . . . . . . . 8.11

8.2.1 Chromium Transfer in Aquatic Food Chains $\ldots \ldots \ldots \ldots \ldots \ldots \ldots .12$

8.2.2 Chromium Transfer through Terrestrial Food Chains ........... 8.12

9.0 Technetium $\ldots \ldots \ldots \ldots \ldots \ldots \ldots \ldots \ldots \ldots \ldots \ldots \ldots \ldots \ldots \ldots \ldots \ldots \ldots . \ldots \ldots$

9.1 Technetium Toxicity $\ldots \ldots \ldots \ldots \ldots \ldots \ldots \ldots \ldots \ldots \ldots \ldots \ldots \ldots \ldots \ldots \ldots \ldots$

9.1.1 Toxicity in Aquatic Biota $\ldots \ldots \ldots \ldots \ldots \ldots \ldots \ldots \ldots \ldots \ldots \ldots . .1$

9.1.2 Toxicity in Terrestrial Biota $\ldots \ldots \ldots \ldots \ldots \ldots \ldots \ldots \ldots \ldots \ldots .9 .1$

9.2 Bioconcentration Factors and Trophic Transfer Coefficients . . . . . . . . . 9.3

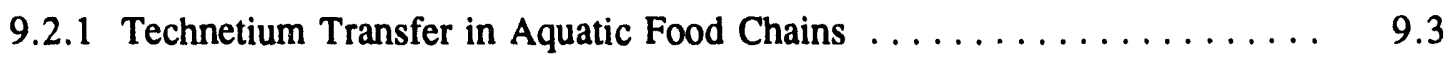

9.2.2 Technetium Transfer through Terrestrial Food Chains . . . . . . . . . 9.4

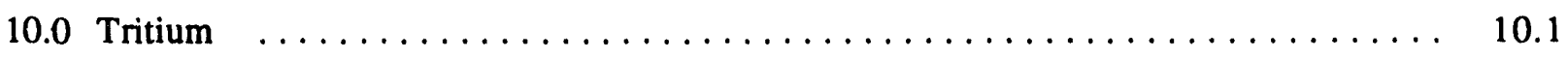

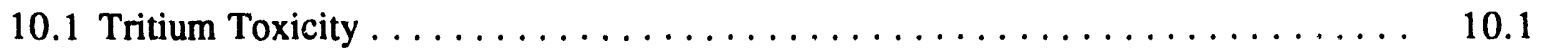

10.1.1 Toxicity in Aquatic Biota $\ldots \ldots \ldots \ldots \ldots \ldots \ldots \ldots \ldots \ldots \ldots \ldots \ldots$ 
10.1.2 Toxicity in Terrestrial Biota $\ldots \ldots \ldots \ldots \ldots \ldots \ldots \ldots \ldots \ldots \ldots . \ldots \ldots$

10.2 Bioconcentration Factors and Trophic Transfer Coefficients . . . . . . . 10.2

10.2.1 Tritium Transfer in Aquatic Food Chains $\ldots \ldots \ldots \ldots \ldots \ldots \ldots \ldots$

10.2.2 Tritium Transfer through Terrestrial Food Chains $\ldots \ldots \ldots \ldots \ldots \ldots$

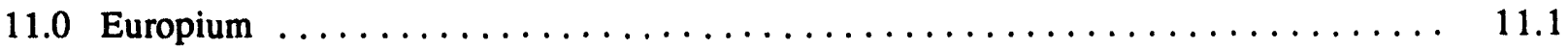

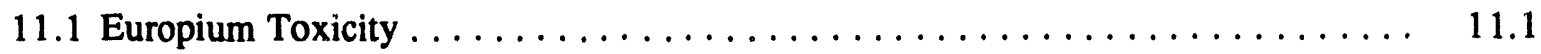

11.1.1 Europium Toxicity in Aquatic Biota $\ldots \ldots \ldots \ldots \ldots \ldots \ldots \ldots \ldots \ldots$

11.1.2 Europium Toxicity in Terrestrial Biota $\ldots \ldots \ldots \ldots \ldots \ldots \ldots \ldots \ldots \ldots$

11.2 Bioconcentration Factors and Trophic Transfer Coefficients . . . . . . . . 11.2

11.2.1 Radionuclide Transfer in Aquatic Systems $\ldots \ldots \ldots \ldots \ldots \ldots \ldots \ldots . \ldots \ldots$

11.2.2 Radionuclide Transfer in Terrestrial Systems $\ldots \ldots \ldots \ldots \ldots \ldots \ldots . \ldots$

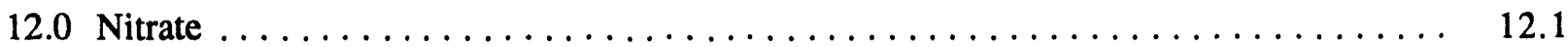

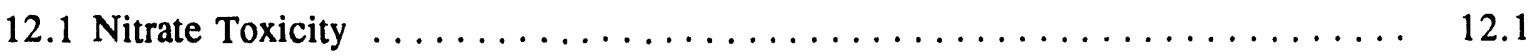

12.1.1 Nitrate Toxicity to Aquatic Biota . . . . . . . . . . . . 12.1

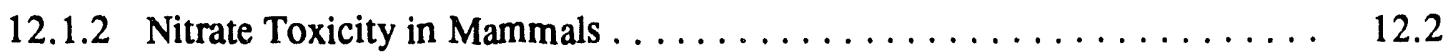

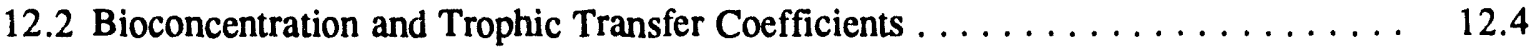

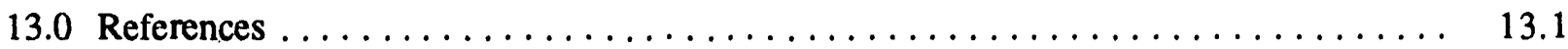

Appendix A Radiological Units and International Multiples and Submultiples $\ldots \ldots \ldots \ldots$ A.1 


\section{Tables}

2.1 Typical LD 50/30 Values for Total Body Exposure of Animals to

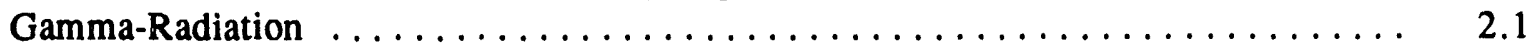

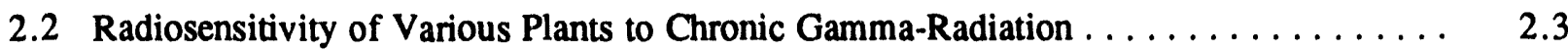

$2.3 \mathrm{LD} 50 / 30$ s of Avian Species Exposed to lonizing Radiation $\ldots \ldots \ldots \ldots \ldots \ldots \ldots$

2.4 Concentration Factors of Beta Emitters in Birds Using the Columbia River in the Vicinity of the Hanford Site, $1956-1959 \ldots \ldots \ldots \ldots \ldots \ldots \ldots \ldots \ldots \ldots \ldots$

3.1 Acute Toxicity of Uranium in Aquatic Invertebrates $\ldots \ldots \ldots \ldots \ldots \ldots \ldots \ldots$

3.2 Acute Toxicity of Uranium to Freshwater Fish $\ldots \ldots \ldots \ldots \ldots \ldots \ldots \ldots \ldots$

3.3 Lowest Concentrations of Uranium in Food and Drinking Water Causing Adverse Health Effects in Mammals . . . . . . . . . . . . . . . . . . . . .

3.4 Lowest Concentrations of Airborne Uranium Causing Adverse Health Effects in

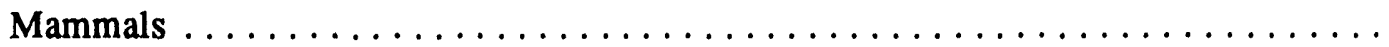

3.5 Lowest Concentrations of Uranium that Caused Adverse Health Effects when Appiied to the Skin of Rabbits . . . . . . . . . . . . . . . . . . . . . . . . .

3.6 Accumulation of Uranium in Plant and Soil Invertebrates as Related to Soil Type ...

4.1 Sediment-Based Trophic Transfer Coefficients for Plutonium-727 in Biota of an

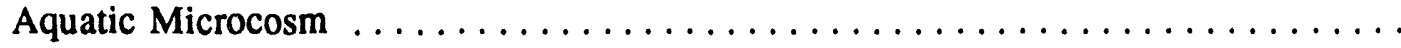

4.2 Concentration Ratios for Plutonium in Desert Mammals $\ldots \ldots \ldots \ldots \ldots \ldots \ldots \ldots$

5.1 Biological Half-Lives of Cesium-137 in Small Mammals Native to the Hanford Site . . $\quad 5.4$

5.2 Water-Based Concentration Factors for Cesium in the Aquatic Food-Chain . . . . . . 5.5

5.3 Bioconcentration Factors for Cesium in Fish Based on Cesium Levels in Water . . . . . 5.7

5.4 Sediment-Based Bioconcentration Factors for Cesium in a Biotic Community $\ldots \ldots .8$ 
5.5 Cesium Concentration Factors in Birds $\ldots \ldots \ldots \ldots \ldots \ldots \ldots \ldots \ldots \ldots$

5.6 Concentration Factors for Cesium in the Terrestrial Food Chain $\ldots \ldots \ldots \ldots \ldots$

5.7 Species-Specific Concentration Factors for Cesium in Terrestrial Ecosystems $\ldots \ldots . \quad 5.10$

6.1 Observed Ratios Reported for Strontium/Calcium Transport in Food Webs . . . . . . 6.4

6.2 Concentration Factors for Strontium in the Aquatic Food Chain $\ldots \ldots \ldots \ldots \ldots$

6.3 Strontium Bioconcentration and Transfer Factors for Stream-Dwelling Organisms _. 6.6

6.4 Concentration Factors for Strontium in the Terrestrial Food Chain $\ldots \ldots \ldots \ldots \ldots .7$

7.1 Concentration Factors for Cobalt in the Aquatic Food Chain $\ldots \ldots \ldots \ldots \ldots \ldots$

7.2 Concentration Factors for Cobalt in the Terrestrial Food Chain . . . . . . . . 7.5

8.1 Acute Toxicity of Hexavalent and Trivalent Chromium in Aquatic Invertebrates . . . $\quad 8.3$

8.2 NOAELs and LOAELs Reported for Hexavalent and Trivalent Chromium in

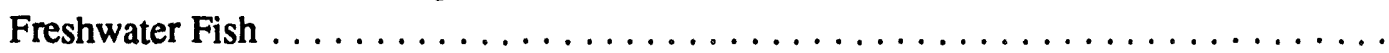

8.3 Acute LC50 Values Reported for Chromium in Freshwater Fish $\ldots \ldots \ldots \ldots \ldots$

8.4 Chromium Concentrations in Organisms from Contaminated Terrestrial Systems . . . $\quad 8.13$

10.1 Specific Activity Ratios in Mammals after Continuous Tritium Intake . . . . . . 10.4

10.2 Biological Half-Lives of Tritium in Body Water of Mammals and Birds $\ldots \ldots \ldots \ldots .4$

12.1 LC50 Values for Nitrate in Freshwater Fish $\ldots \ldots \ldots \ldots \ldots \ldots \ldots \ldots \ldots \ldots \ldots \ldots$

12.2 Plants Known to Accumulate Nitrate $\ldots \ldots \ldots \ldots \ldots \ldots \ldots \ldots \ldots \ldots \ldots \ldots \ldots$ 


\section{Figure}

3.1 Relationship Between Acute Toxicity of Uranium to Freshwater Fish and the Total Hardness of the Test Water 
.

. 


\subsection{Introduction}

This document summarizes the licerature available on the environmental effects of several Hanford Site contaminants. The contaminants were selected using information from ongoing Comprehensive Environmental Response, Compensation, and Liability Act (CERCLA) investigations for operable units 200-BP-1, 300-FF-5, 100-BC-1, 100-DR-1, 100-HR-1 and 100-BC-5.

Westinghouse Hanford Company requested Pacific Northwest Laboratory(a) to prepare this document in response to requirements set forth in the Tri-Party Agreement milestone document "Columbia River Impact Evaluation Plan" (U.S. DOE/RL 1993). Specifically, the plan identifies the need for several tasks to provide information for human health and ecological risk assessments, including the development of an ecotoxicology literature review (Activity 4-1).

The information compiled in this report can be used both to 1) provide background information to operable unit managers in the U.S. Department of Energy, U.S. Environmental Protection Agency, and State of Washington Department of Ecology, and 2) provide ecotoxicological profiles for the ecological risk assessments.

Available information was reviewed on the sensitivity of plants and animals to cesium-137, cobalt60 , europium, nitrate, plutonium, strontium-90, technetium, tritium, uranium, and chromium (III and VI). As the CERCLA investigations and ecological risk assessments proceed, the document may be revised to include additional contaminants. Particular emphasis was given to transfer coefficients of the contaminants from water and soil to biota.

Information on each of the contaminants was obtained from open literature reports dating from the early 1900 s to the present. Ten commercial online bibliographic data bases were used to obtain citations for each of the contaminants. The bibliographic source files searched were BIOSIS, AGRICOLA, National Technical Information Service, Science Citation, Environmental Bibliography, Enviroline, Pollution Abstracts, Toxline, Energy Science and Technology, and Nuclear Science Abstracts. Pre-1948 citations were obtained from hand searches of bibliographic indices and from references cited in later publications. Except where indicated, data were obtained from primary sources.

Data for species relevant to the Hanford Site are emphasized in this report. However, uptake and toxicity data for local species are augmented, where necessary, with data from other North American species. The response and sensitivity to heavy metals and radionuclides for tropical fish are within ranges reported for Northern Hemisphere species (Skidmore and Firth 1983; Bywater et al. 1991); therefore, information obtained from tropical fish studies are also included.

(a) Pacific Northwest Laboratory is operated for the U.S. Department of Energy by Battelle Memorial Institute under Contract DE-AC06-76 RLO 1830. 
In addition, available data on the toxicokinetics of the contaminants are reported because the relative rates of uptake and loss of a chemical and its distribution within the organism determine its exposure. Also identified are those factors that influence the uptake and toxicity of the particular contaminants in organisms from both aquatic and terrestrial systems. Information on contaminantspecific lesions or changes that provide biomarkers of exposure or indices of injury are also provided.

Bioconcentration factors and transfer coefficients were reported for representative species of each trophic (feeding) level within freshwater and terrestrial ecosystems, when available. A bioconcentration factor is defined as the concentration of a given chemical in an organism divided by the concentration of the same chemical in the environment of that organism. For terrestrial organisms, the bioconcentration factor for organisms in each trophic level is based on the concentration found in the soil. In aquatic systems, the bioconcentration factor can be based on the water concentration or the level of the contaminant found in the sediment. Bioaccumulation factor, concentration ratio, discrimination factor, uptake coefficient, and concentration factor are terms synonymous with bioconcentration factor in the scientific literature. The term "transfer coefficient" may either refer to the bioconcentration factor or describe the ratio between the concentration of a chemical in an organism to the concentration of the same chemical in the biota that constitute that organism's food source. When used in the latter manner in this report, the food source is identified from which the chemical is transferred.

Comparing transfer coefficients and bioconcentration factors for plants reported by different researchers is difficult because of the inconsistency of reporting values based on dry weight or wet weight of the plant tissue. Although concentration values based on wet weights of plants have a more direct application to food chain uptake predictions, they are much less accurate than those based on dry weights (DOE 1974). In 1974, the Department of Energy standardized reporting of transfer coefficients and bioconcentration factors to a dry weight basis to alleviate the problem of data comparability. However, data prior to this time and data from non-DOE sponsored programs are often reported as wet weight values. The dry or wet weight basis is indicated for the bioconcentration factors and transfer coefficients listed in this document.

The radiation toxicity and general trophic level accumulation and transfer of radionuclides are summarized separately from the specific radiobiological effects and chemical toxicity reported for each specific radionuclide.

An explanation of the various dose and exposure units used in radiation toxicity research is provided in Appendix A. 


\subsection{Ionizing Radiation}

\subsection{Ionizing Radiation Toxicity}

Ionizing radiation can cause damage to all biological systems; however, the sensitivity of organisms varies greatly. In general, larger herbivorous mammals are most vulnerable to ionizing radiation. The next sensitive group of organisms include the smaller mammals, birds, herbivorous insects, filter-feeding aquatic invertebrates, higher plants, and lower plants. Simpler life forms including unicellular plants and animals, bacteria, and viruses are more resistent to the lethal effects of radiation. Also, organisms in rapidly growing stages of their life cycle are more radiosensitive than mature organisms (Krumholz et al. 1957; Whicker and Schultz 1982; Bond et al. 1965; Gleiser 1953; Rust et al. 1954). The relative sensitivities of various organisms to ionizing radiation are shown in Table 2.1.

Table 2.1. Typical LD 50/30(a) Values for Total Body Exposure of Animals to Gamma-Radiation

$\begin{array}{lr}\text { Organism } & \text { LD50/30 (rads) } \\ \text { Sheep } & 200-300 \\ \text { Swine } & 200-300 \\ \text { Dog } & 350 \\ \text { Guinea Pig } & 400 \\ \text { Man } & 250-400 \\ \text { Mouse } & 550 \\ \text { Monkey } & 600 \\ \text { Rat } & 750 \\ \text { Rabbit } & 800 \\ \text { Chicken } & 600 \\ \text { Song Sparrow } & 800 \\ \text { Goldfish } & 2,300 \\ \text { Frog } & 700 \\ \text { Tortoise } & 1,500 \\ \text { Fruit Fly } & 100,000 \\ \text { Bacteria } & 500,000 \\ \text { Virus } & 1,800,000\end{array}$

(a) LD50/30 is the observed dosage of radionuclide that is required to kill $50 \%$ of a group of animals in $\mathbf{3 0}$ days. 


\subsubsection{Ionizing Radiation Toxicity in Aquatic Biota}

The ionizing radiation toxicity in aquatic invertebrates and fish is reviewed below.

\section{Invertebrates}

An LD50 of $500 \mathrm{R}$ has been reported for crustaceans (King 1964). The reproductive ability of a hermaphroditic snail was greatly reduced by radiation exposures between 4000 and $9000 \mathrm{R}$ (Perlowagora-Szumlewicz 1964). Permanent sterility was caused by an accumulated dose of 10,500 R in the cladoceran, Daphnia magna (King 1964), and depressed reproduction was observed in Daphnia magna populations exposed to $10^{-5} \mathrm{Ci} / \mathrm{L}$ for 80 days (Klechkovskii et al. 1973).

\section{Fish}

King (1964) reported a general LD50 value for fish of 90,000 R. The 50\% survival dose for male germ cells of medaka, a small teleost fish, at hatching was 390 to 500 rad for beta radiation and 500 to $520 \mathrm{rad}$ for gamma emissions (Etoh and Hyodo-Taguchi 1983a, Hyodo-Taguchi and Etoh 1986). For beta radiation, the $50 \%$ survival dose for female germ cells in fish at hatching was $140 \mathrm{rad}$. The $50 \%$ survival dose for female germ cells exposed to gamma-radiation was 305 rad (Etoh and Hyodo-Taguchi 1983b). Population growth of white crappie (Pomoxis sparoides), largemouth black bass (Micropterus salmoides) and the redhorse (Moxostoma erythrurum), declined by $25 \%$ when exposed to $57 \mathrm{R} / \mathrm{yr}$ external radiation (and unknown internal radiation) in a contaminated lake and creek.

\subsubsection{Ionizing Radiation Toxicity in Terrestrial Biota}

The following sections provide data on the ionizing radiation toxicity in terrestrial biota.

\section{Plants}

Plants are relatively resistant to ionizing radiation. The effects of chronic irradiation (6 months) of a late successional oak-pine forest were studied at Brookhaven National Laboratory (BNL) in New York. Changes in ecosystem structure, diversity, primary production, total respiration, and nutrient inventory occurred. The most resistant species were the ones commonly found in disturbed places, i.e., generalists capable of surviving a wide range of conditions. Mosses and lichens survived exposures greater than $1000 \mathrm{R} / \mathrm{d}$. No higher plants survived greater than $200 \mathrm{R} / \mathrm{d}$. Sedge (Carex pennsylvanica) survived 150 to $200 \mathrm{R} / \mathrm{d}$. Shrubs (Vaccinium and Quercus ilicifolia) survived 40 to $150 \mathrm{R} / \mathrm{d}$. Oak trees survived up to $40 \mathrm{R} / \mathrm{d}$, whereas pine trees were killed by $16 \mathrm{R} / \mathrm{d}$. No change was noted in the number of species in an oak-pine forest up to $2 \mathrm{R} / \mathrm{d}$, but changes in growth rates were detected at exposures as low as $1 \mathrm{R} / \mathrm{d}$ (Woodwell 1970). Severe defects were observed in Tradescatia at an exposure rate of $40 \mathrm{R} / \mathrm{d}$. However, an exposure of $6000 \mathrm{R} / \mathrm{d}$ was required to produce the same 
effect in a hybrid gladiolus (Odum 1956). The sensitivity of various plant species appears to be related to the cross-sectional area of the nucleus in relation to cell size: the larger the nucleus and chromosome volume, the more sensitive the plant (Underbrink and Sparrow 1968, 1974). The radiosensitivity of plants to gamma-radiation is listed in Table $\mathbf{2 . 2}$.

\section{Invertebrates}

Although viability and reproduction are reduced in insects exposed to ionizing radiation, the level of exposure required to induce these effects is quite high. Sterilization of the screw worm fly (Callitroga) occurred at $500 \mathrm{R}$, whereas the fruit fly (Drosophila) required an exposure of 16,000 $\mathrm{R}$ to induce sterilization, and the powder post beetle (Lyctus) required 32,000 R. The LD50 for adult fruit flies was about $10^{5} \mathrm{R}$. The LD50 for fly eggs was about $190 \mathrm{R}$ (Packard 1936). Reduction of egg viability was observed in the European corn borer after exposure to $2500 \mathrm{R}$ (Walker and Brindley 1963).

\section{Mammals}

Lethal effects are observed in most mammals at acute radiation doses in excess of $200 \mathrm{rad}$ (Myers 1989). Mortality results from failure of the hematopoetic system. Radiation injuries most significant to animal populations are those affecting life span and reproduction. In laboratory rodents, survival time was shortened by $10 \%$ when the radiation dose was more than half the LD50/30 dose for that species (Bacq and Alexander 1961). Reproductive cells are the most radiosensitive cells of the mammalian system, and fertility in laboratory animals has been reduced by ionizing radiation. Acute exposures of a few hundred roentgens rendered male mice temporarily sterile. Smaller doses (100 R) resulted in permanent sterility in females (Oakenberg and Clark 1964). The difference in reproductive sensitivity to radiation is due to the presence of spermatogonia in males and the lack of

Table 2.2. Radiosensitivity of Various Plants to Chronic Gamma-Radiation

\begin{tabular}{|c|c|c|c|c|}
\hline \multirow[b]{2}{*}{ Plant } & \multirow{2}{*}{$\begin{array}{l}\text { Length of Exposure } \\
\text { (weeks) }\end{array}$} & \multicolumn{3}{|c|}{ Exposure to Produce Effect (R/d) } \\
\hline & & None & Mild & Severe \\
\hline Lilim (hybrid) h.v. Tangel (Lily) & 8 & 10 & 20 & 40 \\
\hline Tadescantia paludosa (Spiderwort) & 12 & 15 & 20 & 40 \\
\hline Wicia faba (Broad Bean) & 15 & 30 & 60 & 90 \\
\hline Nicotian rustic (Tobacco) & 15 & 50 & 100 & 400 \\
\hline Sedum spurium (Stonecrop) & 14 & 255 & 528 & 760 \\
\hline Sedum sieboldi (Stonecrop) & 13 & 1000 & 2500 & 4100 \\
\hline Galdolus (Gladiola) & 12 & 800 & 1500 & 5000 \\
\hline Luzula Acuminata (Wood Rush) & 12 & 1720 & 2600 & 6000 \\
\hline
\end{tabular}


a comparable regenerative stem cell in the ovary (i.e., oocytes cannot be replaced once they are destroyed). Differences in reproductive sensitivity to ionizing radiation among species were largely found in the responses of the females and were probably a result of the different rates of ova development among species, particularly the stage at which the oocyte remains until follicle maturation. In contrast, the radiation response of the male was typical for all species (Oakenberg and Clark 1964, Roderick 1964). Male organisms as diverse as the grasshopper, fruit fly, silkworm, and guinea pig have shown very similar responses to ionizing radiation because of the similarity of spermatogenesis (French 1965). In addition to causing sterility, acute exposure can decrease the number of young produced by the irradiated parent. An acute dose of $30 \mathrm{R}$ in young female mice significantly reduced the number of offspring produced. Exposures of about $400 \mathrm{R}$ in males decreased production of young (Rugh 1964). The reduction in young is attributable to dominant lethal mutations. Sonatic effects on the female parent also contribute to loss of young. The cost in number of offspring per litter was 0.009 mice $/ R$ if the male parent was irradiated and 0.027 mice $/ R$ if the female parent received the dose (Touchberry and Verley 1964). Chronic exposure to radiation for more than $2 \mathrm{R} / \mathrm{d}$ resulted in sterility in male rats (Brown et al. 1964). In mice, sterility resulted from exposure to $3 \mathrm{R} /$ day (Stadler and Gowen 1964). Although wild rodents were more resistant to radiation exposure in relation to lethality (Gambino and Linberg 1964), it is not known if the reproductive system of the wild rodents is correspondingly resistant as well.

Chronic exposure to $0.83 \mathrm{R} /$ day of gamma radiation has been reported to decrease survival of the desert rodent (Perognathus formosus). The observed population decline was calculated to cause a reduction in the multiplication rate per generation of $40 \%$ (French et al. 1974). However, the test design did not include replicates of the irradiated plot, thus making rauses of population differences between control and irradiated plots unclear. Indeed, for life expectancy, the only population parameter subjected to statistical testing, the estimates for the three plots (one irradiated plot and two control plots) were all statistically different $(p<0.001)$ indicating that the differences the authors ascribe to radiation could be caused by any number of other factors.

At relatively high doses delivered at high dose rates, ionization radiation is carcinogenic and mutagenic in laboratory animals. However, the dose-response curve at low doses is ambiguous. As a conservative position, ionizing radiation is considered carcinogenic at dose rates that extend down to doses that could be received from environmental exposures. Estimates of cancer risk are based on the absorbed dose of radiation in an organ or tissue, and the cancer risk at a particular dose is the same regardless of the source of the radiation. However, the chemical properties of the radionuclide influence the distribution, biological half-life, and retention of the radionuclide within a target organ. Genetic damage, such as gene mutation or chromosomal aberrations, has been demonstrated in experimental animals (CBEIR 1980, 1988, 1990; UNSCEAR 1982, 1986, 1988). High-energy betaradiation (0.61 MeV strontium, $0.31 \mathrm{MeV}$ cobalt-60, and $0.55 \mathrm{MeV}$ cesium-137) causes deep injury to the dermis layer of the skin with subsequent development of chronic radiation dermatitis. Chronic radiation dermatitis is characterized by persistent exfoliation and, in some instances, progressive precancerous lesions in the skin (Jones and Hunt 1983). 
Biomarkers of Radiation Exposure. Lethal doses of ionizing radiation induce pervasive hemorrhages throughout the body, particularly in the gastrointestinal tract. Generally, microscopic lesions are not unique. However, a characteristic "severance," or separation, of the epiphyseal cartilage from the spongy bone on the diaphyseal side has been described (Bloom 1948).

\section{Birds}

As a group, birds appear to be at greater risk of beta-gamma radiation exposure than other wild animals. About $33 \%$ of birds collected from a contaminated area had radiation counts above the background level, whereas only $7 \%$ of the mammals collected, and $5 \%$ of the reptiles collected had higher-than-background counts. The higher rate of contamination was attributed to the grit-use behavior of birds (Bellamy et al. 1949).

The LD50/30s for wild bird species exposed to ionizing radiation range from 485 to $2500 \mathrm{rad}$ (average 790) and are listed in Table 2.3. No gross effects were observed in birds at a waste disposal site with body burdens greater than $5 \mu \mathrm{Ci}$ of radioactivity (Willard 1960). Twenty-three species of birds from areas containing 10 to 100 times normal background radiation $(1.0$ to $4.0 \mathrm{mR} / \mathrm{h})$ were monitored for health effects (Maslov et al. 1967). Increased mitotic abnormalities and inhibition of cell division of the comea in the birds were observed. However, no other changes were induced, even in radiosensitive organs (bone marrow, spleen, and gonads). The stress of the ionizing radiation added to the existing stresses of predation, weather, and diminished food quantity or quality were noted but unquantifiable (Willard 1960). Reproductive populations of tree swallows (Iridoprocne bicolor), rufous-sided towhees (Pipilo ertyhrophthalmus), brown thrasher (Toxostoma rufum), Baltimore oriole (Icterus galbula), and eastern blue bird (Sialia sialis) ner ting in the vicinity of the radiation source in the oak-pine forest at BNL were adversely affected by the radiation. The dose found to be lethal to $100 \%$ of exposed eggs of wild passerines was between 500 and $1000 \mathrm{R}$ at a dose rate up to $50 \mathrm{R} / \mathrm{d}$. The adult mortality rate approached $100 \%$ at about $2000 \mathrm{R}$ at a dose rate of up to $150 \mathrm{R} / \mathrm{d}$ (Wagner and Marples 1966). External exposure to gamma-radiation of up to $600 \mathrm{R}$ did not result in the mortality of embryos or nestlings of passerine species (Zach and Mayoh 1984, 1986a, 1986b). Chronic irradiation with 960 rad over 20 days reduced hatchability in domestic chicken (Gallus domesticus) and black-headed gull (Larus ridibundus) eggs (Phillips and Coggle 1988). A decrease in hatchability of greater than $40 \%$ was observed in tree swallow embryos exposed to $1.0 \mathrm{~Gy} / \mathrm{d}$ (Zach and Mayoh 1986b). Mraz (1971) found that exposure of chicken eggs to $0.4 \mathrm{~Gy} / \mathrm{d}$ resulted in a significant decrease in hatchability.

High sublethal doses of ionizing radiation did not affect pair-formation in green-winged teal or territorial behavior of the shoveler (Tester et al. 1968). In pheasants (Phaisanus colchincus), single exposures to the ovaries of 500 to $2025 \mathrm{R}$ and cumulative exposures from 500 to $5316 \mathrm{R}$ did not affect egg production, plumage coloration, or ovarian tissue structure (Greb 1955; Greb and Morgan 1961). Irradiation of female eastern bluebirds and their eggs at $23.5 \mathrm{R} / \mathrm{min}$ for accumulated doses of 200 to $600 \mathrm{R}$ did not alter clutch size, hatching success, nestling period, or fledgling success (Norris 
Table 2.3. LD50/30s of Avian Species Exposed to Ionizing Radiation

\begin{tabular}{|c|c|c|c|}
\hline Species & Age & $\mathrm{LD} 50 / 30(\mathrm{R})$ & Reference \\
\hline Blue-Winged Teal (Anas discors) & Adult & 715 & Tester et al. 1968a \\
\hline Green-Winged Teal (Anas crecca) & Adult & 485 & Tester et al. 1968a \\
\hline Shoveler (Anas clypeata) & Adult & 894 & Tester et al. 1968a \\
\hline Mallard (Anas platyrhynchos) & $\begin{array}{l}4 \text { months } \\
12 \text { months }\end{array}$ & $\begin{array}{l}704 \\
630\end{array}$ & $\begin{array}{l}\text { Abraham } 1972 \\
\text { Cumow et al. } 1970\end{array}$ \\
\hline Bluebird (Sialia sialis) & $\begin{array}{l}\text { Adult } \\
\text { Fledgling }\end{array}$ & $\begin{array}{l}2500 \\
500-600(a)\end{array}$ & $\begin{array}{l}\text { Willard } 1963 \\
\text { Willard } 1963\end{array}$ \\
\hline Greenfinch (Chloris chloris) & Adult & 600 & Kushniruk 1964 \\
\hline European Goldfinch (Carduelis carduelis) & Adult & 600 & Kushniruk 1964 \\
\hline Linnet (Acantis cannabina) & Adult & 400 & Kushniruk 1964 \\
\hline House Sparrow (Passer domesticus) & Adult & 625 & Kushniruk 1964 \\
\hline Serin (Serinus canrius) & Adult & 500 & Kushniruk 1964 \\
\hline Weaver Finch (Quelea quelea) & Adult & 1060 & Lofts and Rotblat 1962 \\
\hline Starling (Sturnis vulgaris) & Adult & 800 & Garg et al. 1964 \\
\hline
\end{tabular}

(a) LD50 for duration of nestling exposure to time of fledgling, i.e., 15 to 20 days.

1958). Testicular damage and arrested germ cell maturation were induced by radiation doses equal to, or in excess of, $420 \mathrm{R}$ in weaver finches (Lofts and Rotblat 1962). Feather development was inhibited in nestling bluebirds irradiated at 2 days of age with $43 \mathrm{R} / \mathrm{min}$ for an accumulated dose of 300 to $500 \mathrm{R}$. Nestling growth was reduced by $50 \%$ when exposures reached 1500 to $2000 \mathrm{R}$. When birds receiving 800 to $900 \mathrm{R}$ fledged, they were weak and unable to sustain flight, rendering them more vulnerable to predation (Willard 1960). No observable adverse effects to avian reproduction occurred from a chronic dose of 330 R/30-day nesting period (Wagner and Marples 1966). In the bird communities near a 10-megawatt, air-shielded nuclear reactor close to Marietta, Georgia, the number of singing (territorial) birds declined significantly compared to controls (Schnell 1964). Doses associated with the bird declines ranged from 310 rads for bobwhite (Colinus virginianus) to 27,700 rads in the white-eyed vireo (Vireo griseus). Radiation doses of $160 \mathrm{rad}$ or more to tree swallows' (Iridoprocne bicolor) eggs prolonged incubation, depressed subsequent growth (body mass and foot and primary-feather lengths), and delayed primary-feather emergence (Zach and Mayoh 1986a). Data from chick embryo studies indicate that this radiation-induced stunting is likely to be permanent (Muller and Morenz 1966; Tyler et al. 1967). Chronic exposure to 100 rad resulted in far more severe growth depression of nestling passerines than single doses of 320 rad (Zach and Mayoh 1982; Zach and Mayoh 1986a; Guthrie and Dugle 1983). Gross congenital abnormalities induced by radiation are relatively uncommon in birds. Mraz (1971) found no increase in abnormalities in chicken embryos or resulting chicks from exposure to $15.5 \mathrm{~Gy}$. Phillips and Coggle (1988) reported increased foot and limb deformities in gull chicks only after embryonic exposure to $9.6 \mathrm{~Gy}$. 


\subsection{Bioconcentration Factors and Transfer Coefficients}

There appears to be a discrimination against the movement of radionuclides of high atomic number from lower to higher trophic levels.

\subsubsection{Radionuclide Transfer in Aquatic Systems}

Aquatic invertebrates lose up to half of their body burden of adsorbed and absorbed radionuclides at each molt. Therefore, the total accumulation over their entire life-cycle is reduced. (Wilhm 1970).

\subsubsection{Radionuclide Transfer in Terrestrial Systems}

The radionuclide transfer in terrestrial systems is described below.

\section{Birds}

Food source, behavior, and habitat influence the accumulation of radionuclides in bird tissues. For example, a survey of birds for gross beta activity from a high-mountain watershed (world-wide fallout monitoring) showed that birds that spent a large amount of time feeding and probing for food on the ground had a higher $(217 \mathrm{pCi} / \mathrm{g}$ ) radioactivity level for skin and feathers than raptors (30 pCi/g) (Osbum 1968). Piscivorous (fish-eating) birds had low body burdens of radioactivity compared to those species dependent on insect larvae and vegetation (Krumholz and Rust 1954; Silker 1958). Migratory waterfowl feeding in a radioactive waste impoundment had body burdens of greater than $5 \mu \mathrm{Ci}$ of radioactivity, whereas tissues of herons and kingfishers accumulated very little radioactivity (Krumholz 1964). After the impoundment was drained, carnivorous and omnivorous birds were contaminated throughout the food web via insects and herbivorous species were contaminated by ingestion of soil while searching for seed (Willard 1960). Silker (1958) found that shorebirds and dabbling ducks contained 13 times the amount of strontium-90 found in fish-eating birds associated with Hanford Site operations. Concentration factors for beta-emitters were determined for ducks, shorebirds, grebes, and gulls inhabiting the Columbia River adjacent to the Hanford Site from 1956 to 1959 (Hanson and Watson 1960). These values are listed in Table 2.4. Note that the shorebirds and grebes (larvae consumers), and canvasbacks (herbivores) have much higher concentration factors than the fish-eating or omnivorous birds. 
Table 2.4. Concentration Factors of Beta Emitters in Birds Using the Columbia River in the Vicinity of the Hanford Site, 1956-1959 (Hanson and Watson 1960)

\begin{tabular}{|c|c|c|}
\hline Bird Group & $\begin{array}{l}\text { Consumer } \\
\text { Type }\end{array}$ & $\begin{array}{l}\text { Concentration Factor } \\
\text { [bird weight }(\mathrm{g}) / \text { water }(\mathrm{mL})]\end{array}$ \\
\hline Shorebirds & Larvae feeding & 45 \\
\hline Diving Ducks (Canvasbacks) & Herbivore & 30 \\
\hline Grebes & Larvae feeding & 20 \\
\hline Gulls & Omnivore & 7 \\
\hline Mergansers & Fish-eating & 6 \\
\hline River Ducks & Fish-eating & 1 \\
\hline
\end{tabular}




\subsection{Uranium}

\subsection{Uranium Toxicity}

Uranium emits alpha particles and, as such, does not constitute an extemal radiation hazard. However, the health effects of internal alpha emission in biota can be significant. In addition, uranium has a chemical toxicity unrelated to radioactivity.

\subsubsection{Uranium Toxicity in Aquatic Biota}

Generally, uranium is more toxic to aquatic biota in soft water than in hard water.

\section{Aquatic Plants}

Uranium inhibits growth of aquatic microflora at about $1.0 \mathrm{mg} / \mathrm{L}$ in freshwater systems and appears to be bactericidal at $100 \mathrm{mg} / \mathrm{L}$ (Gus'Kova et al. 1966). These effects are attributed to the chemical rather than radiation toxicity of the uranyl ion. Although severe reductions in diatom survival have been observed for waters containing $1.0 \mathrm{mg} \mathrm{U} / \mathrm{L}$ (Gross and Koczy 1946), other studies have reported abundant diatom populations in waters on uranium mill tailings containing up to $17 \mathrm{mg} \mathrm{U} / \mathrm{L}$ (Ruggles et al. 1979). Cell division was inhibited at $22 \mathrm{mg} / \mathrm{L}$ in the alga, Scenedesmus (Bringman and Kuhn 1959).

The threshold-effect level (inhibition of food intake) of uranium as uranyl acetate has been reported to be $28 \mathrm{mg} / \mathrm{L}$ for the protozoan, Microregma (Bringman and Kuhn 1959).

\section{Invertebrates}

Freshwater hydrae (Hydra viridissima) are highly sensitive to uranium contamination. In studies conducted at the retention ponds for the Ranger Uranium Mines in tropical Northem Australia, rapid lysis of the hydrae was observed within $48 \mathrm{hr}$ of exposure to greater than $1 \mathrm{mg} / \mathrm{L}$ uranium (Hyne et al. 1991). Lower concentrations $(150 \mu \mathrm{g} / \mathrm{L})$ significantly inhibited growth of asexuallyreproducing hydrae after 3 to 4 days of culture (Hyne et al. 1991). Hyne et al. (1992) demonstrated that populations of hydrae exposed to greater than $200 \mu \mathrm{g} / \mathrm{L}$ uranium for 3 days suffered a reduction in population growth of about 50\%. Concomitant with the population decrease was a reduced ability to capture live prey. Transmission electron microscopy and energy dispersive $\mathrm{X}$-ray microanalysis (EDAX) indicated that the feeding dysfunction and reduced population growth were correlated with a pathological accumulation of uranium in nematocysts. Because of its sensitive, uranium-specific endpoint, this assay could be used to distinguish between environmental effects that are caused by uranium and those that result from other pollutants or environmental conditions. The acute toxicity of 
uranium to cladocerans varies with water quality, particularly total hardness and alkalinity (Poston et al. 1974). The concentrations killing $50 \%$ of exposed organisms (LC50s) of uranium in cladoceran species are listed in Table 3.1.

Table 3.1. Acute Toxicity of Uranium in Aquatic Invertebrates (Cladoceran Species)

\begin{tabular}{|c|c|c|c|c|}
\hline Species & $\begin{array}{l}\text { Water Hardness } \\
\text { (mg } \mathrm{CaCO}_{3}(\mathrm{~L})\end{array}$ & $\begin{array}{r}\text { LC50 } \\
(\mathrm{mg} / \mathrm{L})\end{array}$ & Duration of Test & Reference \\
\hline \multicolumn{5}{|l|}{ Northern Hemisphere } \\
\hline Daphnia magna & 70 & 6.5 & $48 \mathrm{~h}$ & Poston et al. 1984 \\
\hline Daphnia magna & 133 & 37.5 & $48 \mathrm{~h}$ & Poston et al. 1984 \\
\hline Daphnia magna & 197 & 52.5 & $48 \mathrm{~h}$ & Poston et al. 1984 \\
\hline \multicolumn{5}{|l|}{ Tropical } \\
\hline Diaphanosoma excisum & 5 & 1.0 & $24 \mathrm{~h}$ & Bywater et al. 1991 \\
\hline Latonopsis fasciculata & 5 & 0.4 & $24 \mathrm{~h}$ & Bywater et al. 1991 \\
\hline Daeaya macrops & 5 & 1.1 & $24 \mathrm{~h}$ & Bywater et al. 1991 \\
\hline Moinodaphnia macleayi & 5 & 1.3 & $24 \mathrm{~h}$ & Bywater et al. 1991 \\
\hline
\end{tabular}

Fish

As with the cladocerans, the toxicity of uranium to fish varies markedly with water conditions. The 96-h LC50 of uranium (as $\mathrm{UO}^{2+2}$ ) in fathead minnows is $3 \mathrm{mg} / \mathrm{L}$ in waters with $\mathrm{pH} 7.4$ and hardness of $210 \mathrm{mg} / \mathrm{L}$. In waters of $\mathrm{pH} 8.2$ and a hardness of $400 \mathrm{mg} / \mathrm{L}$, the $96-\mathrm{h} \mathrm{LC50}$ is $135 \mathrm{mg} / \mathrm{L}$ (McKee and Wolf 1963). However, when water conditions are similar, differences in both intraspecific and interspecific toxicities are negligible (Bywater 1991). LC50 data for various tropical and Northern Hemisphere freshwater fish are compiled in Table 3.2. To provide a predictive tool of uranium toxicity for freshwater fish in various waterbodies, least-squares linear regression was used to test the relationship between the 48-h LC50 values compiled from the literature and the total hardness (expressed as mg-equivalent $\mathrm{CaCO}_{3} / \mathrm{L}$ ) of the test water used to establish the LC50. As shown in Figure 3.1, the relationship between the 96-h LC50 and water hardness is linear.

Little information is available on sublethal- or threshold-effect levels of uranium in fish species. Laboratory tests have shown that the hatchability of carp eggs (Cyprinus carpio) is not affected by $60 \mathrm{mg} / \mathrm{L}$ uranium in areas of high water hardness (Till and Blaylock 1976). Parkhurst et al. (1984) reported a no observable effect concentration (NOEC) of gre wer than $9.0 \mathrm{mg} / \mathrm{L}$ for uranium in brook 
Table 3.2. Acute Toxicity of Uranium to Freshwater Fish. LC50 values are for 96-H exposures.

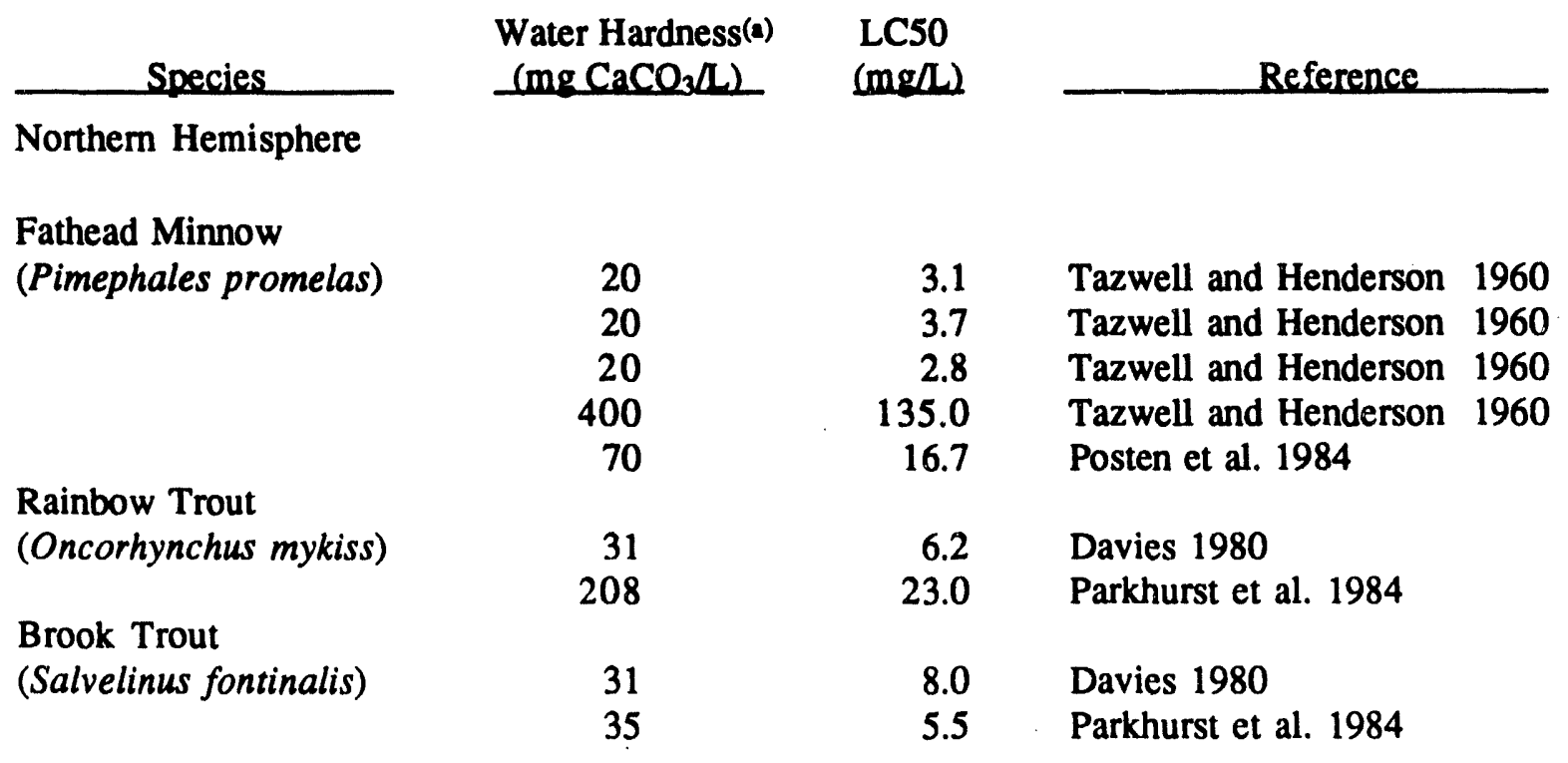

Tropical

$\begin{array}{lrrl}\text { Hypseleotris. compressa } & 10 & 6.6 & \text { Skidmore and Firth } 1983 \\ \text { Melanotaenia nigras } & 5 & 2.1 & \text { Bywater et al. 1991 } \\ & 5 & 2.4 & \text { Bywater et al. 1991 } \\ \text { Melanotaenia splendida } & 10 & 4.5 & \text { Skidmore and Firth 1983 } \\ & 5 & 2.8 & \text { Bywater et al. 1991 } \\ \text { Melanotaenia s. inornata } & 5 & 3.8 & \text { Bywater et al. 1991 } \\ & 10 & 6.0 & \text { Skidmore and Firth 1983 } \\ \text { Craterocephalus marianae } & 5 & 1.4 & \text { Holdway 1992 } \\ & 10 & 1.8 & \text { Bywater et al. 1991 } \\ \text { Amniataba percoides } & 10 & 4.3 & \text { Giles 1964 } \\ \text { Leiopotherapon unicolor } & 10 & 25.0 & \text { Giles 1964 } \\ \text { Pseudomugil tenellus } & 5 & 4.1 & \text { Giles 1964 } \\ \text { Ambassis macleayi } & 5 & 0.8 & \text { Bywater et al. 1991 } \\ \text { Mogurnda mogurnda } & 5 & 0.8 & \text { Bywater et al. 1991 } \\ & 5 & 2.1 & \text { Bywater et al. 1991 } \\ & & 2.2 & \text { Bywater et al. 1991 } \\ & & 1.6 & \text { Holdway 1992 } \\ & & 3.2 & \text { Holdway 1992 } \\ & & 3.3 & \text { Holdway 1992 }\end{array}$

(a) When not reported directly, hardness was calculated from the concentration of calcium and magnesium in the water by the equation: Hardness $=2.497$ [calcium] +4.118 [magnesium] as $\mathrm{mg}$ equivalents of $\mathrm{CaCO}_{3}$ (APHA 1980). 


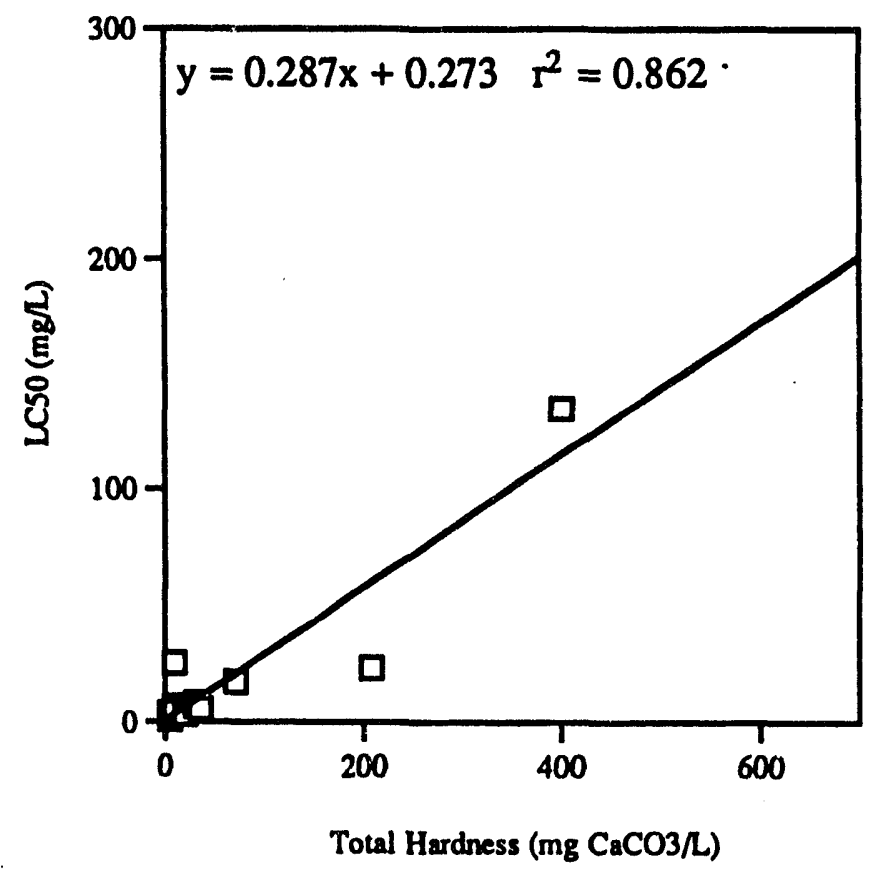

Figure 3.1. Relationship Between Acute Toxicity of Uranium to Freshwater Fish and the Total Hardness of the Test Water. Toxicity is expressed as the 96-h LC50. Data are obtained from references listed in Table 3.2.

trout embryos and larvae. An NOEC of less than $404 \mu \mathrm{g} / \mathrm{L}$ was determined for gudgeon larvae (Mogurnda mogurnda) above which body length and weight were affected (Holdway 1992). The calculated threshold response for the most sensitive response (growth) in tropical fish was $200 \mu \mathrm{g} / \mathrm{L}$

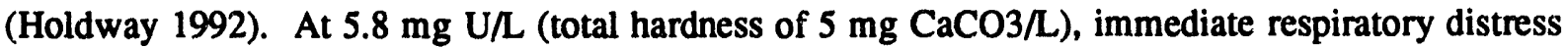
was observed in adults of eight fish species (Bywater et al. 1991). Chronic exposure to elevated radionuclide levels from uranium mine tailings in Langley Bay, Lake Athabasca, Saskatchewan, Canada, did not affect hematocrit, histological characteristics of radiosensitive tissues, rate of parasitism, or growth of whitefish (Coregonus clupeaformis) and northern pike (Esox lucius). Exposure levels to uranium-series radionuclides in this study were $27 \mu \mathrm{g} / \mathrm{g}$ uranium, $453 \mathrm{pCi} / \mathrm{g}$ radium-226, $700 \mathrm{pCi} / \mathrm{g}$ lead-210, and $6 \mathrm{pCi} / \mathrm{g}$ thorium-228 in the sediment (dry weight).

\subsubsection{Uranium Toxicity in Terrestrial Biota}

The uranium toxicity in terrestrial biota, including plants, invertebrates, and mammals is described in the following section. 


\section{Plants}

Four-week-old soybean plants (Glycine max [L.] Merr.) grown hydroponically were adversely affected by uranium at concentrations of $0.42 \mu \mathrm{g} / \mathrm{mL}$ and above (Murthy et al. 1984). Chlorosis, early leaf abscission, and reduction in root growth were the toxic symptoms induced by uranium. At $42 \mathrm{mg} / \mathrm{L}$ of uranium, widespread tissue necrosis was observed, and total leaf chlorophyll content was reduced by $30 \%$ to $40 \%$. These symptoms were probably caused by reduced root absorption capacity and dysfunction of xylem and phloem tissue from uranium precipitation (Cannon 1960). Uranium concentrations in the roots of the affected soybean plants were $57 \mu \mathrm{g} / \mathrm{g}$ dry weight $( \pm 2.90)$ and $938 \mu \mathrm{g} / \mathrm{g}$ dry weight $( \pm 22.6)$ in the $0.42-$ and $42-\mu \mathrm{g} / \mathrm{mL}$-treated plants, respectively. Shoot concentrations were $1.37 \mu \mathrm{g} / \mathrm{g}$ for the $0.42-\mu \mathrm{g} / \mathrm{mL}$-treated plants and $91.5 \mu \mathrm{g} / \mathrm{g}$ for plants grown in the $42-\mu \mathrm{g} / \mathrm{mL}$ uranium solutions.

In soil-grown plants, overt effects on growth and survival were not seen below $1000 \mathrm{mg} \mathrm{U} / \mathrm{kg}$ of soil (Sheppard et al. 1992). However, Sheppard and Evenden (1992) have suggested sublethal toxicity may occur in plants grown in soils containing between 10 to $100 \mathrm{mg} \mathrm{U} / \mathrm{kg}$. In this exposure range, the ability to restrict uranium uptake appears to become impaired.

Uranium inhibited root growth in mature Swiss chard plants at soil concentrations of $10 \mu \mathrm{g} \mathrm{U} / \mathrm{g}$ in both sand and peat soils. Shoot yields were not affected (Sheppard et al. 1983).

\section{Invertebrates}

Earthworm survival was decreased at concentrations of $1000 \mathrm{mg} \mathrm{U} / \mathrm{kg}$ dry soil and greater (Sheppard and Evenden 1992). Stewart et al. (1992) evaluated the downstream effects of drifted aquatic pond weeds and filamentous algae that originated in an impoundment near the U.S. Department of Energy's (DOE's) Y-12 Plant in Oak Ridge, Tennessee, on aquatic snails (Elimia clavaeformis) and amphipods (Grammarus sp.). The vegetation was contaminated with uranium, several heavy metals including chromium and cobalt, and poly-chlorinated biphenyls. In laboratory and instream feeding trials, the snails and amphipods distinguished between contaminated and noncontaminated pond weeds, generally avoiding the contaminated vegetation. The snails had lower growth rates on the contaminated plants. However, because of the presence of other contaminating chemicals in the vegetation, it cannot be concluded that uranium was responsible for the avoidance behavior and lowered growth rates of associated invertebrates.

\section{Amphibians/Reptiles}

No studies were found on the chemical or radiation toxicity of uranium in amphibians or reptiles. 


\section{Mammals}

Sensitivity to uranium varies among mammal species. Rabbits, dogs, and guinea pigs are more sensitive to uranium exposure than rats by factors of 2 to 10, with rabbits being the most susceptible to uranium toxicity (Leach et al. 1984; Morrow et al. 1982; Morrow et al. 1981). Solubility of the uranium compounds governs their toxicity. The soluble hexavalent compounds are considerably more toxic than the less soluble tetravalent uranium compounds (Venugopal and Luckey 1978; Haven and Hodge 1949). The impact of uranium exposure on the animals is dependent not only on the dose and chemical form of uranium, but also on the route of exposure.

Toxic Response from Oral Exposure. The lowest oral LD50 value reported for mammals is $5.7 \mathrm{mg} / \mathrm{kg}$ in dogs exposed to uranium as uranyl nitrate hexahydrate [UO2(NO3)2.6H2O]. The oral LD50s for rats and mice are $115 \mathrm{mg} / \mathrm{kg}$ and $136 \mathrm{mg} / \mathrm{kg}$ [uranium as UO2AC·2(H20)], respectively (Domingo et al. 1987). Threshold concentrations causing slight malaise in domestic livestock are $50 \mathrm{mg} / \mathrm{d}$ in sheep and $400 \mathrm{mg} / \mathrm{d}$ in dairy cattle (Gamer 1963). The levels NOAELs for rodents are $11 \mathrm{mg} / \mathrm{kg}$ in rats and $25 \mathrm{mg} / \mathrm{kg}$ in mice. The lowest observable adverse effect level (LOAEL) for systemic, sublethal effects in rats is $118 \mathrm{mg} \mathrm{U} / \mathrm{kg}$. Adverse effects include hepatic lesions, proteinuria, and weight loss (Domingo et al. 1987). Based on a long-term feeding study, an NOAEL for uranium in dogs of $1 \mathrm{mg} / \mathrm{kg}$ body weight/d has been estimated (Bosshard et al. 1992).

In prolonged feeding studies (Maynard and Hodge 1949; Maynard et al. 1953; Tannenbaum and Silverstone 1951), soluble compounds such as uranyl nitrate hexahydrate, uranium peroxide, uranyl acetate dihydrate, and uranyl fluoride were lethal at lower levels than insoluble uranium compounds such as uranium dioxide and uranium tetrafluoride. For example, when uranyl nitrate hexahydrate [ $\mathrm{UO}_{2}\left(\mathrm{NO}_{3}\right) 2 \cdot 6 \mathrm{H}_{2} \mathrm{O}$ ] was incorporated in the food, the NOAEL was $24 \mathrm{mg} / \mathrm{kg} / \mathrm{d}$ (1 year) for rats. Renal necrosis occurred at $118 \mathrm{mg} / \mathrm{kg} / \mathrm{d}$ and testicular pathology was observed at $474 \mathrm{mg} \mathrm{U} / \mathrm{kg} / \mathrm{d}$ (Maynard et al. 1953). However, no effects were observed in rats fed over $7500 \mathrm{mg} \mathrm{U} / \mathrm{kg} / \mathrm{d}$ in the form of uranium dioxide or uranium tetrafluoride for 2 years (Maynard and Hodge 1949; Maynard et al. 1953). In rabbits, no adverse effects from 30 days of uranyl nitrate hexahydrate at $4.6 \mathrm{mg} / \mathrm{kg} / \mathrm{d}$ were observed, but levels of 469 ppm uranium in food resulted in death (Maynard and Hodge 1949). A summary of LOAELs for chronic oral exposures to uranium is presented in Table 3.3.

Toxic Response from Inhalation Exposure. Deaths from acute and chronic exposures to uranium compounds result from the chemical, not the radiological, effects of uranium and are attributed to renal toxicity (Leach et al 1984). Acute LC50s in small mammals range from 12,000 to $120,000 \mathrm{mg} / \mathrm{m} 3$ for exposures of less than 10 minutes in duration. A 60 -minute exposure to uranium hexafluoride resulted in $100 \%$ mortality in rats exposed to $2160 \mathrm{mg} / \mathrm{m} 3$ of the compound (Leach et al. 1984). Chronic exposures (6.5 to 13 months) of rats, rabbits, guinea pigs, and dogs to aerosols of various uranium compounds resulted in kidney damage, blood abnormalities, and death. These data are summarized in Table 3.4 . 
Table 3.3. Lowest Concentrations of Uranium in Food and Drinking Water Causing Adverse Health Effects in Mammals (ATSDR 1990a)

\begin{tabular}{|c|c|c|}
\hline Concentration (ppm) & Exposure Duration & Effect \\
\hline Food & & \\
\hline 9480 & 1 dose & Rats had fewer pups \\
\hline 94 & 30 days & Kidney damage in rabbits \\
\hline 469 & 30 days & Death in rabbits \\
\hline 1940 & 2 years & Death in rats \\
\hline 2315 & 48 weeks & Death in mice \\
\hline
\end{tabular}

Water

16

16

21

64

471
Days 6-15 of gestation

8-14 weeks during gestation and after pregnancy

Day 13 of gestation to day 21 of nursing

4 weeks

4 months
Weight loss in mothers

Deformities in pups

Decreased pup weight in mice

Maternal death in mice

Kidney, liver, blood effects in rats

Damage to testes in rats

Table 3.4. Lowest Concentrations of Airborne Uranium Causing Adverse Health Effects in Mammals (Stokinger et al. 1953)

Airborne Uranium $\left(\mathrm{mg} / \mathrm{m}^{3}\right)$

0.05

0.20

0.25

0.25
Exposure Duration

1 year

7.5 months

6.5 months

1 year
Effect

Slight kidney injury in rats

Kidney damage in guinea pigs

Kidney damage and death in rabbits

Kidney damage and death in dogs

Toxic Response from Dermal Exposure. Orcutt (1949) reported dermal LC50s for uranyl nitrate applied to various mammal species. These values were $59 \mathrm{mg} \mathrm{U} / \mathrm{kg}$ in rabbits, $2110 \mathrm{mg} / \mathrm{kg}$ in guinea pigs, $490 \mathrm{mg} / \mathrm{kg}$ in rats, and $7600 \mathrm{mg} / \mathrm{kg}$ in mice. Soluble uranium compounds (uranyl nitrate hexahydrate, uranyl fluoride, uranium pentachloride) were toxic when applied dermally to rabbits. The slightly soluble compounds (uranium trioxide, sodium diuranate, ammonium diuranate) were much less toxic, and the insoluble compounds (uranium dioxide, uranium tetrafluoride) were 
nontoxic to rabbits (Orcutt 1949). Table 3.5 summarizes the dermal LOAEL observed for soluble and slightly soluble uranium compounds in rabbits.

Immunological Effects of Uranium Exposure. No studies have been reported on immunological effects of uranium exposure through the dermal route. Chronic oral (Stokinger et al. 1953) and inhalation (Maynard and Hodge 1949; Maynard et al. 1953; Tannenbaum and Silverstone 1951) exposures of rats, rabbits, guinea pigs, and dogs to various uranium compounds did not result in any significant histological changes in the lymph nodes, bone marrow, or spleen. An indication of an immune response to uranium exposure was noted in rats exposed to ammonium diuranate (Galibin et al. 1966). The exposed rats showed an increase in mouth microflora and in the phagocytic activity of neutrophils. Although the tracheobronchial lymph nodes of dogs exposed to uranium dioxide for greater than 3 years had areas of necrosis and fibrosis and were high in alpha radiation activity, there was no loss of circulating lymphocytes. This finding indicated that the immunological system was not functionally damaged (Leach et al. 1970). Rabbits given greater than 0.05 to $5 \mathrm{mg} \mathrm{U/L}$ drinking water for 6 months showed decreased antibody production and impaired resistance to infection (Novikov and Yudina 1970).

Reproductive Effects of Uranium Exposure. Pregnant mice exposed to $3 \mathrm{mg} \mathrm{U} / \mathrm{kg}$ in their water (i.e., $16 \mathrm{mg} / \mathrm{L}$ ) during days 6 through 15 of gestation showed decreased body weight and produced stunted fetuses with skeletal malformations (Domingo et al. 1989a). The reported NOAEL for pregnant mice is $0.3 \mathrm{mg} / \mathrm{kg} / \mathrm{d}$ (Domingo et al. 1989b). Exposure to $6 \mathrm{mg} \mathrm{U} / \mathrm{kg} / \mathrm{d}$ for 4 to 8 weeks resulted in a serious decrease in pup viability (Paternain et al. 1989). A significant increase in total and late resorptions was observed in mice orally gavaged with $14 \mathrm{mg}$ uranium (as uranyl acetate dihydrate)/ $\mathrm{kg} / \mathrm{d}$ for 4 to 8 weeks (Patemain et al. 1989).

Degenerative changes in the testes of rats have resulted from chronic oral exposure to uranium compounds. Administration of uranyl nitrate hexahydrate in the diet for 1 year produced testicular lesions at $474 \mathrm{mg} \mathrm{U} / \mathrm{kg} / \mathrm{d}$ (Maynard et al. 1953); administration of this compound via water for

Table 3.5. Lowest Concentrations of Uranium that Caused Adverse Health Effects when Applied to the Skin of Rabbits (Orcutt 1949).

\section{LOAEL} (mg U/kg/d)

267

267 6.7

64 5

\begin{tabular}{l} 
Compound \\
\hline Uranium trioxide \\
Sodium diuranate \\
Uranyl nitrate hexahydrate \\
Uranyl nitrate hexahydrate \\
Uranyl nitrate hexahydrate
\end{tabular}

Exposure Duration
1 day $(4 \mathrm{~h} / \mathrm{d})$
1 day $(4 \mathrm{~h} / \mathrm{d})$
1 day $(4 \mathrm{~h} / \mathrm{d})$
1 day $(4 \mathrm{~h} / \mathrm{d})$
5 weeks $(5 \mathrm{~d} / \mathrm{wk})$

Effect

Proteinuria

Proteinuria

Proteinuria

Weight loss

Death 
4 months resulted in testicular histopathology at $66 \mathrm{mg} \mathrm{U} / \mathrm{kg} / \mathrm{d}$ (Malenchenko et al. 1978). Testicular atrophy was produced in rats after 2 years of exposure to $97 \mathrm{mg}$ uranium (as uranyl fluoride)/kg/d (Maynard and Hodge 1949; Maynard et al. 1953). Exposure to $80 \mathrm{mg} / \mathrm{kg} / \mathrm{d}$ uranyl acetate dihydrate via drinking water for 64 days resulted in significant histopathological changes in the testes of rats (Llobet et al. 1991). Although testicular function and spermatogenesis were not affected at this or lower concentrations, the uranium exposure produced a significant decrease in the pregnancy rate at $10,20,40$, and $80 \mathrm{mg} / \mathrm{kg} / \mathrm{d}$, probably as a consequence of reduced spermatozoa counts.

Carcinogenic Effects of Uranium Exposure. No animal tests have been conducted to study cancer incidence following oral exposure to uranium. Although non-neoplastic kidney damage has been observed in numerous feeding studies, no tumors in any organs have been observed during these tests. Inhalation exposures with a calculated radiation dose to the lungs of dogs of $600 \mathrm{rad}$ resulted in neoplastic changes in the lung tissue (Leach et al. 1973). It should be noted that exposure to any radioactive substance will potentially cause cancer, and enriched uranium would be expected to present a higher risk for cancer than natural uranium. Bone-sceking, alpha-emitting radionuclides such as radium-226 may give rise to tumors, particularly bone sarcomas (Rowland et al, 1978). Fatal cancer risk in humans from uranium exposure has been inferred from data on skeletal cancer induction by radium isotopes (Mays et al. 1985).

Genotoxicity. No studies have been conducted on the genotoxic effects of uranium in animals following oral or inhalation exposure. Chromosome aberrations have been reported for cultured lymphocytes of uranium miners (Brandom et al. 1978).

Biomarkers of Uranium Exposure/Effect. Kidneys, livers, and bones are uranium accumulator organs, although the cardiovascular system and central nervous system may also accumulate uranium. Kidney and bone tissues are the main targets of both the radiation and chemical toxicity of uranium in vertebrate organisms. Of these two tissues, kidney tissue is the most sensitive and is considered to be the key target organ for hazard assessment (Diamond 1989). The characteristic lesion of uranium poisoning in all mammal species studied is injury and necrosis of the terminal segments of the renal proximal tubule. Injury of the glomerulus is also reported for most species (Avasthi et al. 1980; Haley 1982, Haley et al. 1982). In dogs, the acute renal injury threshold appears to be less than $1 \mu \mathrm{g}$ U/g kidney with histopathological changes evident in kidney tissue at organ concentrations greater than or equal to $0.5 \mu \mathrm{g} / \mathrm{g}$ kidney (Hodge et al. 1953). This concentration is also the injury threshold level observed in rats; however, nephrotoxicity resulting from less than or equal to $5 \mu \mathrm{g} \mathrm{U/g}$ kidney is reversible in this species (Morrow et al. 1982; Diamond et al. 1987).

Recently, sensitive biochemical parameters have been used to monitor uranium-induced kidney injury. Measures of B-2-microglobulin, amino acids, glucose, aspartate amino-transferase, and alanine amino-transferase activities in blood have been used to document glucosuria, proteinuria, and 
tubular effects (osmotic dieresis, amino aciduria, and enzymuria) of uranium damage (Leach et al. 1984; Domingo et al. 1989a; Diamond 1989). No one biochemical biomarker has been identified for use in uranium hazard monitoring.

The critical target organ for chronic exposure to uranium is the skeletal system (Adams and Spoor 1974; Guglielmotti et al. 1984). However, skeletal burden/exposure relationships have not been determined for laboratory or wild mammal species.

Fecal and urinary samples may be used to identify or quantify exposure to uranium (ATSDR 1990a). Fecal sampling can provide information on current uptake levels, but gives no information on body burden (Schieferdecker et al. 1985). It is possible, in humans, to use urinary excretion rates to determine body burden (Lippman et al. 1964). However, this approach has not been applied to animals thus far.

Uranium Toxicokinetics: Metabolism and Distribution. Gastrointestinal absorption of soluble uranium compounds in humans appears to range between $0.5 \%$ and $30 \%$ (Hursh and Spoor 1973; Hursh et al. 1969; ICRP 1979; DeRay et al. 1983). An average absorption rate of $5 \%$ is commonly used for uranium risk assessments in humans (ICRP 1979). In animal studies, dogs, rabbits, and hamsters absorbed about $0.5 \%$ to $2 \%$ of the administered uranium dose (Wrenn et al. 1985; Harrison and Stather 1981). Rats absorbed less than $0.1 \%$ (Wrenn et al. 1985; Sullivan 1980). However, if the dose was administered to fasted rats, gastrointestinal absorption increased to $0.6 \%$ to $2.8 \%$ (LaTouche et al. 1987). For the less soluble compounds such as uranium dioxide, gastrointestinal absorption approached $0.2 \%$ (ICRP 1979). Seventy percent to $85 \%$ of the absorbed uranium was rapidly excreted in the urine (Hursh and Spoor 1973; Priest et al. 1982) and less than $1 \%$ in feces (NRCC 1982). About $12 \%$ to $20 \%$ of the absorbed uranium was assumed to be retained in the kidney with a retention half-life of 6 days (Friberg 1977; Adams and Spoor 1974; ICRP 1979). Another 0.5\% to $20 \%$ of the absorbed dose was deposited in the skeleton with a retention half-life of about 1500 days (ICRP 1979; NRCC 1982).

\section{Birds}

No studies were found on the chemical or radiation toxicity of uranium in avian species.

\subsection{Bioconcentration Factors and Trophic Transfer Coefficients}

Uranium, which forms relatively insoluble compounds in the environment and has no known essential biological function, is not biologically mobile. It attaches to surfaces and accumulates in soils and sediments (Schultz and Whicker 1982). Uranium enters the food chain via adsorption on surfaces of plants and small animals. Because of membrane discrimination against uranium, little uranium is accumulated internally in biota. Consequently, concentration factors for uranium decline substantially with trophic level. 


\subsubsection{Uranium Transfer in Aquatic Food Chains}

Reported water-based bioconcentration factors for uranium in fresh water algae include 1576 (Mahon 1982) and 2096 (Stegnar and Kobal 1982). Water bacteria reportedly concentrate uranium by factors of 2794 to 354,200 . It has been suggested that the apparently high bioaccumulation of uranium by algae and bacteria may be due to adsorption of the radionuclide onto cell surfaces rather than actual uptake by the organisms (Atkins 1977; Horikoshi et al. 1981). Maximum accumulation of cell-bound uranium in algae occurs at pH 5.9 to 6.8 (Marvan 1976) and in waters containing low phosphate and carbonate levels (Nakajima et al. 1979). Cell-bound uranium can reach up to $10 \%$ to $15 \%$ of dry cell weight of algae and other micro-organisms (Strandberg et al. 1981).

Thompson et al. (1972) reported a coefficient of 0.55 for uranium transfer from water to aquatic macrophytes. A transfer coefficient from sediment to pond weeds (Potamogeton foliosus) growing in an impoundment near the DOE's Y-12 Plant in Oak Ridge, Tennessee, was 0.0225 (calculated from data presented in Stewart et al. 1992). However, according to the authors, the analytical methods used underestimated uranium concentrations. Therefore, the bioconcentration factor reported for the pond weed was likely underestimated. Using the reported water concentration and the levels of uranium found in pond weeds from a lake receiving uranium mine tailings in Saskatchewan, Canada, a bioconcentration factor of 1.13 can be calculated for Potamogeton species and a factor of 1.5 determined for Myriophyllum species. Sediment-to-plant transfer coefficients for the pond weeds were 0.16 and 0.20 for Potamogenoton and Myriophyllum species, respectively (Waite et al. 1988).

Accumulation of uranium in plankton was 459 times that of the water concentration, and bioconcentration factors of 306 for mollusca (Pisidium) and 14.7 for fish (Oncorhynchus mykiss and Catastomus catastomus) were reported for the aquatic food chain described by Mahon (1982). Thompson et al. (1972) reported a bioconcentration value of 60 for both mollusca and crustacea and a value of 2 for fish in aquatic systems exposed to uranium. In general, water-to-invertebrate transfer coefficients for uranium are more variable than those reported for fish, probably because of the greater variation in trophic and spatial niches among invertebrates (Swanson 1985). Reported waterto-invertebrate transfer coefficients ranged from 1 to 10,000 . However, the majority of the coefficients fall between 100 and 1000 (Anderson et al. 1963; EPS 1978, Gulf Minerals Canada 1980; Mahon 1982; OWRC 1971; Reichle et al. 1970a, 1970b; Thompson et al. 1972; Van der Borght 1963; Swanson 1985). The highest reported bioconcentration factors for uranium in rainbow trout (Oncorhynchus mykiss), suckers (Castastomus catactomus), and lake whitefish (C. clupeaformis) did not exceed 38 (Mahon 1982; Poston 1982; Swanson 1985). Eyed carp eggs accumulated uranium in the yolk material and concentrated the radionuclide by a factor of 3.3 from water (Till and Blaylock 1976). Bioconcentration factors for uranium in brook trout eggs and fry ranged from 1.9 to 4.3 in hard water $\left(210 \mathrm{mg} / \mathrm{L}\right.$ as $\left.\mathrm{CaCO}_{3}\right)$ (Parkhurst et al. 1984). Although transfer coefficients from water to fish ranged from 1 to 650 (Anderson et al. 1963; EPS 1978; Gulf Minerals Canada 1980; OWRC 1971; Thompson et al. 1972; NRC 1977; Key Lake Mining 1979; Cluff Mining 1979; Parkhurst et al. 1984; Waite et al. 1988; Swanson 1985), the assimilation efficiency for uranium in fish in most 
studies was low, with transfer coefficients less than 50. In the absence of site-specific data, recommended default values for the water-based bioconcentration factor for uranium in the flesh of freshwater fish are 10 (NRCC 1983), 20 for fish-eating and plankton feeding fish in water of low mineral content and 2 for fish in water of high mineral content (CSA 1987). A conservative default biocentration factor for bottom-feeding fish is 50 (Poston and Klopfer 1986; Myers 1989).

Sediments act as a sink for uranium with the concentration of uranium in the sediments and suspended solids several orders of magnitude higher than the concentration in water. Transport of uranium from water to organisms occurs primarily through the sediment (Brunskill and Wilkinson 1987; Swanson 1985). However, few data are available on sediment-to-organism transfer of radionuclides. In a study of the transfer pathways and effects of uranium-series radionuclides in a stream and a lake receiving contaminated drainage from uranium mill tailings, organisms feeding on or near sediments were found to contain higher levels of uranium than pelagic or predatory species (Swanson 1985). Bottom feeders such as midge larvae (Chironomous sp.) and caddisfly larvae (Nemotaulius sp.) had uranium concentrations of $15 \mu \mathrm{g} / \mathrm{g}$ and $26 \mu \mathrm{g} / \mathrm{g}$, respectively, compared to $5 \mu \mathrm{g} / \mathrm{g}$ for the predatory dragonfly nymphs. Sediment-to-insect transfer coefficients ranged from 0.1 to 0.3 in this study. Concentration of uranium from insects to forage fish varied between 0.08 for caddisfly larvae transfer to lake chub (Couesius plumbeus) and 1.3 for blackfly uranium transfer to small white sucker (Catostomus commersoni). Transfer coefficients from forage fish to large white fish were 0.04 (flesh) and 0.98 (skin). Overall sediment-to-fish transfer coefficients ranged from 0.02 to 0.05 . Water-to-fish coefficients were 5.7 to 11.0 (Swanson 1985).

In general, there is a decline of about one order of magnitude in the bioconcentration factor at each step in the aquatic food chain (Mahon 1982; Blaylock and Witherspoon 1978; Kovalsky et al. 1967; Thompson et al. 1972; Swanson 1985). Thus, no biomagnification of uranium from the aquatic or semi-aquatic (amphibian, waterfowl, and mammal) food chain is expected.

\subsubsection{Uranium Transfer Through Terrestrial Food Chains}

Transport of uranium from soil to biota has been documented (Dreesen et al. 1982; Moffett and Tellier 1977; Mahon 1982). It has been assumed that the nature of the soil determines the amount of bioavailable uranium. For example, soil conditions that favor decreased sorption or formation of soluble complexes with uranium will enhance uptake. Swiss chard grown in sandy soils contained 80 times higher concentrations of uranium than chard grown in peat (Sheppard et al. 1983). However, in a study of the effect of 11 different soil types on bioavailability indices for uranium (Sheppard and Evenden 1992), no correlation between plant or invertebrate uptake and soil parameters was observed. The soils were treated with up to $10,000 \mathrm{mg} \mathrm{U} / \mathrm{kg}$ soil and varied with regard to texture, clay, organic content, pH, background uranium content, and cation exchange capacity. Uranium concentrations in plants and earthworms were not linearly related to uranium concentrations in the soil. Thus, a single value for use as a conservative concentration ratio for a soil type could not be determined, and the implication is that other reported concentration ratios for uranium in plants 
should not be applied to soil concentrations outside those for which the concentration ratio was determined. Concentration ratios in plants and earthworms associated with the soil types are summarized in Table 3.6.

Uranium appears to be restricted to the root system of plants and may be precipitated on the outer root membrane rather than accumulated in the interior of the root (Sheppard 1985). Little uranium enters the root sap system (Robards and Robb 1972), and virtually no uranium is translocated from the soil to the above-ground plant tissue (Sheppard 1983; Van Netten and Morley 1983). Several concentration ratios have been reported for shoots, leaves, fruits and seeds (the "edible") portions of plants, but all of these ratios were less than 1 . $\mathrm{Ng}$ et al. (1982) reported uranium concentration ratios for edible portions of food crops (wet plant/dry soil) from $1.7 \times 10^{-7}$ to $2.0 \times 10^{-2}$. The range of concentration ratios for the edible portions of pasture plants was $1.6 \times 10^{-6}$ to $8.5 \times 10^{-1}$ ( $\mathrm{Ng}$ et al. 1982). Garten et al. (1987) reported concentrations factors for plants grown in a contaminated flood plain as $9.3 \times 10-1$ for leaves and stems of standing crops, $9.2 \times 10-2$ for fruit and vegetables, $6 \times 10-2$ for fescue, and $7 \times 10-2$ for tree leaves. Concentration ratios greater than one appear to be associated with dusty conditions (Garten et al. 1987).

Mahon (1982) studied the trophic transfer of uranium in several wildlife food chains. For the terrestrial food chains studied, there was a drop in body burden of uranium by one order of magnitude for each trophic level (Mahon 1982). The transfer coefficient from vegetation [grouseberry forb (Vaccinium scoparium), lichens (Bryoria freemontia and Alectoria sarmentosa), and grass (Calamagrostis rubescens)] to deer (Odocoileus hemionus) was 0.7. Bioconcentration ratios for chipmunks (Eutamius amoenus) and herbivorous mice feeding on fireweed seed heads (Epilobium angustifolium) and grouseberry were 0.5 and 0.26 , respectively. The top predator in this food chain was an avian predator, the raven (Corvus corvus), which was found to have less than $5 \mathrm{ppb}$ uranium in its tissues. Similar uranium food chain transfers were seen in domestic animal foragers. Transfer coefficients from soil surface layer $(0$ to $30 \mathrm{~cm})$ to forage grass ranged from $2.67 \times 10^{-5}$ to $2.98 \times 10^{-4}$. Forage grass-to-sheep transfer coefficients were $2.5 \times 10^{-5}$ to $2.4 \times 10^{-4}$ in meat.

It should be noted that uranium uptake from water consumption was not addressed in these studies, nor were root-consuming organisms even though roots appear to be a significant source of exposure (Van Netten and Morley 1983). 
Table 3.6. Accumulation of Uranium in Plant and Soil Invertebrates as Related to Soil Type (Sheppard and Evenden 1992)

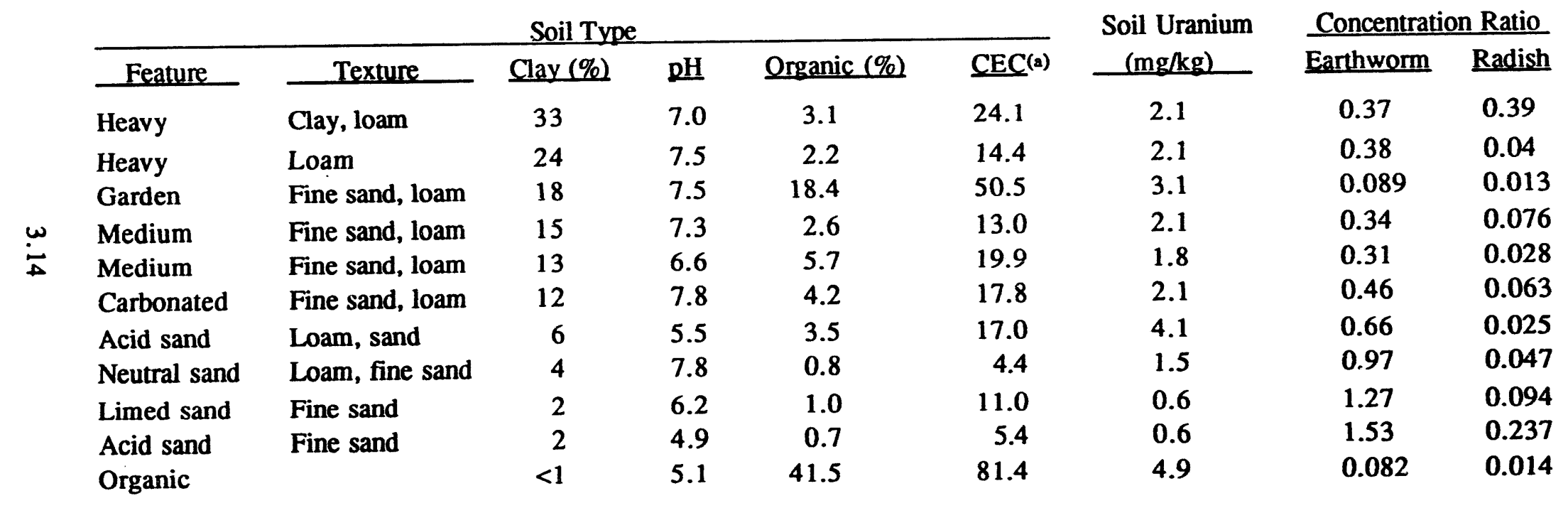

(a) Cation Exchange Capacity $(\mathrm{cmol} / \mathrm{kg})$. 


\subsection{Plutonium}

\subsection{Plutonium Toxicity}

The toxicity of plutonium is related to the radioactive properties of the radionuclide rather than its chemical properties. Its chemical properties affect the distribution, biological half-life, and the retention of plutonium in target organs. Plutonium emits alpha particles that are highly ionizing and, therefore, damaging. However, tissue penetration is slight, and biological damage is limited to cells in the vicinity of the alpha-emitting substance. Plutonium isotopes generally exist as complexes with other elements and compounds. These complexes vary in their solubility in living tissues and, thus, vary also in their uptake, transport, and retention in an organism.

\subsubsection{Plutonium Toxicity in Aquatic Biota}

A plutonium activity concentration of $7.5 \mu \mathrm{Ci} / \mathrm{mL}(0.4 \mathrm{ppm})$ reduced hatching success of carp eggs (Cyprinus carpio). All larvae that hatched were abnormal and died within a few hr (Till 1978). The lowest concentration that produced a significant effect in the carp eggs was $1.6 \mu \mathrm{Ci} / \mathrm{mL}$. Fathead minnows were more sensitive to plutonium. A concentration of $1.0 \mu \mathrm{Ci} / \mathrm{mL}$ decreased the hatching of minnow eggs. The lowest concentration that increased the frequency of abnormal larvae was $0.076 \mu \mathrm{Ci} / \mathrm{mL}$ (Till and Baylock 1976). A concentration of $1.0 \mu \mathrm{Ci} / \mathrm{mL}(0.06 \mathrm{ppm})$ affected the hatching of fathead minnow eggs.

Information on the effects of ionizing radiation is summarized in Section 2.1.

\subsubsection{Plutonium Toxicity in Terrestrial Biota}

The toxicity of plutonium in terrestrial biota is described below.

\section{Plants}

Information on the effects of ionizing radiation is summarized in Section 2.1.

\section{Invertebrates}

In long-term field experiments with plutonium-239/241 in chernozem soils $\left(1780 \mathrm{Ci} / \mathrm{m}^{2}\right.$, plowed to a depth of 25 to $30 \mathrm{~cm}$ and sown in wheat), the radionuclide was shown to decrease the population density of earthworms and insect larvae by $50 \%$ over a period of 3 years. Microarthropod populations were decreased by a factor of 7.5. Plutonium was particularly radiotoxic to those micorarthropod species that have a fast rate of development such as gamasid and throglyphoid mites. The density of small acariform mites decreased by a factor of 18 in plutonium-contaminated plots. After 
18 years, macrofaunal populations were comparable to those in control plots when the major portion of plutonium-241 had been transformed to americium-241 (Krivolutsky et al. 1992).

Information on the effects of ionizing radiation is summarized in Section 2.1.

\section{Mammals}

High-radiation doses of plutonium have resulted in decreases in life span, injury of the respiratory tract, and cancer. Target tissues are the lungs and associated lymph nodes, bone, and liver.

Toxic Response from Oral Exposure. Little information is available on the toxic response of mammals to oral ingestion of plutonium compounds, probably because of the very limited absorption of plutonium from the gastrointestinal tract. (See Section 4.2.4., Fiutonium Toxicokinetics: Metabolism and Distribution.)

The NOAEL related to mortality from acute oral exposure to plutonium (as plutonium-238 citrate) is $1 \times 10^{5} \mathrm{pCi}$ plutonium-238/kg body weight in neonatal rats. Exposure to $3.3 \times 10^{8} \mathrm{pCi} / \mathrm{kg}$ resulted in $45 \%$ mortality and growth inhibition in the survivors (Fritsch et al. 1987).

Histological changes were observed in the large intestine of adult rats given $160 \mathrm{mCi}$ plutonium239 dioxide/kg body weight. However, the changes were resolved by 6 days post-exposure (Sullivan et al. 1960). Histological changes in the gastrointestinal tract (e.g., hypertrophy of the crypts of the small intestine) of neonatal rats were produced when the rats were exposed to $1.0 \times 10^{5} \mathrm{pCi}$ plutonium-239 dioxide/kg body weight. Exposure to $3.3 \mathrm{mCi} / \mathrm{kg}$ resulted in intestinal hemorrhaging and disappearance of the crypts (Fritsch et al. 1987). However, as Fritsch et al. (1987) points out, immature development of the crypts of the small intestine is characteristic of neonatal rats, suggesting that young rats may be more sensitive to the radiological effects of plutonium than adult rats or other neonatal mammals.

Toxic Response from Inhalation Exposure. Significant decreases in longevity have been reported in rats, mice, hamsters, and dogs exposed to aerosols of plutonium-239 or plutonium-238. Early death (within 1 to 3 years after exposure) was usually caused by radiation pneumonitis and related respiratory damage. Single exposures resulting in lung depositions of $2.3 \times 10^{4}$ to $7.2 \times 10^{6} \mathrm{pCi} / \mathrm{kg}$ body weight decreased survival time in these species in a dose-related manner (Metivier et al. 1986; Sanders 1977, 1978; Sanders et al. 1986; Lundgren et al. 1987; Dagle et al. 1988; Park et al. 1988). Dogs receiving about $1.0 \times 106 \mathrm{pCi}$ plutonium/kg body weight died within 600 days of exposure, whereas dogs receiving $2.1 \times 10^{5} \mathrm{pCi} / \mathrm{kg}$ survived 1000 to 2000 days (Mewhinney et al. 1987). Longer exposures (i.e., once every other month for a total of 6 doses over 10 months) at somewhat lower doses (deposited levels of $1.8 \times 10^{4} \mathrm{pCi} / \mathrm{kg}$ ) also resulted in decreased survival time in mice (Lundgren et al. 1987). However, hamsters receiving similar exposures had 
survival times similar to controls (Lundgren et al. 1987). Chronic exposure to plutonium at levels below those causing radiation pneumonitis can result in fibrosis and associated pulmonary dysfunction (Muggenburg et al. 1986).

The earliest observed biological effect in mammals chronically exposed to plutonium was lymphopenia. Lymphopenia occurred in dogs at deposited levels of about $6.1 \times 10^{3} \mathrm{pCi} / \mathrm{kg}$ for plutonium dioxide (Park et al. 1988) and at $1.3 \times 10^{5} \mathrm{pCi} / \mathrm{kg}$ for plutonium-239 nitrate (Ragan et al. 1986; Dagle et al. 1988). Deposited lung tissue levels of $2.4 \times 10^{4} \mathrm{pCi} / \mathrm{kg}$ body weight and higher in dogs (Park et al. 1988) and $3.5 \times 10^{5} \mathrm{pCi}$ in hamsters (Lundgren et al. 1983) resulted in degenerative liver lesions. Levels as high as $7.1 \times 104$ did not cause liver lesions in hamsters (Lundgren et al. 1983).

Toxic Response from Dermal Exposure. No studies are available on the effects of plutonium on the health of wild or domestic mammals following dermal exposure to plutonium.

Immunological Effects of Plutonium Exposure. Inhaled plutonium is transported to and concentrated in lymph nodes, reaching higher concentration in the lymph nodes than in the lungs (Bair et al. 1989). Lymphadenophathy in dogs was associated with plutonium levels in lung tissue as low as $1.7 \times 10^{3} \mathrm{pCi} / \mathrm{kg}$ body weight of plutonium-239 dioxide (Park et al. 1988). Other immune system effects in mammals included development of fibrosis of the tracheobronchial lymph nodes in dogs (Gillett et al. 1988), decreased numbers of antibody-forming cells in hamsters (Bice et al. 1979), reduced numbers of pulmonary alveolar macrophages in mice (Moores et al. 1986), and depressed primary antibody responses in dogs (Morris and Winn 1978). The LOAEL for depressed antibody production was $7.1 \times 10^{4} \mathrm{pCi} / \mathrm{kg}$ body weight (Bice et al. 1979), and the lowest plutonium level causing decreased macrophage production was $4.5 \times 10^{4} \mathrm{pCi} / \mathrm{kg}$ (Moores et al. 1986).

Reproductive Effects of Plutonium Exposure. No studies were found on the reproductive effects of inhaled or ingested plutonium. Plutonium exposure of male mice via intravenous injection (1.6 $\times 10^{6}$ to $1.6 \times 10^{7} \mathrm{pCi} / \mathrm{kg}$ ) resulted in fetal intrauterine deaths in female mice mated with male mice treated 4 weeks prior to mating (Lüning et al. 1976a, 1976b). Exposure to higher concentrations resulted in male sterility at 12 weeks post-exposure (Lüning et al. 1976a, 1976b). The dominant lethal mutations caused by the plutonium were also expressed in the $\mathrm{F} 1$ males and affected the F2 generation (Lüning et al. 1976a, 1976b).

Carcinogenic Effects of Plutonium Exposure. Depending on the route of exposure, chemical form, and mammalian species, plutonium is a lung, skeletal, and liver carcinogen. Lung tumors were the most frequently observed cancer in dogs exposed to plutonium-239. The LOAEL related to lung tumor development in dogs for plutonium-239 was as low as $6.2 \times 10^{3}$ (Park et al. 1988) to $2.1 \times$ $10^{4} \mathrm{pCi} / \mathrm{kg}$ body weight (Muggenburg et al. 1987). Intermittent exposure to plutonium-239 dioxide with lung deposition levels totaling $8.6 \times 10^{4} \mathrm{pCi}$ plutonium-239/kg body weight resulted in a high incidence of lung tumors in rats (Sanders and Mahaffey 1981). 
Tumors have also been reported in the bone and liver, which are organs that accumulate transported soluble plutonium (e.g., plutonium-238 and the more soluble plutonium-239 forms such as nitrate) from the lung. The primary cause of cancer deaths in dogs exposed to aerosols of plutonium-238 was osteosarcomas. The lowest level producing bone cancer was $1.4 \times 10^{3}$ (Park et al. 1988) to $2.3 \times 104$ (Dagle et al. 1988).

Dogs receiving a single inhalation dose of $1400 \mathrm{pCi} / \mathrm{kg}$ plutonium via inhalation developed bone cancer after 4 years. Mice exposed to plutonium-239 once every other month for a total of six doses over 10 months developed bronchial hyperplasia at deposition levels of $8.1 \times 10^{4}$ and above (Lundgren et al. 1987).

Note that Syrian hamsters appear to be resistant to lung tumor induction by acute, intermittent, or chronic exposure to plutonium or other alpha-emitting radionuclides (Sanders 1977; Lundgren et al. 1983; ATSDR 1990b).

Genotoxicity. In hamsters, inhaled plutonium at deposited levels of $1 \times 10^{7}$ to $2.6 \times 10^{8} \mathrm{pCi} / \mathrm{g}$ lung tissue resulted in a dose-related increase in the frequency of chromosomal aberrations in blood cells 30 days after exposure (Brooks et al. 1976).

Biomarkers of Plutonium Exposure/Effect. Alpha activity of the urine is a well-established biomarker of exposure to plutonium. Models have been developed to estimate body burden of radiation workers from radioactivity in the urine. It should be noted, however, that body burdens of plutonium determined from tissue analysis at autopsy have been lower than those generated from urinalysis data (Voelz et al. 1979). No data are available on the relationship between exposure and the levels of radioactivity in the urine.

No plutonium-specific biomarkers of effect have been reported. Lymphopenia is the earliest observed biological effect in dogs and can be defined by a dose-response relationship related to inhaled plutonium (Park et al. 1988; Ragan et al. 1986). The degree to which this is a universal marker in mammals is unknown. Chromosome aberrations are also produced by plutonium exposure, but a large number of other chemicals also cause this effect, limiting the usefulness of this effect as a biomarker.

Plutonium Toxicokinetics: Absorption and Distribution. Absorption of plutonium from the gastrointestinal tract is minimal. Plutonium citrate and nitrate are absorbed more readily than other plutonium compounds. In adult rats and hamsters, absorption of these compounds ranges between $0.003 \%$ and $0.01 \%$ (Carrit et al. 1947; David and Harrison 1984; Stather et al. 1981). Absorption is age-related, and the ability of hamsters to absorb plutonium diminished from $3.5 \%$ to $0.003 \%$ from 1 to 30 days of age (David and Harrison 1984). Neonatal rats, hamsters, guinea pigs, and dogs absorbed $3 \%$ to $6 \%$ of administered plutonium (Cristy and Leggett 1986). 
Absorption of inhaled plutonium is dependent on the mass deposited, the chemical compound and the particle size (Bair et al. 1962; Guilmette et al. 1984). Less soluble plutonium compounds, such as plutonium-239 dioxide, will be retained longer in lung tissue following inhalation than the more soluble forms, such as plutonium-239 nitrate and the plutonium-238 compounds. Particle size determines the deposition pattern in the lung and the clearance of the radionuclide from the lung. Thus, retention and radiological dose are directly related to particle size as is distribution to target organs. In mammals, particle sizes less than or equal to $10 \mu \mathrm{g}$ Activity Median Aerodynamic Diameter (AMAD) are able to penetrate to the deep lung and be available for absorption (NEA 1981).

Dermal uptake of plutonium on intact palmar skin of a human is less than or equal to $0.0002 \% / \mathrm{h}$ in acid solution (Langham 1959). Hair follicles (Weeks and Oakley 1955) and sweat and sebaceous glands (Buldakov et al. 1972) have been found to be portals for plutonium uptake through the skin.

Soluble forms of plutonium are accumulated largely in bone and liver (Dagle et al. 1985; Morin et al. 1972), whereas the less soluble forms are distributed to the lymph nodes and liver (Bair et al. 1966; Park et al. 1972). An hepatic uptake of $45 \%$ has been adopted by ICRP (1975a, 1975b, 1979. 1986) for setting annual limits of intake for plutonium. However, partioning between the liver and skeleton varies widely among individuals (ICRP 1986), and hepatic uptake of 55\% and $68 \%$ have been reported (Talbot et al. 1992).

In tests on dogs, ingested plutonium was excreted in the feces. About $98 \%$ of the dose was excreted after 5 to 6 weeks (Toohey et al. 1984). Total retention of plutonium in mice and rats ranged from $0.17 \%$ to $0.24 \%$ (Larsen et al. 1981). Loss of deposited plutonium from the liver was rapid (Taylor et al. 1981, 1983), and liver retention in laboratory mice and rats was $0.036 \%$ and 0.54\%, respectively (Larsen et al. 1981). However, deer mice (Peromyscous maniculatus) and grasshopper mice (Onychomys leucogaster) retained plutonium in the liver for prolonged periods (Taylor et al. 1981, 1993). Neonates retained 100 times more plutonium from oral uptake than did adults (Sullivan et al. 1984). Inhaled plutonium was excreted in two phases. In the first phase (20 to 30 days in rats), about $70 \%$ to $76 \%$ of the plutonium was removed. The remainder was removed during the second phase (180 to 250 days) (Sanders et al. 1986, 1977). However, translocated plutonium may be retained in the body for many years. About $85 \%$ of the plutonium-239 dioxide dose inhaled by dogs was retained up to 10 years post-exposure (Park et al. 1972).

\section{Birds}

No information is available on plutonium effects in wild birds. Ionizing radiation effects are summarized in Section 2.1.1. 


\subsection{Bioconcentration Factors and Trophic Transfer Coefficients}

Solubility of plutonium depends on the chemical form in which it enters the soil or sediment environment, the properties of the soil/sediment, the presence of complexing agents, and the soil/ sediment microbe content (Bell and Bates 1988; Kabata-Pendias and Pendias 1984; WHO 1983; Wildung and Garland 1980). Once plutonium enters the soluble phase, it becomes available for uptake by plants. Availability of plutonium in water is dependent upon the oxidation state and the nature of the sediment and suspended solids.

\subsubsection{Plutonium Transfer in Aquatic Food Chains}

Freshwater studies indicate that plutonium is concentrated in algae but decreases by about a factor of 10 at each trophic level in the food chain (Noshkin et al. 1973; Hanson 1975). Concentration ratios for algae range between about $2.8 \times 10^{2}$ to $5 \times 10^{6}$ on a wet weight basis (Noshkin et al. 1973; Hanson 1975). Transfer of plutonium from water to seston was very high $\left(1.7 \times 10^{4}\right.$ to $\left.1 \times 106\right)$ in freshwater systems at the Rocky Flats plutonium fabrication plant, Golden, Colorado. The bioconcentration of plutonium in the zooplankton of the ponds was about $1.6 \times 10^{3}$ relative to plutonium content of the water. The plutonium transfer coefficient from phyoplankton to zooplankton was about 0.1 . A concentration factor of 320 to 1290 was found in crayfish in the contaminated ponds. Over $75 \%$ of the plutonium in the crayfish was associated with the exoskeleton. Fish (minnows, carp, and bass) accumulated very little of the plutonium. Concentration factors relative to water ranged from 0 to 34 for whole fish. Plutonium was not detected in any fish flesh samples (Paine 1980). Plutonium concentration ratios of $5 \times 10^{6}$ (water-based) have been reported for aquatic snails. Aquatic beetles (Coleoptera sp.) concentrate plutonium by a factor of $3 \times 10^{5}$ (water) (Eyman and Trabalka 1980). Fish eggs have been shown to concentrate plutonium by a factor of 4 over the concentration of the water (Till 1978). In the absence of site-specific data, recommended default values for the water-based bioconcentration factor for plutonium in the flesh of freshwater fish are 350 (NRCC 1982), 50 for fish in water of low mineral content and 10 for fish in water of high mineral content (CSA 1987), 250 (Myers 1989), and 5 for piscivores fish, 25 for planktivores, and 250 for bottom-feeding fish 5 (Poston and Klopfer 1985).

Bottom sediments are a major reservoir for plutonium in the aquatic environment. Trablaka and Eyman (1976) determined the sediment-based transfer factors for plutonium-237 in the biota of an aquatic microcosm. Plant uptake of plutonium was much greater in submerged vegetation and algae ( 0.2 to 27.0$)$ than in emergent plants $(0.03$ to 0.11$)$ and may, in part, be due to adsorption of the radionuclide to the submerged plant tissue. Transfer coefficients in whole animals ranged from 1.2 to 9.9. Trophic transfer coefficients for the biota in the microcosm are listed in Table 4.1. Another microcosm study (Trabalka and Frank 1978) produced similar trophic transfer coefficients, but added a factor for the larvae of the dipteran family, specifically Chironomus riparus. Dipteran larvae are important components of the diet of freshwater fish. They inhabit and feed on bottom sediments where plutonium cuntamination is greatest. The reported transfer factor for the dipteran larvae in the microcosm was 0.4 to 0.79 . However, this value was for larvae from which the gut contents had been 
Table 4.1. Sediment-Based Trophic Transfer Coefficients for Plutonium-237 in Biota of an Aquatic Microcosm (Trabalka and Eyman 1976)

\begin{tabular}{l} 
Organism \\
\hline Emergent Plants \\
Grass (Panicum) \\
Cattail (Typha) \\
Watercress (Nasturtium) \\
Submerged Plants
\end{tabular}

Algae (Oedogonium)
Moss (Hygrohypnum)
Stonewort (Chara)
Pondweed (Potamogeton)
Invertebrates

Snails (Physa)

(Gyraulus)

(Goniobasis)

Amphipod (Hyalella)

Vertebrates

Goldfish (Carassius)
Sample Type Trophic Transfer Coefficient

$\begin{array}{ll}\text { Leaves and shoots } & \leq 0.045 \\ \text { Leaves and shoots } & \leq 0.035 \\ \text { Leaves and shoots } & \leq 0.089\end{array}$

$\begin{array}{lc}\text { Clumps } & 9.1 \\ \text { Branches } & 27.0 \\ \text { Branches } & 0.19 \\ \text { Leaves and shoots } & 2.5\end{array}$

Whole body

1.5-2.4

Carcass

1.2

Whole body

6.4

Whole body

5.0-9.9

Carcass

3.5

3.6

Whole body

2.3

Whole body

Flesh
0.47

removed. A more realistic transfer coefficient also would incorporate the gut content exposure (Trablaka and Frank 1978). With the gut contents included, the trophic transfer coefficient for dipteran larvae is 7.1 .

Aquatic birds do not appear to bioconcentrate plutonium above levels found in their diet. Plutonium accumulation ( $3.2 \mathrm{pCi} / \mathrm{kg}$ ) in the viscera of the thick-billed murre and black guillemot (Ceppus grylle) was similar to that of the zooplankton in birds' diet (Lowman et al. 1970). Eider 
duck (Somatiera sp.) feeding in an area where plutonium had been released from nuclear weapons in an aircraft accident near Greenland had tissue concentrations equal to background levels (Aarkrog 1971).

Concentration ratios for plutonium in aquatic macrophytes are $10^{-2}$ to $10^{-1}$ relative to sediment plutonium concentrations (Emery et al. 1974; Emery and Farland 1974; Emery et al. 1975a, 1975b; Emery et al. 1980; Paine 1980).

\section{Plutonium Transfer through Terrestrial Food Chains}

Most (96\% to 98\%) of the plutonium entering soils is initially immobilized (Garland and Wildung 1977) and only a small portion is soluble in soil solution (Jacobson and Overstreet 1948; Price 1972). Because of the small fraction of soluble plutonium in soils, accumulation of plutonium in soil-dwelling organisms is low. The bioconcentration factor for earthworms living in soils containing 3.5 MBq plutonium-239/Kg was 0.0034 (Krivolutsky et al. 1992).

In addition to hydrolysis of plutonium in soil to insoluble forms that are unavailable to the plant, discrimination by plants against plutonium at the root membrane level also occurs (Garland et al. 1987). Soil-to-plant concentration ratios ranging from $1 \times 10^{-6}$ to $2.5 \times 10^{-4}$ plutonium in wet vegetation/plutonium in dry soil are typically measured in laboratory studies and crop plants. The findings indicate that plutonium is relatively unavailable for incorporation into plants (Jacobson and Overstreet 1948; Price 1972; Romney and Davis 1972; Wilson and Cline 1966). However, soil microbes have been found that are resistant to plutonium and increase the solubility of the radionuclides in soil. The uptake of plutonium on successive cropping of plutonium-contaminated soil increased to $0.01 \%$ of the plutonium present in the soil (Robinson et al. 1977). It should be noted that concentration factors for native plants range from 0.02 to 0.7 . These values are 0.1 to 10,000 times greater than the concentration factors observed in laboratory studies (Hakonson et al. 1973; Hakonson and Johnson 1973; Larson et al. 1951; Leitch 1951; Olafson et al. 1957; Whitner et al. 1973). A general concentration factor of $2 \times 10^{-3}$ has been commonly used for plutonium uptake in plants (Garten et al. 1987). A concentration factor of $10^{-4}$ was reported for plutonium in plants from the Nevada Test Site (Olafson and Larson 1963).

Once plutonium is absorbed by plants, natural ligands or metabolites effectively stabilize the plutonium. Thus, plutonium is not very mobile in plants as evidenced by low stem, leaf, and seed concentrations (Cataldo et al. 1987). Indeed, the roots contain the highest concentration of plutonium in the plant. The plutonium may be present in the root as a stabilized complex, a soluble complex, or a surface-adsorbed complex (Garland et al. 1981). About $1 \%$ to $3 \%$ of the plutonium in an ecosystem is associated with the root.

Because little plutonium is associated with edible vegetation, organisms feeding on the aboveground portions of the plants accumulate very little of the radionuclide. Therefore, plutonium is not concentrated along terrestrial food webs. Inhalation of plutonium particles and ingestion from 
grooming may be important sources of plutonium contamination in fossorial animals (Hanson 1975). Garten et al. (1987) reported a concentration ratio of $4 \times 10^{-5}$ in terrestrial mammals. Concentration factors for plutonium in desert mammals of the Nevada Test Site are listed in Table 4.2.

Table 4.2. Concentration Ratios for Plutonium in Desert Mammals (Romney et al.. 1970, 1979)

Trophic Level

Granivore

Omnivore

Insectivore
Carcass/Soil

$0.0067-0.17$

$0.0067-0.053$

0.02-0.080
Carcass/Vegetation

$0.02-0.51$

$0.020-0.157$

0.0588-0.235 


\subsection{Cesium}

\subsection{Cesium Toxicity}

Cesium is a chemical analog of potassium and exhibits relatively low toxicity in most organisms. However, caustic compounds of cesium can be highly toxic. As a photon emitter, cesium's radiation toxicity can be substantial. See Section 2.1 for a review of radiation toxicity in aquatic and terrestrial organisms.

\subsubsection{Toxicity of Cesium in Aquatic Biota}

\section{Aquatic Plants}

See Section 2.1 for effects of ionizing radiation on biota.

\section{Invertebrates}

Little information is available on cesium toxicity to aquatic invertebrates. However, the presence of cesium-137 in an industrial pond (sediment concentrations of about $28,000 \mathrm{pCi} / \mathrm{g}$ dry weight $0.29 \mathrm{ng} / \mathrm{g}$ ) did not prevent the colonization of the pond by numerous invertebrate species including annelids, cladocerans, copepods, amphipods, and several species of aquatic insects and gastropods (Rickard et al. 1981). The toxicity of cesium varied greatly among the invertebrates. For example, the 48-h LC50 for the copepods, Cyclops absysorium and Eudiaptomus padanus, was $400 \mathrm{mg} / \mathrm{L}$ and $135 \mathrm{mg} / \mathrm{L}$, respectively. Daphnia hyalina was much more sensitive to cesium with a 48-h LC50 of $7.4 \mathrm{mg} / \mathrm{L}$ (Baudouin and Scoppa 1974).

See Section 2.1 for effects of ionizing radiation on biota.

\section{Fish}

Allergic effects of cesium-137 have recently been reported in fish exposed to $2000 \mathrm{~Bq} / \mathrm{L}$ or more. Hyperemia and focal fatty degeneration of hepatic cells were observed in poisoned fish. Damage was also seen in brain and epithelial cells of renal tubules (Vosniakos et al. 1991). A selfsustaining, apparently healthy population of carp has been monitored for 2 decades in an industrial pond containing sediment levels of cesium-137 of about 28,000 pCi/g dry weight (Rickard et al. 1981). Fish embryos are also tolerant of cesium exposure. Exposure to up to $10 \mu \mathrm{Ci} / \mathrm{L}$ of cesium-137 for 20 days did not increase the mortality rate of rainbow trout embryos (Kimura and Honda 1977a, 1977b). 


\subsubsection{Toxicity in Terrestrial Biota}

Information regarding cesium toxicity in terrestrial biota is summarized below.

\section{Plants}

Bulrushes (Sciprus acutua), cattails (Typha latifolia), and pondweeds (Potamogeon sp. and Elodea) were not inhibited from colonizing an industrial pond containing cesium concentrations in the sediment of $28,000 \mathrm{pCi} / \mathrm{g}$ dry weight (Rickard et al. 1981).

See Section 2.1 for effects of ionizing radiation on biota.

\section{Invertebrates}

See Section 2.1 for effects of ionizing radiation on biota.

\section{Amphibians/Reptiles}

No information available.

\section{Mammals}

Cesium can replace potassium to some extent in mammals (Relman 1957) and, therefore, cesium is distributed by the blood stream throughout all the active tissues resulting in, essentially, a dose to the whole body (Boecker 1972). Acute toxicity and death are related primarily to bone marrow destruction. Shortening of life has also been observed in mammals exposed to cesium and appears to be related to delayed development of neoplasia (Norris et al. 1966). These effects are the same as those associated with gamma or $x$-irradiation and are summarized in Section 2.1 (Toxic Effects of Ionizing Radiation).

The toxic response of mammals to cesium resembles rubidium and potassium toxicity. Liver injury, neuroendocrine and neuromuscular disturbance leading to irritability and convulsions are clinical signs of cesium toxicity (Venugopal and Luckey 1978). The oral LD50 of cesium (without regard to its radioactive toxicity) is $84.6 \mathrm{mg} / \mathrm{kg}$ body weight as cesium hydroxide. The parenteral LD50s of cesium nitrate, cesium carbonate, and cesium halide compounds range from 716 to $1330 \mathrm{mg} / \mathrm{kg}$ (Venugopal and Luckey 1978). The greater toxicity of cesium hydroxide is probably due to its caustic action (Cochran et al. 1950). The lowest oral LD50 of non-caustic forms of cesium was $710 \mathrm{mg} / \mathrm{kg}$ in mice (Lewis and Tatken 1979-1980). Irradiation of female cotton rats in enclosed areas of a natural habitat showed that LD50/15 for cesium-137 was $1130 \mathrm{R}$ and that survival time and dose were directly related. At $500 \mathrm{R}$, a $91 \%$ survival rate was observed, whereas only $25 \%$ survived $1200 \mathrm{R}$ (Pelton and Provost 1969). 
Recent epidemiological studies have indicated that exposure of a human fetus at 8 to 15 weeks conceptus results in mental retardation at a rate of $30 \mathrm{IQ}$ points/Sv (Harley 1991). No behavioral studies are available to assess if any comparable behavioral deficits occur in other mammals exposed to cesium.

Immunological Effects of Cesium Exposure. Immune system dysfunction has been recently described in fish (Section 5.1.1 Eish).

Reproductive, Carcinogenic, and Genotoxic Effects of Cesium Exposure. See Section 2.1 on effects of ionizing radiation.

Biomarkers of Cesium Exposure/Effect. Whole body levels of cesium in humans have been estimated from blood concentrations (Salo et al. 1963). Chronic exposures to cesium in mice and dogs have shown that the major accumulator organ is muscle. Other organs (fat, blood, skin, and bone) accumulate cesium, but at much lower concentrations. In fish, accumulator organs include muscle, gills, liver, and kidneys (Vosniakos et al. 1991). However, no direct relationship between tissue levels and effects has been reported. In mule deer, about $80 \%$ to $90 \%$ of total body cesium is concentrated in muscle tissue (Hakonson 1975).

Cesium Toxicokinetics: Metabolism and Distribution. Cesium uptake from the gastrointestinal tract is rapid and nearly complete (70\% to 100\%) (Reichle et al. 1970a, 1970b). Generally, absorption of cesium from the digestive tract of monogastric animals is greater than or equal to $90 \%$ and about $80 \%$ in ruminants (Stara et al. 1971). In rats, about $98 \%$ of ingested cesium is absorbed within 30 minutes. Excretion of cesium is rapid and mainly urinary, although $25 \%$ of the absorbed dose can be excreted in the feces (Salo et al. 1963). Distribution of the radionuclide in the body is broad, but mostly to the soft tissues. Like other alkali metals, cesium occurs mainly as a free ion in tissues and fluids. Little binding occurs of cesium to biologically active macromolecules (Venugopal and Luckey 1978). Humans do not accumulate cesium with age, which suggests a poorly defined homeostasis for cesium (Venugopal and Luckey 1978).

The biological half-life of cesium for many wild mammal species has been assumed to be 33 days, a value determined for reindeer by Ekman (1967). However, the biological half-life of radiocesium in pocket mice has been determined to be 5.3 days (Winsor and O'Farrell 1970). The half-life of cesium-137 in mule deer is about 14 days. The biological half-life of cesium-137 in small mammals is listed in Table 5.1. 
Table 5.1. Biological Half-Lives of Cesium-137 in Small Mammals Native to the Hanford Site (Rickard et al. 1974; Winsor and O'Farrell 1970)

\section{Species}

Sagebrush Vole (Lagurus curtatus)

Montane Meadow Mouse (Microtus montanus)

Great Basin Pocket Mouse (Perognathus parvus)

Westem Harvest Mouse (Reithrodontomys megalotis)

Northern Grasshopper Mouse (Onychomys leucogaster)

Deer Mouse (Peromyscus maniculatus)

House Mouse (Mus musculus)
Half-Life (days)

4.4

4.5

5.3

5.4

5.6

6.3

9.4

Biological half-lives for mammals not listed in Table 5.1 may be estimated by the equation:

$$
\text { Half-life (days) }=3.458(\text { body weight) } 0.2061
$$

as reported by Reichle et al. (1970a, 1970b).

\section{Birds}

Levels in birds exposed to high levels of radiocesium in the environment have been reported to be in excess of the maximum permissible concentrations for man. However, it was not determined if these levels (average body burden of $5 \mu \mathrm{Ci}$ ) were harmful to the birds (Krumholz 1954). Red blood cell abnormalities in mallards that accumulated cesium-137 from an abandoned nuclear reactor cooling tower were observed after 8 months of exposure. Aneuploidy in the blood cells was observed after 9 months of exposure. Such changes only occurred with maximum body burdens of cesium-137 (George et al. 1991). Willard (1963) calculated that a chronic dose LD50 of $21,700 \mathrm{mGy}$ would be needed to kill $50 \%$ of bluebird (Sialia sialis) nestlings over a 16-day period of irradiation with cesium-137. Growth of tree swallows was significantly affected by acute doses of 2700 to $4500 \mathrm{mGy}$ (Zach and Mayoh 1984). Hatching success was reduced by chronic doses of $100 \mathrm{mGy} / \mathrm{d}$ (Zach and Mayoh 1984). Birds environmentally exposed to cesium-137 during breeding season received total dose equivalent rates to the whole body of $9.8 \times 10-7 \mathrm{~Sv} / \mathrm{h}$ or $2.8 \mathrm{mSv}$ for the whole period of 120 days (breeding season). No reproductive or population effects were observed in even the most contaminated individuals and species (Lowe 1991). The number of eggs and chicks produced by American coot (Fulica americana) colonizing a cooling pond that received low levels of cesium-137 were similar to the number produced on uncontaminated ponds (Rickard et al. 1981). The coots consumed aquatic plants containing about $11,000 \mathrm{pCi}$ of cesium/g dry weight and, inadvertently, sediments containing about $28,000 \mathrm{pCi}$ of cesium/g dry weight (Rickard et al. 1981). 


\subsection{Bioconcentration Factors and Trophic Transfer Coefficients}

Soil properties greatly influence cesium availability and ecosystem cycling. High clay content effectively immobilizes cesium by chemical binding, thus removing cesium from food chains. However, biological incorporation is substantial in systems containing sandy soils and sediments and low cation exchange capacity (Whicker and Shultz 1982). Biotic accumulation also appears to be dependent on potassium abundance in the environment. In general, cesium concentration factors decrease with each trophic level. However, biomagnification occurs in specific food chains.

\subsubsection{Cesium Transfer in Aquatic Food Chains}

Physical absorption is a major mode of uptake of cesium for algae and zooplankton (Cushing and Watson 1966). Assimilation of ingested cesium varies with the type of food consumed. For example, carp assimilate $80 \%$ of the cesium on algae but only $7 \%$ of the cesium in the organic detritus of the sediment (Kevem 1966). Assimilation from water is about 73\%. The general aquatic concentration factors for cesium are listed in Table 5.2. Duckweed (Spirodela punctata)

Table 5.2. Water-Based Concentration Factors for Cesium in the Aquatic Food-Chain (Reichle et al. 1970a, 1970b; Dunford et al. 1985; Voshell et al. 1985; Cushing and Watson 1974; and Rickard et al. 1981)

Trophic Level

Water

Algae

Higher Plants

Invertebrates

Frog Muscle

Fish

Waterfowl Flesh

$\begin{array}{ll} & \text { Higher Plants } \\ \text { Invertebrates } \\ \\ \text { Frog Muscle } \\ \text { Fish } \\ \text { Waterfowl Flesh } \\ \end{array}$

Consumer Type

ronsumer Type

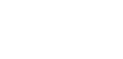

\section{Concentration Factor}

1.0

$500-4,000$

$50-25,000$

Saprovore (detritus-feeder)

60-11,000

600

800

Carmivore

8,000

$125-6,000$

$640-9,500$

Carnivore

2,000 
concentrates cesium by a factor of 1000 to 5500 (Polar and Bayulgen 1991). Lower concentration factors (90 to 180) are reported for duckweed in waters containing high concentrations of potassium (Bergamini et al. 1979).

Body size appears to influence cesium-137 uptake in fish (Spigarelli and Edwards 1975). About $34 \%$ of the cesium in chironomid larvae is assimilated by bluegills weighing 0.5 to $1.2 \mathrm{~g}$. Fish weighing 9 to $10 \mathrm{~g}$ assimilated $71 \%$ of the cesium, and 80 - to $120 \mathrm{~g}$ bluegills absorbed $92 \%$ of the ingested cesium (Reichle et al. 1970a, 1970b). Koulikov and Ryabov (1992) described a first-order kinetic model of cesium-137 uptake and excretion in fish that interprets the weight dependence of cesium concentrations in fish flesh and liver.

Additional references on bioaccumulation of cesium in freshwater fish suggest a wider range of concentration factors from 19 to 22,000. Water-based bioconcentration factors for fish species that are locally relevant or are used extensively in aquatic toxicity studies are listed in Table 5.3. The wide range is related to differences in growth, feeding habits, and temperature and water quality parameters (Srivastava et al. 1990). A parameter that greatly affects accumulation of cesium in fish is the potassium concentration in the water. For example, the concentration factor in fish from water with a potassium concentration of $0.074 \mathrm{mmol} / \mathrm{L}$ was $15.7 \pm 3.4$, whereas the concentration factor from water with potassium levels of $10 \mathrm{mmol} / \mathrm{L}$ was $2 \pm 0.4$ (Srivastava et al. 1990). In zebra fish, the concentration factor for cesium in whole fish is inversely dependent on the potassium content of the water: $\mathrm{CF}=5.2[\mathrm{~K}+]-0.44$. In the absence of site-specific data, recommended default values for the water-based bioconcentration factor for cesium in the flesh of freshwater fish are 400 (NRCC 1982), with $10^{4}$ for fish in water of low mineral content and 100 for fish in water of high mineral content (CSA 1987). Myers et al. (1989) also recommended a default bioconcentration factor of $10^{4}$. Default values of 0.5 and 15,000 were recommended by Poston and Klopfer (1985) for nonpiscivorous and piscivorous fish, respectively, in water containing $1 \mathrm{mg} / \mathrm{L}$ potassium . At $100 \mathrm{mg} / \mathrm{L}$ potassium, the recommended values were 0.5 and 500 for nonpiscivores and piscivores, respectively (Poston and Klopfer 1985). For zebra fish, the elimination rate for cesium in freshwater is $0.014 \pm$ $0.003 / \mathrm{d}$, and the biological half-life is $51 \pm 10$ days (Srivastava et al. 1990). A bioconcentration factor of 0.4 has been reported for cesium in rainbow trout eggs (Kimura and Honda 1976b).

Results from a study in which cesium-134 and 5 other radiotracers were added to the epilimnion of a whole lake indicate that direct accumulation of cesium from water is not a major route of uptake in fish. Despite an epilimnetic half-life of 28.1 days, a continuous increase in cesium-134 activity in fish gut contents over a 247-day period was observed (Klaverkamp et al. 1983). Food appeared to be the major exposure pathway. The main source of cesium for cycling in food webs among the biotic and abiotic components of aquatic systems is the sediment. Sediment-based transfer coefficients for cesium in an aquatic food chain can be estimated from studies by Rickard et al. (1981) and Cushing and Watson (1974). These values are presented in Table 5.4. 
Table 5.3. Bioconcentration Factors for Cesium in Fish Based on Cesium Levels in Water

\begin{tabular}{|c|c|c|}
\hline Species & Bioconcentration Factor & Reference \\
\hline Brown Trout (Salmo trutta) & 5 & Hewett and Jefferies 1976 \\
\hline Perch (Perca fluviatills) & $\begin{array}{c}122-1,000 \\
\text { (eutrophic) } \\
4,867-15,022 \\
\text { (oligotrophic) }\end{array}$ & $\begin{array}{l}\text { Kolehmainen et al. } 1966 \\
\text { Kolehmainen et al. } 1966\end{array}$ \\
\hline Walleye (Stizostedion vitreum vitreum) & $640-2,500$ & Dunford et al. 1985 \\
\hline Fathead Minnow (Pimephales promelas) & 3,170 & Harrison et al. 1990 \\
\hline Lake Trout (Salvelinus namaycush) & 7,040 & Harrison et al. 1990 \\
\hline \multicolumn{3}{|l|}{ Rainbow Trout (Oncorhynchus mykiss) } \\
\hline Fry (10 days old) & 0.4 & Kimura and Honda 1977a \\
\hline Fingerlings ( 5 months old) & 1.3 & Kimura and Honda $1977 \mathrm{a}$ \\
\hline Carp (Cyprinus carpio) & 12 & Horsic et al. 1982 \\
\hline Chub & 27 & Horsic et al. 1982 \\
\hline
\end{tabular}

Voshell et al. (1985) determined the uptake of cesium at the various trophic levels of an aquatic insect community. Using this information in conjunction with the reported water and sediment concentrations of cesium, the transfer coefficients at each trophic level were calculated. The algae and plankton concentrated cesium from water with bioaccumulation factors of 5200 and 11,700, respectively. Herbivorous insects (adult Coleoptera) feeding on the filamentous algae had an algaeto-insect transfer coefficient of 0.009 . The transfer coefficient of saprovores (mayflies and chronomid midges) was 0.03 . Saprovore-to-camivore (damsel flies and dragon flies) transfer was 0.93 . The transfer coefficient for predators (Notonectidae) that consumed only the body fluids of their prey was 0.16. (Note: Voshell et al. (1985) suggest that emergent insects that leave the water as adults could be used as a biomarker of cesium exposure.)

American coots (Fulica americana) utilizing a cooling pond at the Savannah River Plant accumulated 2 to $3 \mathrm{pCi}{ }^{137} \mathrm{Cs} / \mathrm{g}$ bird/m (Brisbin et al. 1973). Migratory waterfowl using the pond removed about $3.75 \times 10^{-5} \mathrm{Ci}$ of radiocesium from the pond each year and redistributed it along their migratory route (Brisbin et al. 1973). Cesium-137 was found to be the major radionuclide in birds using 
Table 5.4. Sediment-Based Bioconcentration Factors for Cesium in a Biotic Community (Rickard et al. 1981 and Cushing et al. 1974)

\begin{tabular}{|c|c|}
\hline Species & Bioconcentration Factor \\
\hline Periphyton (Chadophora sp.) & $0.88-1.83$ \\
\hline Pond weeds (Potamogeton sp.) & $0.09-0.10$ \\
\hline (Elodea) & $0.04-0.07$ \\
\hline Mollusks & 0.07 \\
\hline Insects (Coleoptera sp.) & 0.009 \\
\hline Carp & $0.01-0.011$ \\
\hline Coots (Fulica americana) & $0.01-0.03$ \\
\hline Ducks (Fish-Eating) & 0.004 \\
\hline
\end{tabular}

the Hanford 200-Area waste swamps in 1969. The range of cesium found in the muscle of the bird was 70 to $420 \mathrm{pCi} / \mathrm{g}$ (300 pCi/g average) (Wilson and Essig 1970). Concentration ratios [cesium concentration in the bird $(\mathrm{g})$ / cesium concentration in water $(\mathrm{mL})$ ] for aquatic birds have been derived experimentally (Pendleton and Hanson 1958) and range between 800 and 900 as measured in bone tissue, 1800 to 2200 for muscle tissue, and 2200 to 2800 for liver (Table 5.5).

From the above data, it is apparent that no biomagnification of cesium occurs in aquatic food webs and that cesium concentrations tend to decrease sequentially with successive tropic levels (Cushing et al. 1974; Nelson et al. 1967; Rickard et al. 1981).

\subsubsection{Cesium Transfer through Terrestrial Food Chains}

Cesium progressively decreases in concentration through invertebrate food chains, generally averaging one-half the concentration of plants after two trophic exchanges (Reichle and Crossley 1969). However, cesium concentrations increase at the higher trophic levels in mammals. A ninefold increase of cesium-137 has been reported in plant-mule deer-cougar food chains (Pendleton et al. 1964). In the lichen-caribou-wolf chain, cesium- 137 increased twofold at each successive link in the food chain (Hanson et al. 1967). The.general terrestrial food-chain concentration factors for cesium are listed in Table 5.6. Some species-specific concentration factors are listed in Table 5.7. 
- Table 5.5. Cesium Concentration Factors in Birds (Mellinger and Schultz 1975)

\begin{tabular}{llcc}
\multicolumn{1}{c}{ Species } & Tissue & $\begin{array}{c}\text { Concentration Factor } \\
\text { [bird (g)/water (mL)l }\end{array}$ \\
\cline { 1 - 1 } Coot (Fulica americana) & & 1800 \\
& & $\begin{array}{l}\text { Muscle } \\
\text { Liver }\end{array}$ & 2200 \\
& Bone & 800 \\
Mallard (Anas platyrhynchos) & & \\
& Muscle & 2000 \\
& Liver & 2500 \\
Ruddy Duck (Oxyural jamaicensis rubida) & Bone & 700 \\
& & Muscle & 2200 \\
& Liver & 2800 \\
& Bone & 900
\end{tabular}

Table 5.6. Concentration Factors for Cesium in the Terrestrial Food-Chain (Reichle et al. 1970a, 1970b)

Trophic Level

Plants

Invertebrates

Mammals

(a) Detritus-Feeder
Consumer Type

Saprovore(a)

Herbivore

Carnivore

Herbivore

Omnivore

Carnivore
Concentration Factor

1.0

0.2

0.3-0.5

$0.1-0.5$

0.3-2.0

1.2-2.0

3.8-7.0 
Table 5.7. Species-Specific Concentration Factors for Cesium in Terrestrial Ecosystems (Lowe and Horril 1991; Pendleton et al. 1964)

\begin{tabular}{lll} 
Trophic Level & Consumer & Concentration Factor \\
\cline { 2 - 3 } Herbivore & Red grouse & 1.7 \\
& Black grouse & 1.4 \\
& Blue hare & 2.0 (male), 2.5 (female) \\
& Brown hare & 3.3 \\
& Rabbit & 1.9 (males), 1.5 (females) \\
& Red deer & 1.3 (hinds), 3.8 (stags) \\
& & \\
Camivore & Cougar & 3.4 \\
& Wolf & 2.0 \\
& Fox & 11.2 (males), 7.2 (females)
\end{tabular}

As seen in Table 5.7, sex and breeding conditions influence the accumulation ratio of cesium-137 in both herbivores and carnivores. It should be noted that the concentration ratios for the carnivores are based on a single, albeit dominant, prey species instead of the variety upon which they normally feed and, therefore, they may be biased.

Cesium uptake from soil by a single crop is less than $0.1 \%$ of the soil's content (Menzel 1963). Prairie grasses concentrate cesium by factors of 0.02 to 5.0, depending on soil conditions and grass species (Schuller et al. 1993). On the basis of Menzel's classification of concentration factors of elements in plants, cesium is considered "slightly excluded" (Menzel 1963). Concentration factors for emergent seed plants range from 50 to 600 . On the other hand, Voight et al. (1991) reported root transfer factors for cesium-137 of 0.002 for grains, 0.002 for potatoes, 0.0047 for lettuce, and 0.003 for bush beans. Garland et al. (1983) found concentration factors of $3 \times 10^{-4}$ for tumble mustard and 0.5 for cottonwood and willow leaves.

Assimilation of cesium-137 from detritus is low (53\% to 65\%) because it is incorporated into poorly digested tissue structures (Reichle et al. 1970a, 1970b). Cesium in herbaceous foliage is more readily available (73\% to $94 \%$ ), especially in sap-sucking animals such as aphids (about $100 \%$ ). Flesh-eating predators also show high assimilation efficiencies for cesium (i.e., 79\% to 94\%). Transfer of cesium from forage to milk in ruminants is about $0.25 \%$ (Voors and VanWeers 1991 ). Fielitz (1991) reports a feed-to-meat transfer of 0.045 in fallow deer. 


\subsection{Strontium}

\subsection{Strontium Toxicity}

Strontium has a relatively low chemical toxicity in those aquatic and terrestrial biota that have been tested. However, because of its similarity to calcium, strontium is deposited in bone of vertebrate animals, where irradiation by beta particles can cause neoplasia and adversely affect blood cell formation.

See Section 2.1 for a review of the radiation toxicity of strontium.

\subsubsection{Toxicity of Strontium in Aquatic Biota}

See Section 2.1 for a review of the radiation toxicity of strontium.

Strontium toxicity to copepods is low. The 48-h LC50 of strontium in the copepods (Cyclops abyssorum and Eudiaptomus padanus) is $300 \mathrm{mg} / \mathrm{L}$ and $180 \mathrm{mg} / \mathrm{L}$ respectively. Cladoceran sensitivity to strontium is also moderate $(75 \mathrm{mg} / \mathrm{L}, 48-\mathrm{h} \mathrm{LC50}$ ) (Baudouin and Scoppa 1974).

\subsubsection{Toxicity of Strontium in Terrestrial Biota}

\section{Plants}

See Section 2.1 for a review of the radiation toxicity of strontium.

\section{Invertebrates}

See Section 2.1 for a review of the radiation toxicity of strontium.

\section{Amphibians/Reptiles}

See Section 2.1 for a review of the radiation toxicity of strontium.

\section{Mammals}

The strontium ion has a low order of toxicity (Venugopal and Luckey 1978). Moderate to large doses are required to cause nausea, diarrhea, electrocardiographic changes, and death due to respiratory paralysis (Venugopal and Luckey 1978). Oxides and hydroxides of strontium are moderately caustic compounds. The oral LOAEL of strontium dichloride hexahydrate in rats is $405 \mathrm{mg} / \mathrm{kg}$. Oral ingestion of strontium fluoride results in an oral LD50 in rats of $10,600 \mathrm{mg} / \mathrm{kg}$. However, the 
radioisotope strontium-90 is highly dangerous, and the radiation hazard of strontium-90 is well established (see Section 2.1 for a summary of ionizing radiation effects). Because strontium is a metabolic analog of calcium, strontium-90 is readily absorbed from the lung, gastrointestinal tract, or bloodstream (dermal exposure). The strontium that is retained in the body, in large part, is deposited in the bone. Therefore, exposure to strontium-90 via any exposure route results in a high incidence of neoplasia on bone and related tissues (Harley 1991). Chronic intake of strontium-90 in dogs produced a high incidence of tumors also, but tumor production was low in miniature swine receiving similar doses. Tumorogenicity has also been observed in wild rodents. A muskrat from White Oak Lake that had more than $1 \mu \mathrm{c}$ of strontium per gram of bone, a total body burden of nearly $100 \mu \mathrm{Ci}$ (Krumholz and Rust 1954), displayed advanced osteogenic sarcoma with metastasized cells to both kidneys and lungs. Bone sarcoma generation does not fit a linear dose-response relationship over a wide dose range. Low levels of exposure are better fit by sigmoid dose-response relationships (Mays and Lloyd 1972).

Exposure of humans to strontium salts has also been shown to cause a reduction in the activity of the neurotransmitter, aceytlcholine, and the enzyme cholinesterase. This reduction in activity has not been measured in other mammals. Impaired tooth development in growing animals has been documented at exposures of about $0.4 \mathrm{mg}$ strontium $/ \mathrm{kg}$ (Lewis 1992).

Immunological Effects of Strontium Exposure. See Section 2.1 for a review of the radiation toxicity of strontium.

Reproductive Effects of Strontium Exposure. In addition to the radiation effects of radiostrontium on reproduction, strontium can have a chemical toxicity related to the reproductive system of mammals. Strontium salts have been shown to cause changes in the prostate, seminal vesicle, Cowper's gland, and accessory glands of rats. The LOAEL was $400 \mathrm{mg} / \mathrm{kg}$ as strontium chloride hexahydrate (NIOSH 1987).

Carcinogenic and Genotoxic Effects of Strontium Exposure. See Section 2.1 for information on the radiation hazard of strontium in mammals.

Biomarkers of Strontium Exposure/Effect. The strontium/calcium ratio is relatively constant and can be used to estimate dietary intakes and body burdens of strontium. Dietary intake can be estimated from the strontium/calcium ratio in urine (Comar et al. 1964). The observed ratio urine/diet can be somewhat variable, but generally it is accepted to be 0.84 (Comar 1965). The strontium/ calcium ratio may be a better parameter for estimating uptake because it is less variable than that for urine; however, the urine value reflects the strontium actually absorbed from the diet of the animal. Teeth and hair have also been used to estimate body burden (Rosenthal et al. 1963). Because a large amount of strontium is transferred from the diet of a male deer to the developing antlers, the antlers have been considered for use as indicators of strontium-90 in forage consumed by deer (Rickard et al. 1974). 
Strontium Toxicokinetics: Metabolism and Distribution. After radiostrontium is ingested, about $18 \%$ (it ranges from $5 \%$ to $25 \%$ ) is absorbed into the body from the diet into the gastrointestinal tract; the rest is excreted unabsorbed in the feces. Excretion of the absorbed strontium in feces is $16 \%$, with up to $96 \%$ excreted in the urine. The absorbed strontium is deposited in bone; distributed in an exchangeable pool comprised of soft tissues, bone surface, plasma, etc.; or excreted in feces (up to 16\%) and urine (up to 96\%) (Comar et al. 1964; Dolphin and Eve 1963). Accumulator organs include the bone, aorta, trachea, and lower gastrointestinal tract (Shacklette et al. 1978). The biological half-life of strontium-90 in mammals can be estimated using the equation:

$$
\text { Half-Life }=107.4 \text { (Body Weight) })^{0.2612}
$$

as reported by Reichle et al. (1970).

\section{Birds}

Radiostrontium levels of up to 1700 and $560 \mathrm{pCi} / \mathrm{kg}$ ash of the eggshells and inner egg contents, respectively, have been found in Canada goose eggs on the Hanford Site (Rickard and Sweany 1977). No impacts on clutch size, hatching success, viability of the young, or population parameters have been associated with these levels of contamination when compared to uncontaminated goose populations.

\subsection{Bioconcentration Factors and Trophic Transfer Coefficients}

As an alkaline earth metal, strontium is chemically reactive, commonly forming soluble salts of carbonates, sulfates, and chlorides. It thus is mobile in ecosystems, readily enters food chains, and deposits in calcium-containing tissues. However, tissue concentrations of strontium do not appear to increase with trophic level. This is probably related to metabolic control of strontium uptake by calcium.

\subsubsection{Strontium Transfer in Aquatic Food Chains}

The uptake of strontium-90 from sediment or soil to plants and from plants to animals is affected by the presence of calcium in the systems. The "observed ratio" described by Comar et al. (1956) relates the amount of strontium-90 and calcium in a sample to the amount of the radionuclide and competing element in the precursor. This empirically determined relationship has proven to be consistent and has been successfully applied to modeling the passage of strontium- 90 through food webs 
(Comar and Wasserman 1960; Comar 1965). Most of the reported observed ratios have been determined for food chains leading to human consumers. Those ratios potentially applicable to wildlife exposure are listed in Table 6.1.

The concentration of strontium in the bone and muscle of brown trout was inversely related to calcium concentration of the water (Templeton and Brown 1964). The observed ratio for muscle/ water varied from 0.53 to 1.00 as the calcium level in the water varied from 0.3 to $100 \mathrm{mg} / \mathrm{L}$ (Templeton and Brown 1963). In the absence of site-specific data, recommended default values for the water-based bioconcentration factor for strontium in the flesh of freshwater fish are 5 (NRCC 1983), 800 for fish in water of low mineral content, and 2 for fish in water of high mineral content (CSA 1987). Myers et al. (1989) recommended default values of 180 for water containing $1 \mathrm{mg} / \mathrm{L}$ calcium and 0.7 for water containing $100 \mathrm{mg} / \mathrm{L}$ calcium. Poston and Klopfer (1986) recommended a default value of 100 . The general aquatic concentration factors for strontium are listed in Table 6.2.

Higher concentration ratios than those compiled by Reichle et al. (1970a, 1970b) have been observed in black crappies (Pomoxous nigro-maculatus) and bluegills (Lepomis m. macrochirus). These species concentrated radiostrontium in amounts 20,000 to 30,000 times that found in the water (Buchsbaum 1958). In contrast, Carraca et al. (1990) found no significant biomagnification of strontium concentrations between predator and prey. In fish, the concentration of strontium was proportional to the size of the body, probably because most of the strontium was found in scales and bones. Concentration factors for strontium in the trophic chains of several streams studied by Carraca et al. (1990) are listed in Table 6.3.

Table 6.1. Observed Ratios Reported for Strontium/Calcium Transport in Food Webs (CRC 1982)

\begin{tabular}{|c|c|c|}
\hline System & Observed Ratio & Comments \\
\hline Plant tissue/soil & $0.9-1.0$ & Dependent on plant part \\
\hline Fish muscle/water & $0.5-1.0$ & Dependent on $[\mathrm{Ca}+2]$ in water \\
\hline Fish bone/water & 0.5 & \\
\hline Poultry bone/diet & 0.6 & \\
\hline Egg yolk/diet & 0.6 & \\
\hline Egg white/diet & 1.5 & \\
\hline Mammalian bone/diet & $0.14-0.57$ & Various species \\
\hline
\end{tabular}


Table 6.2. Concentration Factors for Strontium in the Aquatic Food Chain (Reichle et al. 1970a, 1970b; Horsic et al. 1982)

\begin{tabular}{llc}
\multicolumn{1}{c}{ Trophic Level } & \multicolumn{1}{c}{ Consumer Type } & Concentration Factor \\
Algae and higher plants & & $10-3000$ \\
Invertebrates & $\begin{array}{l}\text { Saprovore (detritus-feeder) } \\
\text { Herbivore } \\
\text { Camivore }\end{array}$ & $10-4000$ \\
& $\begin{array}{l}\text { Omnivore } \\
\text { Fish }\end{array}$ & 1 \\
& Camivore & $1-150$
\end{tabular}

\subsubsection{Strontium Transfer through Terrestrial Food Chains}

Absorption of strontium from soil is influenced by the clay content, organic content, $\mathrm{pH}$, moisture level, concentration of electrolytes and, in particular, the calcium content of the soil. In general, conditions that cause shallow root development tend to increase strontium-90 uptake (Comar 1965). Strontium uptake is greatest from soils of low calcium content. Plant crops assimilate from $0.2 \%$ to 3\% of the strontium in the soil (Comar 1965; Menzel 1963). As a general rule, if $1 \mathrm{mCi}$ of strontium$90 / \mathrm{km}^{2}$ is present in the soil, plants will assimilate about $1.1 \mathrm{pCi}$ of strontium-90/g of calcium (Evans and Dekker 1962).

Strontium is greatly reduced, relative to plant levels, in whole-body concentration in insects and other invertebrates. A concentration factor of about 0.1 has been observed for second-order consumers and predators (excluding species with calcified exoskeletons) (Reichle et al. 1970a, 1970b). "Calcium sink" invertebrates (e.g., millipedes, isopods, snails) concentrate strontium by factors greater than 150 (Reichle et al. 1969). Assimilation of strontium-90 from detritus is low (77\%) because it is incorporated into poorly digestible tissue structures (Reichle et al. 1970a, 1970b). The general terrestrial concentration factors for strontium are listed in Table 6.4.

An experimentally determined concentration factor [strontium concentration in the bird (g)/strontium concentration in water (ml)] of 1500 (bone) for coot (Fulica sp.) was reported by Hanson and Kronberg (1956). Feeding habits influence the uptake of strontium into aquatic bird tissues. The highest concentrations of strontium were found in shorebirds feeding on insects and larvae. The dabbling ducks had intermediate levels in their bone tissue, and fish-eating birds had the lowest strontium burden of feeding habits of aquatic birds (Silker 1958). The transfer coefficient for strontium from the diet into milk of cows, goats, and pigs as related to the calcium content of the diet 
Table 6.3. Strontium Bioconcentration and Transfer Factors for Stream-Dwelling Organisms (Carraca et al. 1990)

\section{Trophic Level}

Water to benthic animals

Benthic animals to fish

Boce

Carp

Barbel

Goldfish

Water to fish(b)

Boce

Carp

Barbel

Goldfish

Water to seston

Seston to fish

Boce

Goldfish

Barbel

Water to zooplankton

Seston to zooplankton

Zooplankton to fish

Boce

Carp

Goldfish

Barbel

\section{Concentration}

Eactor $(d x w t)^{(a)}$

$26-53$

Transfer Factor

$7-11^{(c)}$

21

7-10

12

293 - 390

541

$248-365$

631

$227-345$

0.91 .7

1.6

2.8

$0.7-1.6$

259-278

$0.8-1.2$

(a) Calculated concentration factors on dry wt. basis. To convert to wet weight, the dry wt/wet weight ratio is: benthic animals $=0.150$, phytoplankton $($ seston $)=0.138 ;$ zooplankton $=0.100$; boce $=0.257$; barbel $=0.26 ;$ carp $=0.231$, goldfish $=0.281$.

(b) Chondrostoma polypis (boce); Cyprinus carpio (carp); Carassius auratus (goldfish); Barbus bocagei (barbel).

(c) transfer factor close to 1 when only edible tissue is considered. 
Table 6.4. Concentration Factors for Strontium in the Terrestrial Food Chain (Reichle et al. 1970a, 1970b)

\begin{tabular}{llc} 
Trophic Level & $\begin{array}{c}\text { Consumer } \\
\text { Type }\end{array}$ & $\begin{array}{c}\text { Concentration } \\
\text { Factor }\end{array}$ \\
\cline { 3 - 3 } Plants & & 1.0 \\
Invertebrates & Saprovore( $)$ & $<0.1$ \\
& Herbivore & 0.1 \\
& Camivore & 0.1
\end{tabular}

Mammals

Herbivore

$0.5-4.5$

Omnivore

Carnivore

(a) Detritus-Feeder.

is 0.1 (range 0.08-0.16) (Comar 1965). The observed ratio value for body/diet of 0.2-0.5 has been reported for cattle, goats, sheep, and pigs. Observed ratio values for egg yolk, eggshell, and femur in chickens was 0.6 (Comar 1965). 


\subsection{Cobalt-60}

\subsection{Cobalt-60 Toxicity}

The hazard of cobalt-60 exposure in aquatic systems is largely related to the radiation toxicity of the radionuclide. Section 2.1 reviews the impacts of ionizing radiation on biota. Available information on the chemical toxicity of cobalt to various trophic levels is summarized below.

\subsubsection{Cobalt-60 Toxicity in Aquatic Biota}

Divalent cobalt is highly toxic to zooplanktonic species. Acute toxicity (48-h LC50) of cobalt (II) to 2 copepods was $15.5 \mathrm{mg} / \mathrm{L}$ for Cyclops abyssorum and $4.0 \mathrm{mg} / \mathrm{L}$ for Eudiaptomus padamus. The 48-h LC50 for Daphnia hyalina was $1.32 \mathrm{mg} / \mathrm{L}$ (Baudouin and Scoppa 1974).

See Section 2.1 for a review of the radiation toxicity of cobalt- 60 .

\subsubsection{Cobalt-60 Toxicity in Terrestrial Biota}

The toxicity of cobalt in terrestrial biota is given below.

\section{Plants}

The threshold toxicity for lettuce seedlings grown in a hydroponic solution was $13 \mu \mathrm{eq} / \mathrm{L}$ $(0.38 \mathrm{mg} / \mathrm{L})$. Growth was inhibited by $50 \%$ at $62 \mu \mathrm{eq} /(1.83 \mathrm{mg} / \mathrm{L})$, and cobalt was lethal to the seedlings at $1,500 \mu \mathrm{eq} / \mathrm{L}(44.25 \mathrm{mg} / \mathrm{L})($ Berry 1978). Morphological abnormalities of floral parts occurred at radiation levels of about $2 \mathrm{R} / \mathrm{d}$ from cobalt -60 and included multiplication and reduction or maiformation of floral parts (Platt 1965).

\section{Invertebrates}

See Section 2.1 for a review of the radiation toxicity of cobalt -60 .

\section{Amphibians/Reptiles}

See Section 2.1 for a review of the radiation toxicity of cobalt- 60 .

\section{Mammals}

Cobalt is an essential element and is found in vitamin B12 (0.0434 $\mu \mathrm{g}$ of cobalt/ $\mathrm{gg}$ vitamin B12). Ingestion of excessive amounts of cobalt results in polycythemia (excess formation of red blood cells) in most mammals. This response, in part, is caused by the creation of intracellular hypoxia and 
results in an overexertion of the heart and elevated blood pressure (Waldbott 1973). The cardiotoxic effects of cobalt are also related to its antagonistic action toward $\mathrm{Ca}^{+2}$ and the complex-forming ability of cobalt with cellular macromolecules (Goyer 1986). Oral uptake of $26 \mathrm{mg} / \mathrm{kg}$ for 8 weeks following an initial dose of $100 \mathrm{mg} / \mathrm{kg}$ resulted in cardiomyopathy in rats. Vomiting, diarmea, and a sensation of warmth are sublethal responses to cobalt ingestion (Beliles et al. 1978) and are induced in mammals by chronic exposure to $150 \mathrm{ppm}$ cobalt in the diet (Waldbott 1973). The LOAEL for cobalt nitrate was $250 \mathrm{mg} / \mathrm{kg}$ in rabbits; the LD50 in rats was reported to be $434 \mathrm{mg} / \mathrm{kg}$. Oral toxicity of cobalt chloride was $80 \mathrm{mg} / \mathrm{kg}$ in rats and $55 \mathrm{mg} / \mathrm{kg}$ in guinea pigs. The LOAEL for cobalt chloride in rabbits was $1272 \mathrm{mg} / \mathrm{kg}$ (NIOSH 1987).

Inhalation of powdered cobalt produces chronic lung changes that evolve into pulmonary fibrosis (Waldbott 1973). Miniswine exposed to $0.1 \mathrm{mg} / \mathrm{m}^{3}$ cobalt metal dust by inhalation for 3 months showed marked decrease in lung compliance and an increase in collagen in the pulmonary alveolar septa (Kerfoot et al. 1975).

Irradiation of wild rodents with cobalt-60 resulted in LD50/30 values ranging from 525 to $1069 \mathrm{rad}$. These values are elevated over those for laboratory rodents that have LD50/30 values of 330 to 900 rad (Dunaway et al. 1969). Weights of irradiated rodents receiving greater than or equal to $1000 \mathrm{rad}$ decreased. The radiation toxicity threshold (i.e., $95 \%$ survival rate) was an exposure above 450 rad for all species of wild rodents (O'Farrell 1969).

Immunological Effects of Cobalt Exposure. Cobalt can cause an allergic dermatitis in animals (Schwartz 1947). Sensitization of the respiratory tract also occurs in mammals (Kerfoot et al. 1975).

Reproductive Effects of Cobalt Exposure. Pregnant mice exposed to cobalt chloride at a LOAEL of $25 \mathrm{mg} / \mathrm{kg}$ produced young with craniofacial abnormalities. In rats, an LOAEL exposure of $30 \mathrm{~g} / \mathrm{kg}$ resulted in post-implantation mortality and fetotoxity (NIOSH 1987).

Carcinogenic Effects of Cobalt Exposure. In addition to radiation-induced carcinogenicity, there is a chemical carcinogenicity associated with cobalt as well. Depending on the route of exposure and the form of cobalt, the tumorigenic exposures observed in rats ranged from $75 \mathrm{mg} / \mathrm{kg}$ to $4530 \mathrm{mg} / \mathrm{kg}$ (NIOSH 1987).

Genotoxicity. See Section 2.1 for a review of the radiation toxicity of cobalt-60.

Biomarkers of Cobalt Exposure/Effect. Fat tissue contains the highest concentration of cobalt, and heart, liver, and hair/fur also concentrate cobalt, but to a much smaller degree (Beliles 1978). However, no data are available on the relationship between cobalt concentrations in these tissues and the exposure of the organism or any toxic effects. Blood and urine levels may be used to estimate "above normal levels." 
Cobalt Toxicokinetics: Metabolism and Distribution. Cobalt salts are well absorbed after oral ingestion. However, increased uptake above $0.004 \mathrm{mg} / \mathrm{kg}$ does not result in accumulation in humans (Beliles 1978). Significant species differences in excretion rates have been observed in mammals. In man and dogs, about $80 \%$ of the absorbed cobalt is excreted in the urine, and $15 \%$ of the remaining cobalt is excreted by an entero-hepatic pathway into the feces. In contrast, $80 \%$ of the absorbed cobalt is eliminated in the feces of rats and cattle (Beliles 1978). About $10 \%$ of the cobalt radioactivity is found in the urine of rats, but less than $0.5 \%$ is found in the urine of cattle, indicating a greater initial retention by tissues in ruminants.

\section{Birds}

Radiocobalt levels of up to 5 to $8 \mathrm{pCi} / \mathrm{kg}$ ash and 28 to $39 \mathrm{pCi} / \mathrm{kg}$ ash of the eggshells and inner egg contents, respectively, have been found in Canada goose eggs on the Hanford Site (Rickard and Sweany 1977). No impacts on clutch size, hatching success, viability of the young, or population parameters have been associated with these levels of contamination when compared to uncontaminated goose populations.

\subsection{Bioconcentration Factors and Trophic Transfer Coefficients}

Cobalt is readily accumulated from the environment by aquatic and terrestrial biota. However, trophic transfer is low and no biomagnification of the radionuclide has been reported for either aquatic or terrestrial food chains.

\subsubsection{Cobalt-60 Transfer in Aquatic Food Chains}

The general aquatic concentration factors for cobalt are listed in Table 7.1. Cobalt is slightly more concentrated in invertebrates than in water but is markedly less concentrated in invertebrates than in algae and higher plants (Table 7.1).

Voshell et al. (1985) determined the uptake of cobalt at the various trophic levels of an aquatic insect community. Using this information in conjunction with the reported water and sediment concentrations of cobalt, the transfer coefficients at each trophic level were calculated. The algae and plankton concentrated cobalt from water and had transfer coefficients of 11,800 and 20,600 , respectively. Herbivorous insects (coleopteran adults) feeding on the filamentous algae had an algae-toinsect transfer coefficient of 0.1 . The transfer coefficient of saprovores (mayflies and chronomid midges) was 0.04. Saprovore-to-carnivore (damsel flies and dragon flies) transfer was 0.01 . The transfer coefficient for predators (Notonectidae) that consumed only the body fluids of their prey was 0.13. (Note: Voshell et al. (1985) suggest that emergent insects that leave the water as adults could be used as a biomarker of cobalt exposure.) The maximum transfer factors reported for fish that fed on cobalt-contaminated crustaceans (Gammaras pulex), midge larvae (Chrionomus sp.), and the soft tissue of snails (Lymnaea stagnalis) ranged from 0.012 to 0.051 (Baudin et al. 1990). Midge 
Table 7.1. Concentration Factors for Cobalt in the Aquatic Food Chain

\begin{tabular}{|c|c|c|}
\hline Trophic Level & $\begin{array}{c}\text { Concentration } \\
\text { Factor }\end{array}$ & Reference \\
\hline Algae and Higher Plants & $2500-6200$ & Reichle et al. 1970a, 1970b \\
\hline \multicolumn{3}{|l|}{ Invertebrates } \\
\hline Saprovore(a) & 325 & Reichle et al. 1970a, 1970b \\
\hline \multicolumn{3}{|l|}{ Fish } \\
\hline \multicolumn{3}{|l|}{ Rainbow Trout (Oncorhynchus mykiss) } \\
\hline eggs & 7.0 & Kimuru and Honda 1977b \\
\hline fry & 11.0 & Kimuru and Honda 1977b \\
\hline fingerlings & 6.5 & Kimuru and Honda 1977b \\
\hline Smelt (Osmerus mordax) & $48-1000$ & Vanderploeg et al. 1975 \\
\hline Spottail Shiner (Notropis hudsonius) & $220-630$ & Vanderploeg et al. 1975 \\
\hline Alewife (Alosa pseudoharengus) & $190-420$ & Vanderploeg et al. 1975 \\
\hline Trout-Perch (Percopsis omiscomaycus) & 130 & Vanderploeg et al. 1975 \\
\hline Fathead Minnow (Pimephales promelas) & 190 & Harrison et al. 1990 \\
\hline Lake Trout (Salvelinus namaycush) & 11 & Harrison et al. 1990 \\
\hline
\end{tabular}

(a) Detritus-Feeder.

larvae were reported to concentrate cobalt-60 from water by a factor of 30 . Transfer of cobalt to larvae from sediment was low (0.62), but the sediment constituted a permanent exposure source to the larvae compared to the very transitory concentrations of cobalt in water. Virtually the entire amount of the cobalt-60 in an aquatic system was fixed rapidly to the sediment (Baudin and Nucho 1992; Lambrechts and Foulquire 1986). The sediment-to-plant transfer coefficient was 0.29 in a stream contaminated with cobalt (Stewart et al. 1992). The organic content of the sediment markedly influenced the uptake of cobalt- 60 by midge larvae. An increase in the organic content of the sediment can lead to a two-fold increase in cobalt uptake (Baudin and Nucho 1992). The midge larvae daily ingested an amount of sediment equivalent to $9 \%$ of their dry weight (Gerking et al. 1976). The trophic transfer of cobalt-60 from planktonic algae to midge larvae was low, 0.0045 , and did not lead to bioamplification of the radionuclide (Baudin and Nucho 1992).

In the absence of site-specific data, recommended default values for the water-based bioconcentration factor for cobalt in the flesh of freshwater fish are 20 (NRCC 1983). A default bioconcentration factor of 1000 is recommended for fish in water of low mineral content and a default value of 100 is recommended for fish in water of high mineral content (CSA 1987). Myers et al. (1989) recommend a default value of 30 for eutrophic conditions. 


\subsubsection{Cobalt Transfer Through Terrestrial Food Chains}

Cobalt progressively decreases in concentration through invertebrate food chains, generally averaging one-half the concentration of plants after two trophic exchanges (Reichle and Crossley 1969). The general terrestrial concentration factors for cobalt are listed in Table 7.2.

Table 7.2. Concentration Factors for Cobalt in the Terrestrial Food Chain (Reichle et al. 1970a, 1970b)

$\begin{array}{llc}\text { Trophic Level } & \begin{array}{c}\text { Consumer } \\ \text { Type }\end{array} & \begin{array}{c}\text { Concentration } \\ \text { Factor }\end{array} \\ \text { Plants } & \text { Saprovore(a) } & 1.0 \\ \text { Invertebrates } & \begin{array}{l}\text { Herbivore } \\ \text { Carnivore }\end{array} & 0.4 \\ & \text { Herbivore } & 0.5 \\ \text { Mammals } & & 0.3\end{array}$

(a) Detritus-Feeder. 


\subsection{Chromium}

\subsection{Chromium Toxicity}

Little is known about the relationship between concentrations of chromium in a given ecosystem and the biological effects on the component organisms. The same elemental concentration of chromium has a wide variety of mobilities and reactivities depending on the physical and chemical state of the ion. Therefore, the observed effects of chromium exposure vary widely. In addition, species' sensitivity to chromium differs greatly, even among closely related species (Steven et al. 1976). The toxicity of chromium ions is highly dependent on oxidation state. Only the trivalent and hexavalent chromiums are biologically significant. Trivalent chromium is the only form of chromium found in biological material. Trivalent chromium does not readily cross cell membranes, and it forms stable complexes with serum proteins. As a result, it has a low overall toxicity potential and is relatively inactive in vivo. In contrast, hexavalent chromium is readily taken up by living cells and is highly active in diverse biological systems. Although the known harmful effects of chromium in animals are attributed to exposure to the hexavalent form, it is the trivalent form that is ultimately damaging as it is formed from the reduction of hexavalent chromium and complexes with intracellular macromolecules.

\subsubsection{Toxicity of Chromium in Aquatic Biota}

The toxicity of chromium in aquatic biota is presented in the following sections.

\section{Aquatic Plants}

Hexavalent chromium is toxic to algae at concentrations of less than $10 \mathrm{mg} / \mathrm{L}$ (Shacklette et al. 1978). Growth of most species tested was reduced at concentrations of 10 to 45 ppb hexavalent chromium. Effects were most pronounced in water of a low alkalinity (Eisler 1985). Common duckweed (Lemna minor) is the most sensitive aquatic plant tested exhibiting reduced growth in water containing $10 \mathrm{ppb}$ hexavalent chromium (Mangi et al. 1978). The LC50s for aquatic macrophytes range between 2.5 and $25 \mathrm{mg} / \mathrm{L}$ (Mangi et al. 1978).

\section{Invertebrates}

LC50 values for rotifers and crustaceans range between 0.4 and $67 \mathrm{mg} / \mathrm{L}$. Hexavalent chromium was toxic to snails at 17 to $41 \mathrm{mg} / \mathrm{L}$ (Buikema et al. 1974; EPA 1980; Murti et al. 1973; Jouany et al. 1982). Reduced fecundity was observed in Dapnia magna at $10 \mathrm{ppb}$ hexavalent chromium and $44 \mathrm{ppb}$ trivalent chromium after 32 days of exposure (EPA 1980). Exposure to $1.8 \mathrm{mmol}$ chromium solution resulted in a $100 \%$ death rate of the freshwater trematode, Schistosoma haematiobium, in $1 \mathrm{~h}$. 
Sporocyst formation was also inhibited, and the number of miracidia penetrating snails (intermediate host) was reduced by $50 \%$ (Wolmarans et al. 1988). The acute toxicity values for aquatic invertebrates are listed in Table 8.1.

\section{Fish}

In general, adverse effects of chromium to sensitive fish species have been documented at $10 \mu / \mathrm{L}(\mathrm{ppb})$ of hexavalent chromium and $30 \mu \mathrm{g} / \mathrm{L}$ of trivalent chromium in freshwater (Eisler 1985). Growth rates of rainbow trout and chinook salmon fingerlings were reduced in fish exposed to 16 to $21 \mathrm{ppb}$ hexavalent chromium for 14 to 16 weeks (EPA 1980). The half-life of chromium in rainbow trout was 1 day for the short-term component (34\% of total chromium) and 25.6 days for the longterm component (Van der Putte et al. 1981). At a concentration of $0.23 \mathrm{ppm}$ hexavalent chromium for 4 weeks, salinity tolerance and serum osmolality were impaired in migrating coho salmon (Sugatt 1980). The survival rate of alevins and juveniles of coho salmon was significantly reduced by exposure to $0.2 \mathrm{mg} / \mathrm{L}$ chromium (Oson 1958). Reproductive impairment in fathead minnows was observed after 10 months of exposure to $2.0 \mathrm{mg} / \mathrm{L}$ chromium (Pickering and Henderson 1966). The NOAEL and LOAEL for several species of freshwater fish are listed in Table 8.2. 
Table 8.1. Acute Toxicity of Hexavalent and Trivalent Chromium in Aquatic Invertebrates

\begin{tabular}{|c|c|c|c|c|}
\hline Specie: & $\begin{array}{l}\text { Water Hardness } \\
\left(\mathrm{meC} \mathrm{CaO}_{2} \mathrm{M}\right)\end{array}$ & $\begin{array}{l}\text { LCSO } \\
\text { (m:/ })\end{array}$ & $\begin{array}{c}\text { Test } \\
\text { Duration }\end{array}$ & Reference \\
\hline
\end{tabular}

Rotifers

Philodena acuticornis

25

81

Mollusks

Physa heteroostropha

(Snail)

Crustaceans

Gammarus pseudolimnacus

(Amphipod)

Machrobrahium lamarrei

(Prawn)

Daphria magna

(Cladoceran)

Dapnia hyalina

(Cladoceran)

Cyclops abyssorum

(Copepod)

Eudaptomus padanus

Insects

Acroneuria bycurias

(Stonefly)

Hydropsyche betteri

(Caddisfly)

Ephemerella subvaria

(Mayfly)

45

171

65

65

65
32

32

16

3.1

15

17.3

31.6-40.6

67

1.8

0.4

0.002

10.0

10.1

$48 \mathrm{~h}$

$7 d$

7 d

$7 d$
Warnick and Bell 1961

Warnick and Bell 1961

EPA 1980

EPA 1980

EPA 1980

Murti et al. 1983

Juoany et al. 1982

Baudouin and Scoppa 1974

Baudouin and Scoppa 1974

Baudouin and Scoppa 1974

Warnick and Bell 1961 
Table 8.1. (contd)

\begin{tabular}{|c|c|c|c|c|}
\hline Species & $\begin{array}{l}\text { Water Hardness } \\
\text { (me } \mathrm{CaCO}_{3}(\mathrm{l}) \text { ) }\end{array}$ & $\begin{array}{c}\text { LCSO } \\
\text { (me/h) } \\
\end{array}$ & $\begin{array}{l}\text { Test } \\
\text { Duration }\end{array}$ & Reference. \\
\hline \multicolumn{5}{|l|}{ Trivalent } \\
\hline \multicolumn{5}{|l|}{ Mollusks } \\
\hline $\begin{array}{l}\text { Amnicola sp. } \\
\text { (Snail) }\end{array}$ & & 8.4 & $96 \mathrm{~h}$ & EPA 1980 \\
\hline \multicolumn{5}{|l|}{ Annelids } \\
\hline Nais sp. & & 9.3 & $96 \mathrm{~h}$ & EPA 1980 \\
\hline \multicolumn{5}{|l|}{ Arthropods } \\
\hline \multirow[t]{4}{*}{ Dapnia magna } & 48 & 2.0 & $96 \mathrm{~h}$ & EPA 1980 \\
\hline & 52 & 16.8 & $96 \mathrm{~h}$ & EPA 1980 \\
\hline & 99 & 27.4 & $96 \mathrm{~h}$ & EPA 1980 \\
\hline & 195 & 51.4 & $96 \mathrm{~h}$ & EPA 1980 \\
\hline Gammarus sp. & & 3.2 & $96 \mathrm{~h}$ & EPA 1980 \\
\hline Insects (4 spp.) & & $2.0-64.0$ & $96 \mathrm{~h}$ & EPA 1980 \\
\hline
\end{tabular}

Table 8.2. NOAELs and LOAELs Reported for Hexavalent and Trivalent Chromium in Freshwater Fish

$$
\text { Species }
$$

Hexavalent

Rainbow Trout (Oncorhynchus mykiss)

Brook Trout (Salvelinus fontinalis)

Fathead Minnow (Pimephales promelas)

Channel Catfish (Ictalurus punctatus)

Bluegill (Lepomis macrochirus)

White Sucker (Catostomus commersoni)

Northem Pike (Esox lucius)

Walleye (Stizostedion vitreum)

\section{Trivalent}

Rainbow Trout (Oncorhynchus mykiss)

Fathead Minnow (Pimephales promelas)

$\begin{array}{ll}\text { NOAEL } & \text { LOAEL } \\ (\mu \mathrm{g} / L) & (\mu \mathrm{g} / \mathrm{L})\end{array}$

$51-200$

200

1000

150

522

290

538

$>2161$

105-350

350

3950

305

1122

538

963

30

157

1400

EPA 1980

EPA 1980 
Acute lethality (LC50) of chromium to fish varies between 17 and $171 \mathrm{mg} / \mathrm{L}$ for most fish species (Table 8.3). Stickelback (Gasterosteus aculeatus) appear to be more sensitive than other freshwater fish to chromium toxicity. Concentrations of $1.0 \mathrm{mg} / \mathrm{L}$ or more are lethal to this species (Anderson 1944; Murdock 1953; Jones 1939). Reported LC50 values for hexavalent and trivalent chromium are listed in Table 8.3.

\subsubsection{Toxicity of Chromium to Terrestrial Biota}

The toxicity of chromium to terrestrial biota is described below.

\section{Plants}

Chromium is beneficial, but not essential, to growth in higher plants. Residues in plants seldom exceed a few ppm. Growth inhibition noted in certain plant species on "serpentine soils" has been attributed to high chromium levels in the soils (Brooks 1972). Plants grown in these soils typically show symptoms of toxicity when concentrations of chromium in the leaves reach 4 to $8 \mathrm{ppm}$ (dry weight) in corn leaves, $252 \mathrm{ppm}$ in oat leaves, and 18 to $24 \mathrm{ppm}$ in tobacco leaves or 375 to $400 \mathrm{ppm}$ in tobacco roots (NAS 1974). Soil infertility has been associated with 1000 to $3900 \mathrm{ppm}$ chromic acid in Maryland (Vokal et al. 1975) and with 2\% to 3\% chromic oxide in "poison spots" in Oregon (McMurtry and Robinson 1938). In native foliage, concentrations as high as $1390 \mathrm{ppm}$ dry weight did not show adverse biological effects (Eisler 1985). Chromium concentrations in excess of $1 \mathrm{ppm}$ in aqueous solution may inhibit germination of the seed and growth of roots and shoots (Towhill et al. 1978). Chromium salts, particularly hexavalent forms, are toxic to plants in very low concentrations. Bowen (1979) reports plant toxicity levels of 0.5 to $10 \mathrm{ppm}$. Severe plant damage occurs when chromium reaches levels of 9 ppm in plant ash (Brooks 1972).

Potted tobacco plants are sensitive indicators of chromium contamination, concentrating chromium rapidly and showing significant leaf growth reduction. They have been used as indicators of chromium contamination (Taylor and Parr 1978).

\section{Invertebrates}

Little information is available on invertebrate responses to chromium exposures. Concentrations of 10 to $15 \mathrm{ppm}$ of hexavalent chromium in irrigation water applied to agricultural land were lethal to two species of earthworms by 58 to 60 days (Soni and Abbasi 1981; Abbasi and Soni 1983).

\section{Amphibians/Reptiles}

No information was found regarding the toxicity of chromium to amphibians and reptiles. 
Table 8.3. Acute LC50 Values Reported for Chromium in Freshwater Fish

\begin{tabular}{cll} 
Species & $\begin{array}{l}\text { LC50 } \\
(\mathrm{mg} / \mathrm{L})\end{array} \quad \begin{array}{l}\text { Exposure } \\
\text { Period }\end{array}$ \\
\hline
\end{tabular}

Hexavalent

Fathead Minnow

(Pimephales promelas)

33

17.6

27.3

Goldfish

(Carassius auratus)

Bluegill

(Lepomis macrochirus)

Largemouth Bass

(Microterus salmoides)

170

0.2

133

118

95

94

69

(Oncorhynchus mykiss)

Brook Trout

(Salvelinus fontinalis)

Trivalent

Fathead Minnow

(Pimephales promelas)

65

27

59

$96 \mathrm{~h}$

$96 \mathrm{~h}$

$96 \mathrm{~h}$

$96 \mathrm{~h}$

$96 \mathrm{~h}$

Pickering and Henderson 1966

NAS 1974

Pickering and Henderson 1966

Pickering and Henderson 1966
$96 \mathrm{~h}$

continuous

$96 \mathrm{~h}$

$96 \mathrm{~h}$

$48 \mathrm{~h}$

$80 \mathrm{~h}$

$96 \mathrm{~h}$

Benoit 1976

Trama and Benoit 1960

Surber 1965

Pickering and Henderson 1966

Pickering and Henderson 1966

Fromm and Shiffman 1958

Fromm and Shiffman 1958
Benoit 1976
$96 \mathrm{~h}$

$96 \mathrm{~h}$

$96 \mathrm{~h}$

Bluegill

(Lepomis macrochirus)

72

Pickering and Henderson 1966

NAS 1974 


\section{Mammals}

The toxic effects of chromium on mammals are described in the following sections.

Toxic Response from Oral Exposure. Hexavalent chromium compounds are much more acutely toxic than trivalent compounds. A lethal single oral dose of hexavalent chromium in young rats was $130 \mathrm{mg} / \mathrm{kg}$. However, $650 \mathrm{mg} / \mathrm{kg}$ of trivalent chromium was not toxic to rats (Samitz et al. 1962). Soluble hexavalent compounds (e.g., chromic and zinc chromates, calcium chromate, lead chromate, barium chromate, strontium chromate) are about 100- to 1000-fold less toxic than insoluble hexavalent compounds (e.g., chromic acid, the monchromates and dichromates of sodium, potassium, ammonium, liththium, cesium and rubidium) with oral toxicities of about $1500 \mathrm{mg} / \mathrm{kg}$. These compounds, however, have an intermediate toxicity by dermal application of about 200 to $350 \mathrm{mg} / \mathrm{kg}$ (Samitz et al. 1962). Large doses $(15 \mathrm{mg} / \mathrm{kg}$ ) of both trivalent and hexavalent chromium compounds caused acute tubular necrosis in laboratory animals when administered paraenterally (Kelly et al. 1982; Laborda et al. 1986; Mathur et al. 1977; Biber et al 1968; Kramp et al. 1974). (Absorption from the gastrointestinal tract was low for both oxidation states.) Dietary exposure of mice for three generations to $20 \mathrm{ppm}$ chromium oxide did not affect mortality, morbidity, growth, or fertility (Hutcheson et al. 1975). Levels up to $276 \mathrm{ppm}$ chromium in the diet of growing rats for 20 weeks did not cause adverse effects in the animals (Mertz 1975; Mertz and Roginski 1975). Cats tolerated $1000 \mathrm{mg}$ trivalent chromium without adverse effects (Venugopal and Luckey 1978). In rats, $1000 \mathrm{ppm}$ dietary hexavalent chromium represented the toxic threshold (Steven et al. 1976). Trivalent chromium in drinking water at a concentration of $5 \mathrm{ppm}$ trivalent chromium over the lifetime of the animals did not cause toxic responses in rats and mice (Schroeder et al. 1964, 1965). However, exposure to $5 \mathrm{ppm}$ hexavalent chromium in drinking water decreased the growth rate of rats (Schroeder 1973). MacKensie et al. (1958) found that $50 \mathrm{ppm}$ hexavalent chromium in drinking water caused liver and kidney damage along with growth depression. Exposure to trivalent chromium at the same level in food did not injure mice (Preston et al. 1976). Water concentrations of $25 \mathrm{ppm}$ chromium as either trivalent or hexavalent chromium did not result in weight loss or pathology in rats (MacKensie et al. 1958). Adverse effects of chromium to sensitive wild mammals have been documented at 5.1 and $10 \mathrm{mg}$ of hexavalent chromium and trivalent chromium, respectively, per $\mathrm{kg}$ of diet (ppm).

The major acute effect from ingested chromium is acute renal tubular necrosis. Chromium exposure at sublethal levels also damages the kidney. Low doses produce necrosis of the proximal convoluted tubule that leads to pronounced agluosuremia, ischemia, and tissue damage (Hook and Hewitt 1986). As the dose is increased, damage is observed throughout the proximal tubule. No studies have been conducted on the renal effects of low-level, long-term exposure to chromium (Wedeen and Qian 1991).

Toxic Response from Inhalation Exposure. Progressive pulmonary fibrosis and alterations in respiratory function can result from long-term exposure to both trivalent and hexavalent chromium compounds (Capodaglio et al. 1975; Sluis-Cremer and du Toit 1968). In rats, inhalation exposure to 
calcium chromate dust at $13 \mathrm{mg} / \mathrm{m}^{3}, 5 \mathrm{~h}$ per day, 5 days per week for life resulted in growth retardation, marked changes in the epithelium of the bronchia, changes in the tracheal submandibular lymph nodes, and atrophy of the spleen and liver after 2 years of exposure (Nettesheim et al. 1971). Cats were unaffected by aerosol exposures of 80 to $115 \mathrm{mg}$ trivalent chromium for $1 \mathrm{~h}$ daily for 4 months. Humans experience strong irritation of nasal membranes at levels as low as $10 \mu \mathrm{g} / \mathrm{m} 3$ even after short exposures (Steven et al. 1976). Inhalation of hexavalent chromium compounds has been linked to kidney and liver damage in humans (Major 1922; Hunter and Roberts 1933).

Toxic Response from Dermal Exposure. Protein complexation accounts for the highly corrosive action in skin, ulcerations, and nasal and respiratory mucous membrane injury by hexavalent chromium (Browning 1969). Entry of chromium through wounds can result in deep ulcerations that penetrate to the underlying bone. The LOAEL for chromic acid, disodium salt, in guinea pigs is $206 \mathrm{mg} / \mathrm{kg}$ by dermal exposure (NIOSH 1987). Uptake of chromium from intact skin is very low. Application of $30,000 \mathrm{ppm}$ hexavalent chromium caused skin lesions or ulcers in guinea pigs, but only if the skin at the site of application was abraded or stripped of its natural oils (Steven et al. 1976). Chromium is a potent skin sensitizer and can induce allergic skin reactions (Wahlberg 1973; Hicks et al. 1979).

Other Toxicity Information. Soluble hexavalent chromium compounds are highly toxic by su!,cutaneous, intraperitoneal, or intramuscular injection (10 to $50 \mathrm{mg} / \mathrm{kg}$ ), but these routes of exposure have little environmental application.

At concentrations greater than $2 \mu \mathrm{M}(0.3 \mathrm{mg} / \mathrm{L})$ chromium is cytotoxic, causing modifications in the cell cycle (Bakke et al. 1984). The toxicity of chromium probably results from its ability to oxidize substances such as gluthione within the cell, producing trivalent chromium (DePamphilis and Cleland 1973; Cleland and Mildvan 1979; Marzilli 1981). The trivalent chromium ions have the ability to form complexes with macromolecules (e.g., proteins and nucleotides) modifying their structure and function (Denniston and Uyeki 1987; Sissoeff et al. 1976; Tamino et al. 1981; Balbi et al. 1981; DePamphilis and Cleland 1973). For example, formation of metallated nucleotides, such as CrATP, inhibits a number of enzyme systems (Danenberg and Cleland 1985; Cleland and Mildvan 1979; DePamphilis and Cleland 1973) resulting in abnormal cellular metabolism.

It should be noted that chromium is an essential element for humans and several species of laboratory animals. Data are incomplete for other organisms (Eisler 1985).

Immunological Effects of Chromium Exposure. Chromium is a potent sensitizer resulting in the induction of allergic skin reactions (Wahlberg 1973; Hicks et al. 1979). The ability of chromium to form very stable complexes with proteins is the probable mechanism of its toxic action in dermatitis and sensitization (Browning 1969).

Reproductive Effects of Chromium Exposure. Sterility in rats was induced at $1250 \mathrm{ppm}$ zinc chromate in the feed. Potassium chromate caused sterility at $5000 \mathrm{ppm}$ (Gross and Heller 1946). 
Spermatogenic cell degeneration was observed in rabbits intraperitoneally injected with $2 \mathrm{mg} / \mathrm{kg}$ of either trivalent chromium or hexavalent chromium daily for 3 to 6 weeks (Behari et al. 1978; Tandon et al. 1979). Little placental transfer of chromium to the embryo occurs, indicating that reported malformations and fetal deaths (lijima et al. 1979; Matsumoto et al. 1976) were likely caused by an action on the uterus or placenta (Leonard et al. 1984). Increased fetal death was observed at an intravenous dose of about $8 \mathrm{mg} / \mathrm{kg}$, and malformations were observed at levels above $15 \mathrm{mg} / \mathrm{kg}$ (Matsumoto et al. 1976). Cleft palates and defects in skeletal ossification were observed in offspring of golden hamsters that received intravenous injections of $5 \mathrm{mg}$ hexavalent chromium $/ \mathrm{kg}$ body weight while pregnant (Gale 1978).

Carcinogenic Effects of Chromium Exposure. Water insoluble hexavalent chromium ions (e.g., chromic and zinc chromates, calcium chromate, lead chromate, bariurn chromate, strontium chromate) are carcinogenic, whereas the soluble forms (e.g., chromic acid, the monochromates and dichromates of sodium, potassium, ammonium, lithium, cesium, and rubidium) are not (Laskin et al. 1969). In contrast, the water-solubilized trivalent forms of chromium have caused cancers in mammals (Hatherhill 1981), but insoluble trivalent chromium is not biologically active (Gale 1978). Tumors of the lungs, nasal cavity, and paranasal sinus have been reported (Lewis 1992). Whether chromium compounds cause cancer at sites other than the respiratory tract is not clear (Casarett and Doulls 1986). Intratracheal administration of $40 \mathrm{mg} / \mathrm{kg}$ of calcium chromate for 34 weeks resulted in tumor formation in the lungs of rats. Lung tumors were also generated by oral uptake of $1600 \mathrm{mg} / \mathrm{kg}$ dipotassium chromate for 62 weeks (NIOSH 1987). Exposure to 500 to $1500 \mu \mathrm{g} / \mathrm{m}^{3}$ of chromate for 6 to 9 years caused respiratory cancer in humans (ACGIH 1986). Dermal exposure to hexavalent chromium for 2 to 3 months resulted in local carcinomas of the muscle and skin in laboratory animals (Steven et al. 1976).

Genotoxicity. At high concentrations, chromium is a mutagen to a wide variety of organisms including plants, insects, microbes, and mammals (Leonard and Lauwerys 1980; Norseth 1981; Hatherhill 1981; Levis and Bianchi 1982; Bianchi et al. 1983; De Floro and Wetterhahn 1989; Hansen and Stem 1986). Chromium genotoxicity is a complex process involving active chromate ion transport across cell membranes, intracellular reduction via reactive $\mathrm{Cr}+5$ and $\mathrm{Cr}+6$ intermediates to stable $\mathrm{Cr}^{+3}$ species, and the binding of trivalent chromium with nucleic acids (Sissoeff et al. 1976; Tamino et al. 1981; Balbi et al. 1981). Although the ultimate mutagen is trivalent chromium, it is hexavalent chromium that produces positive responses in most test systems used to detect genetic effects. Positive responses are noted for trivalent chromium only in non-intact cell systems in which direct interaction with DNA is permitted (Levis and Bianchi 1982). This occurs because trivalent compounds are unable to cross cell membranes, but hexavalent compounds are actively transported across cell membranes and, once in the cell, are reduced to the genotoxic trivalent form. Trivalent chromium interferes with nucleotide biosynthesis, alters the structure of DNA, stimulates DNA repair, and reduces the fidelity of DNA synthesis (Bianchi and Levis 1986; Majone and Leis 1978; Nakamuro et al. 1978; Uyeki and Nishio 1983). A Chinese hamster ovary cell culture exposed to $52 \mathrm{ppb}$ hexavalent chromium showed sister chromatid exchanges and inhibited cell proliferation. Trivalent chromium at $520 \mathrm{ppm}$ did not affect cell proliferation of chromatid exchanges (Uyeki and 
Nishio 1983). The NOAEL was $0.52 \mathrm{ppb} \mathrm{Cr}+6$. Chromosomal rearrangements and aberrations were reported in rabbit cells after exposure to hexavlaent chromium (Hatherhill 1981). Teratogenic effects induced by intravenous exposure to $5 \mathrm{mg}$ hexavalent chromium $/ \mathrm{kg}$ body weight to pregnant golden hamsters included cleft palates and defects in the ossification of the skeletal system (Gale 1978).

Biomarkers of Chromium Exposure/Effect. Chromium accumulator organs in mammals are the brain, for hexavalent chromium, and the kidney, for trivalent chromium. Tissue levels in excess of $4 \mathrm{mg}$ total $\mathrm{Cr} / \mathrm{kg}$ dry weight is indicative of chromium contamination (Eisler 1985). However, there is no correlation between the tissue concentration and dose or the extent of tissue damage for either valence state of chromium (Hatherhill 1986).

Exposure to chromium, even at low levels, induces a relatively specific necrosis in the proximal convoluted tubule of the kidney nephrons. This lesion could possibly be used as an indicator of sublethal, but injurious, exposure to the chromium. Mercury poisoning also induces necrosis of the proximal convoluted tubule, but differs in its localization (Goyer 1986).

It has been suggested that renal clearance of chromium can be used as an index of current exposure and body burden of chromium (Franchini et al. 1978; Borghetti et al. 1977).

Chromium Toxicokinetics: Metabolism and Distribution. In general, chromium compounds are poorly absorbed from the gastrointestinal tract. Less than $1 \%$ of an oral dose of trivalent chromium is absorbed from the digestive tract of rats; absorption of hexavalent chromium ranges from 1\% to 6\% (Langard and Norseth 1986; Visek et al. 1953; Underwood 1977; Ogawa 1976). Although hexavalent chrornium can readily pass through cell membranes, the acid $\mathrm{pH}$ of the stomach reduces much of the ingested hexavalent chromium to the trivalent form. Trivalent chromium cannot pass through membranes, as absorption from the stomach is negligible (MacKensie et al. 1959; Donaldson and Barreras 1966). Trivalent chromium is not converted to hexavalent chromium in the body. In the alkaline $\mathrm{pH}$ of the duodenum, the chromium salts form insoluble polynucleate bridge hydroxo-aquo complexes that are excreted in feces. However, some of the complexes remain in solution and are absorbed into the blood (Hopkins and Schwarz 1964; Nelson et al. 1973).

About $0.1 \%$ to $1.2 \%$ of ingested trivalent chromium and $0.2 \%$ to $4 \%$ of hexavalent forms are excreted in the urine within $24 \mathrm{~h}$. The bulk $(84.7 \%$ to $96.7 \%)$ of the chromium is eliminated in the feces (Donaldson and Barreras 1966). Of the absorbed chromium, about $80 \%$ is excreted in the urine (Hopkins 1965; Mancuso and Hueper 1951). The estimated half-life of hexavalent chromium is 22 days; the half-life of whole-body elimination of trivalent chromium is 92 days (Yamaguchi et al. 1983).

At low doses ( 1 and $10 \mu \mathrm{g} / \mathrm{kg}$ body weight), hexavalent chromium accumulates in the bone marrow, spleen, testis, epididymis, and heart. At higher dose levels (60 and $250 \mu \mathrm{g} / \mathrm{kg}$ ), the major accumulation sites are the liver, spleen, and bone marrow (Langard and Norseth 1986). 
Trivalent chromium remains in the lungs after intratracheal application, whereas the soluble hexavalent compounds are absorbed into the bloodstream. About $80 \%$ of inhaled chromium is excreted in the urine (Shacklette et al. 1978).

Uptake of chromium through the intact skin is very low. Hexavalent chromium is converted to trivalent chromium on the skin.

No significant transfer of chromium from the mother to the fetus occurs unless the chromium is in a natural complex (Shacklette et al. 1978; Steven et al. 1976; Langard and Norseth 1979).

\section{Birds}

Adverse effects of chromium to sensitive species have been documented in wildlife at 5.1 and $10 \mathrm{mg}$ of hexavalent chromium and trivalent chromium, respectively, per $\mathrm{kg}$ of diet (ppm). Aerosol concentrations in excess of $50 \mu \mathrm{g}$ hexavalent chromium $/ \mathrm{m}^{3}$ are potentially harmful to human health. In the absence of supporting data, this value is recommend for protection of sensitive species of wildlife, especially migratory waterfowl (Eisler 1985).

Dietary exposure to 10 or $50 \mathrm{ppm}$ trivalent chromium for 5 months did not affect survival, reproduction, or blood chemistry of adult black ducks. However, duckling growth patterns were altered and survival rates were reduced by these diets (Heinz and Haseltine 1981). No change in frightresponse behaviors was observed in either the adults or ducklings (Heinz and Haseltine 1981). However, exposure to $100 \mathrm{ppm}$ hexavalent chromium in the diet for 3 months was fatal to ducks (Steven et al. 1976). Administration of $11.2 \mathrm{ppm}$ in drinking water was not lethal over a 4-year period (Steven et al. 1976). Chickens appear to be more resistant to hexavalent chromium as exposure to $100 \mathrm{ppm}$ in the diet did not cause any adverse effects (Rosomer et al. 1961).

Severe deformities were observed in chicken embryos following injection of $0.2 \mathrm{mg} / \mathrm{kg}$ (Giliani and Marano 1979). Embryolethality (LD50) was observed when $1.7 \mathrm{mg} / \mathrm{kg}$ of hexavalent chromium or $22.9 \mathrm{mg} / \mathrm{kg}$ of trivalent chromium was injected into the eggs (Ridgeway and Karnofsky 1952). Deformities were produced by the hexavalent chromium, but no teratogenic effects were seen with injection of trivalent chromium (Ridgeway and Karnofsky 1952). No information is available on transfer and effects of chromium in eggs from adult exposure.

\subsection{Bioconcentration Factors and Trophic Transfer Coefficients}

The relationship between concentrations of chromium in a given environment and the biological effects on the organisms living there is poorly defined. Accumulation of chromium in organisms and tissues is highly dependent on the chemical form of the compound, route of entry, and exposure concentration (Yamaguchi et al. 1983). The highest concentrations of chromium are found at the lowest trophic levels. No biomagnification of chromium has been observed in food chains. 


\subsubsection{Chromium Transfer in Aquatic Food Chains}

Concentration ratios of chromium in freshwater systems were reported by Vaughan et al. (1975) to be 250 for aquatic plants, 20 for invertebrates, and 40 for fish. Green algae accumulated hexavalent chromium at a rate of about 1000 times that of the water. In general, chromium is accumulated in large amounts by living or dead plant tissue. Mangi et al. (1979) suggest that accumulation by plant tissue occurs at a rate that linearly approximates concentration on a logarithmic basis. According to EPA guidelines, sediments are considered polluted when chromium concentrations are greater than or equal to $25 \mathrm{mg} / \mathrm{kg}$. In annelid worms (Tubifex sp.), the concentration factor for trivalent chromium from sediments was 0.0057 (Neff et al. 1978).

\subsubsection{Chromium Transfer through Terrestrial Food Chains}

Generally, most of the chromium in soil and sediment is unavailable for uptake by biota. Bioavailability of chromium waste in soils is modified by soil $\mathrm{pH}$ and the presence of organic complexing substances (James and Bartlett 1983a, 1983b). Because organic material in soil will reduce any soluble hexavalent chromium to insoluble $\mathrm{Cr}_{2} \mathrm{O}_{3}$, chromium in soil is found mainly in the trivalent form (Towill et al. 1978). A free trivalent ion is rapidly adsorbed or hydrolyzed and precipitated in soils lacking complexing substances. Organically complexed trivalent chromium remains soluble for at least 1 year.

The concentration ratio for plants grown on soils containing endogenous chromium was $\mathbf{0 . 0 0 2}$. A concentration ratio of 0.06 was observed in plants grown in amended soil. Distribution of the absorbed chromium was largely restricted to the lower stems (Cataldo and Wildung 1978).

Beetles and crickets collected near cooling towers of uranium enrichment facilities had 9 to $37 \mathrm{ppm}$ chromium in gut contents. Assimilation rates were not measured. Cotton rats trapped in a fescue field adjacent to a cooling tower contained up to 10 times more chromium in fur, pelt, and bone than controls. No accumulation was seen in viscera and other internal organs. Licking of the coat by rats appeared to be a primary route of chromium uptake (Langard and Nordhagen 1980). Radiochromium uptake studies indicate low assimilation $(0.8 \%)$ and rapid initial loss of hexavalent chromium ( $99 \%$ in 1 day) in rats. Mice fed $0.1 \mathrm{ppm}$ hexavalent chromium in their food and water during a lifetime had $0.1 \mathrm{mg}$ chromium $/ \mathrm{kg}$ fresh weight in their liver and $0.7 \mathrm{mg} / \mathrm{kg}$ in the heart. A diet containing $5.1 \mathrm{ppm}$ hexavalent chromium for a similar period resulted in liver and heart levels of $0.5 \mathrm{mg} / \mathrm{kg}$ and $1.8 \mathrm{mg} / \mathrm{kg}$, respectively (Schroeder et al. 1964).

Few concentration factors are reported. Chromium levels considered to be high enough to consider the organism contaminated are listed in Table 8.4 . 
Table 8.4. Chromium Concentrations in Organisms from Contaminated Terrestrial Systems (Eisler 1985)

\section{Organism}

\section{Plants}

Big Sagebrush

Fescue (grass)

Rye

Corn (kernels)

Insects

Termites '

Annelids

Earthworms

Mammals

Pronghom (hair)

Coyote (hair)

Elk (hair)

Cotton Rat (whole body)

Westem Jumping Mouse (hair)

Birds

Ducks (liver)

(eggs)

Gull

Osprey (liver)
Chromium

Content (ppm)

77-400 dw(a)

15-342 dw

2.2-3.3 dw

$0.02 \mathrm{fw}(\mathrm{b})$

$1500 \mathrm{dw}$

$1-13 d w$

0.3-640 dw

$0.7-12 \mathrm{dw}$

1.9-570 dw

$0.12 \mathrm{fw},(0.4) \mathrm{dw}$

23-45 dw

$0.02 \mathrm{fw}$

$0.06 \mathrm{fw}$

$<1 \mathrm{dw}$

$<$ f $w$

(a) dw dry weight.

(b) fw fresh weight. 


\subsection{Technetium}

\subsection{Technetium Toxicity}

Although technetium has a long half-life and is distributed more readily in the environment than most other radionuclides with long half-lives, technetium- 99 as a beta-emitter is much less toxic than the alpha-emitting actinides. The toxicity of technetium in animals is low and appears to be related to the radioactive properties of the radionuclide rather than its chemical properties. However, a chemical toxicity has been associated with reduced fertility. Technetium is very toxic to plants. Its chemical properties affect the distribution, and biological half-life in plants, and may influence the retention of plutonium in target tissues (Roucoux and Colle 1986).

\subsubsection{Toxicity in Aquatic Biota}

The toxicity of technetium in aquatic biota is discussed below.

\section{Aquatic Plants}

Technetium exposure to $7.56 \times 10-4 \mathrm{M}(123 \mathrm{mg} / \mathrm{L}$ ) (as pertechnetate) induced long lag periods in growth and bleaching of cells in blue-green algae (Gearing et al. 1971).

\section{Invertebrates}

No information is available regarding chemical toxicity. See Section 2.1 for radiation impacts.

\section{Fish}

No information is available regarding chemical toxicity. See Section 2.1 for radiation impacts.

\subsubsection{Toxicity in Terrestrial Biota}

The toxicity of technetium to terrestrial biota is presented in the following paragraphs.

\section{Plants}

Growth anomalies only occur in plants germinated in the presence of technetium, indicating that the toxicity of this radionuclide is probably associated with early stages of plant growth such as embryonic cell division. Adverse effects on germinating wheat seedlings were first observed at shoottissue concentrations of 0.68 to $2.8 \mu \mathrm{Ci} / \mathrm{g}$ (a specific activity of $17 \mathrm{mCi} / \mathrm{g}$ corresponds to technetium levels in tissue of 40 to $165 \mathrm{ppm}$ ). The threshold dose rate that induced depression of shoot-tissue yield occurred at $2 \mathrm{rad} / \mathrm{d}$. This low-dose rate suggests technetium toxicity is chemical rather than 
radiological. Technetium-treated plants display similar symptomology to plants suffering from 2,4-D poisoning (Landa et al. 1977). In lettuce, the chemical toxicity threshold (growth reduction) was observed at concentrations of $0.2 \mathrm{ng} / \mathrm{g}$ dry weight of soil (Masson et al. 1989). The lethal concentration for Swiss chard was $0.05 \mu \mathrm{g}$ technetium/g dry soil. Even at low concentrations of $0.1 \mu \mathrm{g}$ technetium/g dry soil, technetium has been shown to inhibit plant growth and development in soybeans (Cataldo et al. 1978). Toxic effects were largely observed in buds and young leaves rather than in mature tissues (Finch 1983). It appears that incorporation of technetium results in technetium-cysteine, which is unable to form disulfide-like bridges. Formation of technetiumcysteine leads to nonfunctional proteins that accumulate and to increased production proteins (which end up defective) that, in turn, lead to metabolic dysfunction, especially in young tissue where protein synthesis is critical (Cataldo et al. 1989). Cellular effects of technetium have also been attributed to alteration of membrane permeability (Neel and Onasch 1989).

See Section 2.1 for additional information on radiation toxicity.

\section{Invertebrates}

No information is available regarding chemical toxicity. See Section 2.1 for radiation impacts.

\section{Amphibians/Reptiles}

No information is available regarding chemical toxicity. See Section 2.1 for radiation impacts.

\section{Mammals}

Because stable isotopes of $\mathrm{t}$ chemical toxicity of technetium in. toxicity is probably between manganese and rhenium. The toxicity of common manganese compounds varies from 90 to $934 \mathrm{mg} / \mathrm{kg}$ (Bowen 1979; NIOSH 1987). Rhenium toxicity is low. Intraperitoneal injection of rhenium trichloride results in an LD50 of $280 \mathrm{mg} / \mathrm{kg}$ (Lewis 1992). The metastable isomer, technetium- $99 \mathrm{~m}$, is used as a tracer and diagnostic tool in biology and medicine because of its low beta-particle energy, yet high specific activity, and poor absorption by mammals (Durbin 1960; Harper et al. 1964). Administration of very high concentrations of technetium $(10 \mu \mathrm{g} / \mathrm{g})$ in food is required to produce deleterious effects to thyroid function, fertility, and postnatal development (Van Bruwaene et al. 1986; Gerber et al. 1989). Because the radiation dose to the conceptus was only about 10 to $20 \mathrm{mGy}$, the fertility and fetal development impacts are likely caused by the chemical rather than radiation toxicity of technetium.

Biomarkers of Technetium Exposure/Effect. Technetium tends to concentrate in the thyroid and parathyroid (McGill et al. 1971). However, no relationship between tissue activity and exposure or 
dose-response information is available. Other tissues with pronounced technetium concentration are the bone and skin. Hair also accumulates technetium and may be useful as a bioindicator of technetium exposure (Gerber et al. 1989).

Technetium Toxicokinetics: Metabolism and Distribution. In mammals, absorption of inorganic pertechnetate from the gastrointestinal tract is about $90 \%$. However, biological half-life in humans is 2 days. Nearly all technetium is excreted within a week (Beasley et al. 1966). However, when technetium has been incorporated in plant tissue, the absorption rate is greatly reduced. About $75 \%$ of the ingested dose of technetium-95m incorporated in soybean tissue was excreted in the feces in 2 days in rats (Sullivan et al. 1979). Less than 10\% was excreted in the urine. In guinea pigs, about $80 \%$ of the technetium-95m ingested as soybean-incorporated material was excreted in the feces and $10 \%$ in the urine within 2 days (Sullivan et al. 1979). Polygastric animals appeared to absorb less technetium than monogastric animals (Gerber et al. 1989). This reduced absorption may be due to the reduction of $\mathrm{TcO}_{4}$ - in the rumen of polygastric animals that interferes with its reabsorption from the intestine (Jones 1989).

\section{Birds}

Although technetium is concentrated in avian oocytes (Roche et al. 1957; Thonas et al. 1984), no impacts to developing embryos have been noted.

No information is available regarding chemical toxicity. See Section 2.1 for radiation impacts.

\subsection{Bioconcentration Factors and Trophic Transfer Coefficients}

Technetium is very mobile, particularly in terrestrial ecosystems. It is poorly retained by aerated soil and accumulates in plants. Although assimilation of ingested technetium compounds can be high, retention of the radionuclide is low in animals. Transfer of technetium incorporated in plant tissue to animals and its retention in their tissues are even lower than for unincorporated technetium, indicating a low potential for food chain magnification.

\subsubsection{Technetium Transfer in Aquatic Food Chains}

Under anaerobic sediment conditions, technetium is reduced to Tc (IV), which is not absorbed by roots and, thus, macrophytes are unable to concentrate technetium in their tissues (Sheppard and Evendon 1991). The Commission of the European Communities (1979) suggests a technetium concentration factor for freshwater fish of $30 \mathrm{~L} / \mathrm{kg}$. This value is then multiplied by the concentration of technetium in the water (Zeevaert et al. 1989). In the absence of site-specific data, recommended default values for the water-based bioconcentration factor for technetium in the flesh of freshwater fish are 15 (NRCC 1983), 30 (CSA 1987), and 15 (Poston and Klopfer 1986; Myers et al. 1989). 
No information was available on uptake of technetium in other components of the aquatic food chain.

\subsubsection{Technetium Transfer through Terrestrial Food Chains}

Plants readily concentrate technetium in their tissues and play an important role in technetium cycling in the environment. Plants are able to effectively accumulate technetium at soil levels as low as $0.01 \mu \mathrm{g} / \mathrm{g}$. Hydroponically grown plants concentrate technetium in their tissues at culture levels as low as $0.02 \mathrm{pg} / \mathrm{mL}$ (Cataldo et al. 1989). In general, between $47 \%$ and $74 \%$ of the technetium applied to soil in water is assimilated by plants. Dicotyledon species appear to have a much higher root/shoot concentration ratio than is found in monocots. Cataldo and Wildung (1983) reported a $25 \%$ translocation of absorbed technetium from the root to the shoots, whereas about $5 \%$ to $7 \%$ of the technetium was found in root tissue and $42 \%$ to $67 \%$ appeared in the above-ground tissue of wheat seedlings (Landa et al. 1977). Concentration factors for technetium from the upper $15 \mathrm{~cm}$ of soil at field sites have been reported to range from 3 to 370 (Garland et al. 1983) and from 2 to 200 (Hoffman et al. 1980). Laboratory studies have produced concentration factors of 10 to 1200 (Landa et al. 1977; Wildung et al. 1977; Mousney and Myttenaere 1981). For native plants at the Hanford Site, Rouston and Cataldo (1977) have suggested a concentration factor of 76 to 390 for tumbleweed and 54 to $\mathbf{4 2 1}$ for cheat grass from five Hanford project soils. Swiss chard grown on different soil types had concentration factors of 11 to 2600 . The variation in uptake appeared to be related to soil sorption of technetium in peat. Technetium uptake by the chard was four orders of magnitude higher in sand than for plants grown in peat (Sheppard et al. 1983). The final transfer coefficient was reached within 2 days of growing in contaminated soil and remained constant for the life of the plant (Masson et al. 1989). Van Loon et al. (1989) have described a general soil-to-plant transfer function for technetium.

Note that although techne:ium mobility is almost unretarded in aerated surface soils (and, therefore, readily accumulated by plants), technetium in unaerated soils is much less available (Sheppard et al. 1990; Garten 1987). This finding suggests that root depth is an important consideration in estimating plant uptake. Indeed, Sheppard and Evenden (1985) showed that technetium in the unaerated subsoil was not available to a terrestrial cereal.

Most soil parameters do not affect technetium uptake in plants. However, fertilized soil reduces technetium uptake. Concentration factors $(\mu \mathrm{Ci} / \mathrm{g}$ tissue $/ \mu \mathrm{Ci} / \mathrm{b}$ soil) were 700 for plants grown in fertilized soil and 950 for plants grown in unfertilized soil (Landa et al. 1977). Nutrients effective in reducing uptake included manganese, sulfate, phosphate, and molybdenate (Cataldo et al. 1989).

Plants grown on soils containing technetium concentrations less than $0.1 \mu \mathrm{g} / \mathrm{g}$ were more effective at technetium uptake and removed up to $90 \%$ of the radionuclide from the soil. The presence of actinides has been reported to enhance technetium uptake in plants in some soil types (Masson et al. 1989). Technetium uptake in leaves of radish plants grown in calcareous soils was increased 4 times in the presence of uranium and 4.5 times in plutonium-amended soils. Plutonium also appeared to increase technetium uptake 1.5 times in the leaves and 3 times in roots of plants grown in acid soils. 
The presence of americium in organic soils resulted in a sixfold increase in leaf uptake of technetium (Roucoux and Colle 1986; Masson et al. 1989). However, because no soil/plant concentrations or statistical information is presented, the validity of the reported technetium actinide relationship is unclear.

Incorporation of technetium in plant tissue alters the absorption and retention of the radionuclide in animal tissues. Whole body retention of incorporated technetium was less than $1 \%$ in rats and $0.5 \%$ in guinea pigs after 6 days (Sullivan et al. 1979). Although as much as $8.4 \%$ of ionic technetium was transferred to quail eggs, only $2 \%$ was transferred when the radionuclide was ingested in plant material (Thomas et al. 1984). Of the technetium deposited in the egg, 80\% appeared in the yolk and $20 \%$ in the albumin. 


\subsection{Tritium}

\subsection{Tritium Toxicity}

Tritium released from nuclear facilities enters the environment mainly as tritiated water and is, therefore, distributed rapidly throughout the biosphere. Tritium decays by beta particle emission with a maximum energy that is about one-hundredth of the energy of most beta emitters. Because beta particles of such low energy can only penetrate about $0.004 \mathrm{~mm}$ of tissue, an external radiation dose from tritium is not considered hazardous (Blaylock 1973). The short biological half-life of tritium also decreases its hazard relative to other radionuclides. The biological effects induced by tritium exposure do not differ in any qualitative way from those induced by external $X$ - or gammaradiation. Reference should be made to Section 2.1 for a description of the ionizing radiation toxicity.

\subsubsection{Toxicity in Aquatic Biota}

Exposure of fertilized eggs to beta radiation from tritiated water altered lifetime reproduction in mature medaka (Oryzias latipes), a small teleost fish (Taguchi and Etoh 1986). Reduced oviposition frequency and number of eggs laid per fish were observed in pairs composed of female fish exposed for 10 days during embryonic development and unirradiated males. However, those eggs produced were fertilized and hatched normally. When irradiated males were mated with unirradiated females, the number of fertilized eggs per fish and the hatchability of the fertilized eggs were reduced significantly. Both the reduced fecundity in females and fertility in males were observed at the lowest dose tested, $0.05 \mathrm{mCi} / \mathrm{mL}$ (total accumulated dose of $85 \mathrm{rad}$ ). Higher doses produced completely infertile fish. The response was dose-dependent. Fifty percent loss of female reproductive capacity occurred at an accumulated dose of tritium beta emissions of $400 \mathrm{rad}$.

See Section 2.1 for effects of ionizing radiation on aquatic biota.

\subsubsection{Toxicity in Terrestrial Biota}

The toxic effects of tritium on terrestrial biota are summarized below.

\section{Plants}

See Section 2.1 for effects of ionizing radiation on terrestrial biota.

\section{Invertebrates}

See Section 2.1 for effects of ionizing radiation on terrestrial biota. 


\section{Amphibians/Reptiles}

See Section 2.1 for effects of ionizing radiation on terrestrial biota.

Birds

See Section 2.1 for effects of ionizing radiation on terrestrial biota.

\section{Mammals}

Because tritium, as tritiated water, is readily absorbed into the bloodstream from all routes of exposure and is distributed throughout the body, any radiation effects are comparable to whole-body irradiation (Osborne 1972; Stannard 1973). Entry of tritium into the body in organic form may lead to a concentration of the radionuclide within vital structures such as DNA. Once incorporated into DNA, tritium remains there until the cell's death. The genetic consequences of this incorporation, particularly in the most radiation-sensitive organs like ovary or testes, are of concern. When tritium is administered as tritiated water, less than !\% of the ingested tritium is incorporated into the organic compartment. However, administration of tritiated food results in a $4 \%$ to $11 \%$ incorporation of tritium in this compartment (Kirchmann et al. 1977). About 75\% of the total hydrogen in the mammalian body is in the form of water, $14 \%$ is in proteins, and less than $0.5 \%$ is in nucleic acids (DNA and RNA) (Commerford 1984).

See Section 2.1 for effects of ionizing radiation on terrestrial biota.

Biomarkers of Tritium Exposure/Effect. Radioactivity of the exchangeable water component of the body can provide information on current exposure.

Tritium Toxicokenetic: Metabolism and Distribution. Only $0.004 \%$ of inhaled tritium dissolves in the blood and is transported throughout the body (Peterman 1982; Peterman et al. 1985). Uptake of tritiated water vapor is about equal along both the inhalation and dermal absorption route (Pinson and Langham 1957; Osbum 1978).

Distribution of organically bound tritium in rats, calves, and rabbits appears to be related to the metabolic activity of the individual tissues. The liver, kidney, and small intestine have much higher concentrations of tritium than the muscle and brain (Kirchmann et al. 1973; Pietrzak-Flis et al. 1978; Takeda arid Iwakura 1992).

\subsection{Bioconcentration Factors and Trophic Transfer Coefficients}

As one would expect of water molecules, tritiated water is readily taken up by biota and incorporated into tissues. Plants appear to incorporate tritium more efficiently by photosynthetic 
processes (Choi and Aronoff 1966; Kanazawa et al. 1982). Consumption of plant tissues by animals distributes the tritium into food webs. Retention of tritium in the food chain depends on the rate of catabolism at the trophic levels. Lipids are not completely catabolized, leading to retention of tritium, whereas carbohydrates are more completely catabolized, leading to loss of tritium from the food chain. The metabolic tumover rate of the carbon-associated tritium compounds then determines the concentration of tritium in the organism. Overall, neither plants nor animals concentrate tritium in their tissues, and tritium enrichment in food chains has not been observed.

\subsubsection{Tritium Transfer in Aquatic Food Chains}

Tritiated water can exchange with mobile chemical sites in fish flesh. In addition, tritium can be metabolically incorporated on less exchangeable sites in the fish from catabolic processes using contaminated organic matter that has moved up the food chain. In a study of tritium uptake by largemouth bass in a stream near the center of the Savannah River Site, samples of fish flesh were freezedried, and the tritium content of the freeze-dried water was determined. Because tritiated water exchanges rapidly with fish, this measure reflects the concentration to which the fish had been exposed the previous day. The freeze-dried flesh was then combusted, and the water of combustion was analyzed for tritium content to provide information on the amount of organically bound tritium in the fish. Tritium activity of the stream water and vegetation was compared to levels of tritium in the fish. The results showed that the tritium content of the fish flesh was about equal to the tritium in the water of the previous year (Eaton and Murphy 1992).

\subsubsection{Tritium Transfer through Terrestrial Food Chains}

The biological half-life of tritium in plants can be defined by three components. The first component is rapidly excreted $(0.3$ to $2.0 \mathrm{~h})$ and represents over $90 \%$ of the total incorporated tritium. Organically bound tritium turns over more slowly and has a half-life of about 17 to $30 \mathrm{~h}$. The third component is from tritium in soil water and has a half-life of 80 to $270 \mathrm{~h}$ (Anspaugh et al. 1973; Koranda and Martin 1973; Belot et al. 1979; Guenot and Belot 1984). Plant concentration ratios are less than 1 for plants exposed to tritiated water (Diabate et al. 1990).

Significantly higher (10- to 60-fold) incorporation of tritium into mammalian tissues is seen after exposure to triated vegetation than to tritiated water (Kirchmann et al. 1977; Takeda and Iwakura 1992). Different incorporation rates of tritium into rat tissues were seen for different plant species. The difference appeared to be related to the chemical composition of the plants, with a higher protein content of the plant resulting in higher tritium incorporation into the rat tissues. High tritium incorporation into fat tissue of rats was also observed in rats fed plants with high fat content (e.g., soybean) (Takeda and Iwakura 1992). Concentration ratios of tritium in all tissuss in rats were less than 1.0 (range 0.24 to 0.60 ) for rats fed tritiated rice. Higher concentration ratios were seen in rats fed tritiated soybean ( 0.32 to 1.10 ). Only the liver and lung of rats fed this higher fat food had concentration ratios greater than 1.0. Specific activity rations between concentrations in milk of ruminants and d́rinking water were about 0.83 for milk water, 0.48 for lactose, 0.3 for milk fat, and 0.22 for 
casein (Van Den Hoek et al. 1983). Ratios between milk and feed in ruminants were 0.10 for milk water, 0.84 for milk fat, 0.49 for casein, and 0.05 for lactose (Van Den Hoek et al. 1983). About $0.7 \%$ of the total ingested activity of tritiated water was incorporated into the main organs of pigs. When tritium was ingested as tritiated milk powder, $4.8 \%$ of the total activity ingested was incorporated into the tissues. Ingestion of tritiated potatoes resulted in an incorporation of $10.98 \%$ of the total activity into the major organs of the pig (Kirchmann et al. 1977). As shown in Table 10.1, no concentration of tritium is seen in animals exposed to tritiated water or feed. The one exception was the kangaroo rat, which has a unique water metabolism allowing it to maintain a positive water balance eating dry grain. The biological half-lives of tritium in mammals and birds are listed in Table 10.2.

Table 10.1. Specific Activity Ratios in Mammals after Continuous Tritium Intake (Diabate and Strack 1990)

\begin{tabular}{|c|c|c|c|}
\hline Species & Exposure & $\begin{array}{c}\text { Specific } \\
\text { Activity Ratio }\end{array}$ & Reference \\
\hline Rats & Triated water & $0.2-0.47$ & $\begin{array}{l}\text { Thompson and Ballou } 1956 \\
\text { Laskey } 1973\end{array}$ \\
\hline Rats & Tritiated meat & $0.22-0.37$ & Pietrzak-Flis et al. 1982 \\
\hline Mice (liver and testes) & Tritiated water & $0.25-0.4$ & Hatch and Mazrimas 1972 \\
\hline Kangaroo Rats & Tritiated environment & $1.2-1.6$ & Martin and Koranda 1972 \\
\hline Rabbits & Tritiated water and feed & $0.95-1.0$ & Moghissi et al. 1987 \\
\hline
\end{tabular}

Table 10.2. Biological Half-Lives of Tritium in Body Water of Mammals and Birds (Van Den Hoek et al. 1983)

\begin{tabular}{|c|c|c|}
\hline \multirow[b]{2}{*}{ Species } & \multicolumn{2}{|c|}{ Biological Half-Life (days) } \\
\hline & First Compartment & Second Compartment \\
\hline Mouse & $1.1-1.6$ & 23 \\
\hline Kangaroo Rat & 13.3 & 114 \\
\hline Chicken & 4.6 & \\
\hline Pig & $3.8-4.3$ & \\
\hline Cow (lactating) & $3.1-4.0$ & 33 \\
\hline Cow (non-lactating) & 4.0 & 40 \\
\hline
\end{tabular}




\subsection{Europium}

\subsection{Europium Toxicity}

Europium is a rare-earth element; i.e., an element in the lanthanide series. Because the lanthanide elements possess similar physical and chemical properties, their toxicities are also similar. Where data for europium are lacking, available inform tion on similar rare-earth elements is reported to provide information on relative toxicity.

\subsubsection{Europium Toxicity in Aquatic Biota}

No information on the toxicity of europium to aquatic biota is available. For radioactive isotopes of europium, see Section 2.1 for a review of radiation toxicity.

\subsubsection{Europium Toxicity in Terrestrial Biota}

Europium toxicity is terrestrial biota is recorded below.

\section{Plants}

No information is available on the toxicity of europium to terrestrial plants.

\section{Invertebrates}

No information is available on the toxicity of europium to terrestrial invertebrates.

\section{Mammals}

Europium, along with the other lanthanide elements, is considered practically nontoxic when administered orally. In laboratory rats, the oral LD50 for nitrate compounds of the lanthanides is $5000 \mathrm{mg} / \mathrm{kg}$. The oral LD50 for lanthanide chlorides in rats and mice is $5000 \mathrm{mg} / \mathrm{kg}$ (RhonePoulenc 1986, 1987). Oxides of rare-earth metals have LD50 values greater than $1000 \mathrm{mg} / \mathrm{kg}$ and may be as low as $10,000 \mathrm{mg} / \mathrm{kg}$ (Lewis 1992). No growth inhibition or histopathological damage was observed in mice and rats fed europium chloride at $1 \%$ of their diet for 3 months and europium at $0.05 \%$ of the diet caused no adverse effects through 3 generations of mice (Hutcheson et al. 1975a).

Europium is probably moderately toxic follow'ing parenteral administration of its soluble salts. Animal studies show that rare-earth oxides (cerium and neodymium) are less toxic than yttrium by inhalation. Intratracheal installation of $50 \mathrm{mg}$ yttrium oxide produced granulomatous nodules and emphysematous changes in rats after 8 months (Mogliveskaya and Raikhlin 1963). Assuming 
europium is less toxic than yttrium, no adverse effects from inhalation of the lanthanide element are anticipated in humans after a lifetime exposure to $1 \mathrm{mg} / \mathrm{m}^{3}$ (Stokinger 1981).

Rare-earth salts may irritate or damage eyes and abraded skin (Haley 1977).

Toxicokinetics: Metabolism and Distribution. Gastrointestinal absorption of the compounds of rare-earth metals is poor. In mammals, absorption of lanthanide salts is less than $0.05 \%$. This low level of absorption has been recorded in all species studied so far. Species tested include rats and mice (Cochran et al. 1950; Haley 1965; Hutcheson et al. 1975b; Luckey et al. 1975), goats (Ekman and Aberg 1961), and cows (Gamer et al. 1960). Retention in mammals occurs mostly in the skeleton and less in soft tissues, except the liver. Low levels of absorbed lanthanides are distributed rapidly into the liver and kidneys followed by a gradual uptake and retention in the bones. Depositions of lanthanides are generally about $50 \%$ in liver and $50 \%$ in bone. The skeleton retains about $67 \%$ of the initial deposition after eight months (Hart et al. 1955). Intermediate concentrations of lanthanides separate out as colloidal hydroxides of phosphates and are removed by macrophages. They are then transported to the lymph nodes, bone marrow and liver. Subsequently, they are excreted into the digestive tract through the enteropathic circulation. Urinary excretion is also documented (Wald and Mode 1989).

Biomarkers of Radiation Exposure. No biomarkers of exposure were found in the literature. Liver is the target organ in lanthanide intoxication, and fatty liver degeneration and mitochondrial damage are observed at high concentrations (Snyder et al. 1959). However, the pathology is not unique to europium toxicity.

Birds

Teratogenic effects have been observed in chicken embryos after injection of europium chloride into the yolk sac of 8-day-old embryos. An injection of $20 \mathrm{mg}$ europium as europium chloride caused leg deformities, joint damage, inhibition of feather formation, and edema (Zanni 1965). Female chicks were more susceptible to the teratogenic challenge than males.

\subsection{Bioconcentration Factors and Trophic Transfer Coefficients}

Little information is available on the accumulation and transfer of europium in aquatic and terrestrial food chains. Because lanthanide oxides are relatively insoluble and lack bi logical function, europium uptake and food chain transport are not expected.

\subsubsection{Radionuclide Transfer in Aquatic Systems}

No information is available on the bioaccumulation and trophic transfer of europium in freshwater systems. 


\subsubsection{Radionuclide Transfer in Terrestrial Systems}

In general, plants do not absorb the lanthanides from the soil because of discrimination against their absorption by the roots. This effectively blocks the dietary transfer of lanthanides from soil to animals (Wald and Mode 1990). Shibuya and Nakai (1963) reported an accumulation of $0.21 \mathrm{ppm}$ europium in terrestrial plants grown in areas where igneous rock is prevalent. Assuming a soil content of 1 to $2 \mathrm{ppm}$ for soils of igneous rock origin (Bowen 1966), a bioaccumulation factor of about 0.014 may be estimated. Walnut species (Carya), which excrete complexing agents and have large concentrations of natural ligand in their rhizosphere, accumulate much higher levels of europium (Robinson et al. 1958). Calculated concentration factors for these species may range from 16 to 80 .

No information is available for trophic transfer to higher organisms. 


\subsection{Nitrate}

\subsection{Nitrate Toxicity}

Nitrate toxicity to both aquatic and terrestrial biota is low. Toxic levels have been shown to accumulate in some plant species under certain conditions. However, both acute and chronic poisonings are rare.

\subsubsection{Nitrate Toxicity to Aquatic Biota}

Nitrate toxicity to aquatic invertebrates is low (Hohreiter 1980). The LC50 for planaria (Polycelia nigra) is $1000 \mathrm{mg}$ nitrate/L (Jones 1940). The acute 96-h LC50 for Daphnia magna is $665 \mathrm{mg} / \mathrm{L}$ (Dowden and Bennett 1965). Anderson (1944) reported immobilization of Daphnia magna after exposure to $5000 \mathrm{mg} / \mathrm{L}$ nitrate for $48 \mathrm{~h}$. Reported $24-\mathrm{h}$ LC50 for snails are $6000 \mathrm{mg} / \mathrm{L}$ for Blomphalaria alexandrina, and 3100 for Pulinus truncatus (Gohar and El-Gindy 1961). The 96-h LC50 for Lymnes species is 3251 (Dowden and Bennett 1965).

Nitrate levels in water that are harmful to freshwater fish are listed in Table 12.1.

Table 12.1 LC50 Values for Nitrate in Freshwater Fish

\begin{tabular}{|c|c|c|c|}
\hline Species & Test Duration & $\begin{array}{l}\mathrm{LC50} \\
\left(\mathrm{m} / \mathrm{L}, \mathrm{NO}_{3}-\mathrm{N}^{(\mathrm{n})}\right)\end{array}$ & Reference \\
\hline \multirow[t]{2}{*}{ Chinook Salmon (Oncorynchus tshawytscha) } & $96 \mathrm{~h}$ & 1,310 & Westin 1974 \\
\hline & $7 d$ & 1,080 & Westin 1974 \\
\hline Rainbow Trout (Oncorhynchus mykiss) & $96 \mathrm{~h}$ & 1,360 & Westin 1974 \\
\hline (fingerlings) & $7 d$ & 1,060 & Westin 1974 \\
\hline Bluegills (Lepomis macrochirus) & $\begin{array}{l}96 \mathrm{~h} \\
96 \mathrm{~h}\end{array}$ & $\begin{array}{c}2,000\left(\mathrm{NaNO}_{3}\right) \\
420\left(\mathrm{KNO}_{3}\right)\end{array}$ & $\begin{array}{l}\text { Trama } 1954 \\
\text { Trama } 1954\end{array}$ \\
\hline large & $96 \mathrm{~h}$ & 9,000 & Cairns and Scheier 1959 \\
\hline medium & $96 \mathrm{~h}$ & 10,000 & Caims and Scheier 1959 \\
\hline small & $96 \mathrm{~h}$ & 9,400 & Caims and Scheier 1959 \\
\hline Mosquito Fish (Gambusia affinis) & $96 \mathrm{~h}$ & 6,650 & Wallen et al. 1957 \\
\hline Goldfish (Carassius auratus) & $14 \mathrm{~h}$ & 1,282 & Powers 1971 \\
\hline Warm water fish & life & 90 & Knepp and Arkin 1973 \\
\hline
\end{tabular}

(a) $1.0 \% \mathrm{NO}_{3}-\mathrm{N}=4.4 \% \mathrm{NO}_{3}$ 


\subsubsection{Nitrate Toxicity in Mammals}

The nitrate toxicity in terrestrial biota is summarized below.

\section{Mammals}

Nitrate is of very low toxicity to animals and is rapidly excreted in the urine. It becomes a hazard only at high concentrations and under conditions that may convert it to nitrite, a much more toxic ion. Nitrite is readily absorbed into the bloodstream stream where it oxidizes ferrous iron in hemoglobin to the ferric state, forming methemoglobin. Methemoglobin cannot accept molecular oxygen, which reduces the oxygen-carrying capacity of the blood resulting in hypoxea or anoxia. Clinical signs of nitrate (nitrite) poisoning are dyspnea, cyanotic mucous mernbranes, and blood that is typically dark brown in color (Wolff and Wasserman 1972, Menzer 1991). Conditions that increase the hazard of nitrate (i.e., the conversion of nitrate to nitrite) are the presence of nitrogen-reducing microbes and low acidity in the gastrointestinal tract of warm-blooded animals. Human babies under 3 months have the lower acidity conditions in their digestive tracts characteristic of infant mammals and are at greater risk of nitrite formation than adults, assuming the presence of nitrogen-reducing microbes in the digestive tract. lllness has only been found in infants ingesting greater than $10 \mathrm{mg} / \mathrm{L}$ nitrate-nitrogen (NAS 1974). Therefore, a limit of $10 \mathrm{mg}$ nitrate-nitrogen/L has been imposed on drinking water by the USEPA to prevent methemoglobinemia in bottle-fed infants (WHO 1978, 1985).

In animals other than humans, nitrate poisoning has occurred at concentrations between 1000 and $3000 \mathrm{ppm}$ in water (Buck et al. 1976). Acute poisoning may also result from ingestion of plants that, under certain conditions, concentrate nitrate (Table 12.2). Conditions that lead to abnormal nitrate concentrations in these species of plants are high soil nitrate or ammonia levels, acid soil, low molybdenum, sulfur deficiency, low ambient temperature $\left(55^{\circ} \mathrm{F}\right)$, soil aeration, drought conditions and decreased light (Buck et al. 1976).

Nitrates accumulate in the vegetative tissue, not in grain or fruits and, in general, the concentrations are greater in the stalks than in the leaves (Buck et al. 1976). Acute toxicosis occurs in herbivores consuming forage containing more than $1.0 \%$ nitrate (dry weight basis) (Dollahite and Rowe 1974).

Ruminants are 2 to 3 times more susceptible to nitrate toxicity than monogastric animals (Emerick 1974). The LD50 for nitrate fed to cattle in forage is about $1 \mathrm{~g} / \mathrm{kg}$ body weight (Crawford et al. 1966). However, ruminants fed nitrate continuously become adapted to higher nitrate concentrations and nitrate levels in forage as high as 2 to $4 \%$ have been tolerated by ruminants (Buck et al. 1976).

Chronic nitrate poisoning is extremely rare and has not been readily verified in mammals (Tumer and Kienhoz 1972, Emerick 1974, Ridder and Oeheme 1974). A number of symptoms in domestic 
Ti to Accumulate Nitrate (from Jones and Hunt 1983; Buck et al. 1976)

fic Name
nthus retroflexus
podium spp.
n arvense
ispp.
thus anuus
iscoparia
parviflora
tus officinalis
ium spp.
: spp.
i kali
m marianum
im spp.
im halepense

Crop Plants

\section{Common Name}

Pigweed

Lamb's Quarters

Canada Thistle

Jimsonweed

Wild Sunflower

Fireweed

Cheeseweed

Sweet Clover

Smartweed

Dock

Russian Thistle

Varigated or "Bull" Thistle

Nightshades

Johnson Grass

Oats

Beets

Rape

Soybean

Flax

Alfalfa

Rye

Sudan grass

Wheat

Corn

anitto nitrate toxicosis, but no experimental evidence has been found to substanterference of thyroidal iodine uptake has been documented in some animal not been demonstrated in cattle and dogs (Ridder and Oeheme 1974). Horffect has been noted, and thyroid function usually returns to normal aftexposure. Nitrate may also dilate the arterioles causing lowered blood preie. 


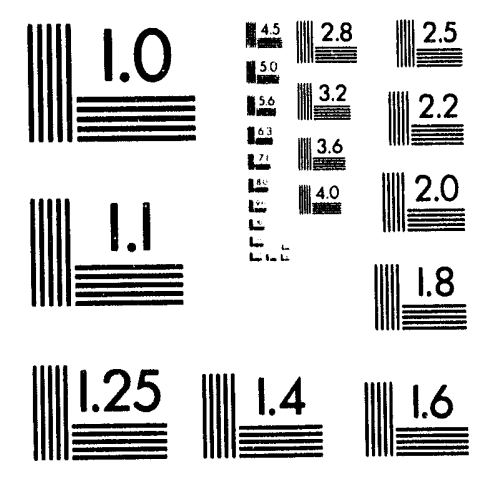



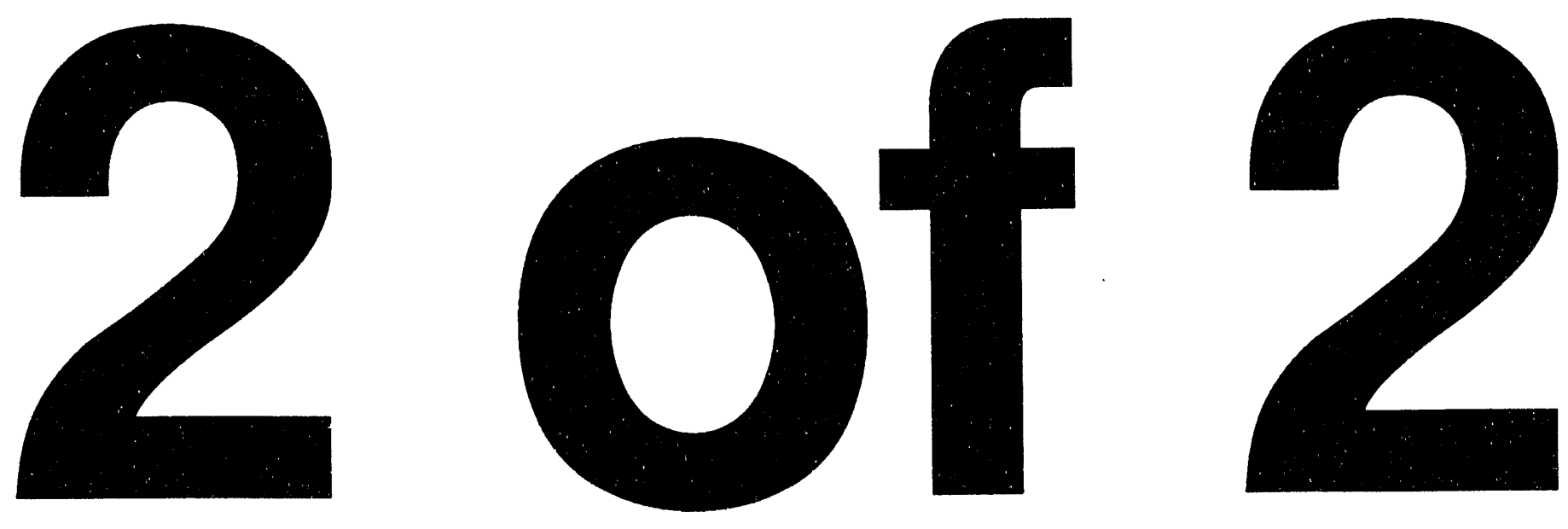


\subsection{Bioconcentration and Trophic Transfer Coefficients}

With the exception of certain plants growing under specific conditions, nitrate is readily eliminated from organisms and, therefore, does not usually accumulate or magnify in concentration along food chains. The accumulation of nitrate in plants is discussed above (Section 12.1.2). 


\subsection{References}

Aarkrog, A. 1971. "Radioecological Investigations of Plutonium in an Arctic Marine Environment." Health Phys. 20(1):31-47.

Abbasi, S. A., and R. Soni. 1983. "Stress-Induced Enhancement of Reproduction in Earthworm Octochaetus pattoni Exposed to Chromium (VI) and Mercury (II). Implications in Environmental Management." Int. J. Environ. Stud. 22:43-47.

Abraham, R. L. 1972. "Mortality of Mallards Exposed to Gamma Radiation." Radiat. Res. 49(2):322-327.

Adams, N., and N. L. Spoor. 1974. "Kidney and Bone Retention Functions in the Human Metabolism of Uranium." Phys. Med. Biol. 19:460-471.

Agency for Toxic Substances and Disease Registry (ATSDR). 1990a. Toxicological Profile for Uranium. TP-90-29, U.S. Department of Health and Human Services, Public Health Services, Agency for Toxic Substances and Disease Registry, Atlanta, Georgia.

Agency for Toxic Substances and Disease Registry (ATSDR). 1990b. Toxicological Profile for Plutonium. TP-90-21, U.S. Department of Health and Human Services, Public Health Services, Agency for Toxic Substances and Disease Registry, Atlanta, Georgia.

American Conference of Governmental Industrial Hygienists (ACGIH). 1986. Documentation of the Threshold Limit Values and Biological Exposure Indices. Fifth Edition. ACGIH, Cincinnati, Ohio.

American Public Health Association (APHA). 1980. Standard Methods for the Examination of Water and Wastewater. 15th ed. American Public Health Association, Washington, D.C.

Anderson, B. G. 1944. "The Toxicity Threshold of Various Substances Found in Industrial Wastes as Determined by the Use of Daphnia magna." Sewage Works J. 16:1156-1165.

Anderson, J. B., E. C. Tsivoglou, and S. D. Shearer. 1963. Effects of Uranium Mill Wastes on Biological Fauna of the Animas River (Colorado-New Mexico). In Radioecology, eds. V. Schultz and A. W. Klement, p. 373. Van Nostrand Reinhold, New York.

Anspaugh, L. R., J. J. Koranda, W. L. Robeson, and H. R. Martin. 1973. "The Dose to Man via Food Chain Transfer Resulting from Exposure to Tritiated Water Vapor." In Tritium, eds. A. A. Moghissi and M. W. Carter, pp. 405-422. Messenger Graphics, Phoenix, Arizona.

Atkins, P. G. 1977. Bioconcentration of Radionuclides in Aquatic Organisms. A Literature Review. Ontario Hydro Research Division, Aquatic Biology Section. Dept. No. 77-429K, Toronto, Ontario, Canada.

Avasthi, P. S., A. P. Evans, and D. Hay. 1980. "Glomerular Endothelial Cells in Uranyl NitrateInduced Acute Renal Failure in Rats." J. Clin. Incest. 65:121-127.

Bacq, Z. M., and P. Alexander. 1961. Fundamentals of Radiobiology. Pergamon Press, Inc., New York.

Bair, W., A. Wiggins, and L. Temple. 1962. "The Effect of Inhaled $\mathrm{Pu}^{239} \mathrm{O}_{2}$ on the Lifespan of Mice." Health Phys. 8:659-663.

Bair, W., J. Park, and W. Clarke. 1966. Long-Term Study of Inhaled Plutonium in Dogs. AFWL-TR-65-214, Air Force Weapons Laboratory, Kirtland Air Force Base, New Mexico. 
'Bair, W. J., J. F. Park, G. E. Dagle, and A. C. James. 1989. "Overview of Biological Consequences of Exposure to Plutonium and Higher Actinides." Rad. Prot. Dosimet. 26(1/4):125-135.

Bakke, O., K. Jakobsen, and K. B. Eik-Nes. 1984. "Concentration Dependent Effects of Potassium Dichromate on the Cell Cycle." Cytometry 5:482-486.

Balbi, C., D. Vecchio, P. Russo, S. Parodi, and L. Santi. 1981. "Specific Effects of Chromium Ion on DNA." Boll. Soc. It. Biol. Sp. 57:1143-1148.

Baudin, J. P., and R. Nucho. $1992 .{ }^{60}$ Co Accumulation from Sediment and Planktonic Algae by Midge Larvae (Chironomus luridus). Environ. Poll. 76:133-140.

Baudin, J. P., A. F. Fritsch, and J. Georges. 1990. "Influence of Labeled Food Type on the Accumulation and Retention of ${ }^{60} \mathrm{Co}$ by a Freshwater Fish, (Cyprinus carpio L). Water-Air-Soil Poll. 51(3-4):261-270.

Baudouin, M. F., and P. Scoppa. 1974. "Toxicity of Heavy Metals for Fresh Water Zooplankton: Influence of Some Environmental Factors." Boll. Zool. 41 (4):457.

Beasley, T. M., H. E. Palmer, and W. B. Nelp. 1966. "Distribution and Excretion of Technetium in Humans." Health Phys. 12:1425-1435.

Behari, W. O., S. V. Chandra, and S. K. Tandon. 1978. "Comparative Toxicity of Trivalent and Hexavalent Chromium to Rabbits. III. Biochemical and Histological Changes in Testicular Tissue." Actu. Bio. Med. Germ. 37:463-468.

Beliles, R. P. 1978. "The Lesser Metals." In Toxicity of Heavy Metals in the Environment, Part 2, ed. F. W. Oehme, pp. 547-616. Marcel Dekker, Inc., New York.

Bell, J., and T. Bates. 1988. "Distribution Coefficients of Radionuclides Between Soils and Groundwaters and Their Dependence on Various Test Parameters." Sci. Total Environ. 69:297-317.

Bellamy, A. W., J. L. Leitch, K. H. Larson, and D. B. Dunn. 1949. The 1948 Radiological and Biological Survey of Areas in New Mexico Affected by the First Atomic Bomb Detonation. UCLA-32, University of Califomia, Los Angeles, Califomia.

Belot, Y., D. Gauthier, H. Camus, and C. Caput. 1979. "Prediction of the Flux of Tritiated Water from Air to Plant Leaves." Health Phys. 37:575-583.

Benoit, D. A. 1976. Toxic Effects of Hexavalent Chromium on Brook Trout (Salvelinus fontinalis) and Rainbow Trout (Salmo gairdneri). Water Res. 10:497-500.

Bergamini, F. G., F. Palmas, F. Piantelli, and M. Sani. 1979. "Study on ${ }^{137}$ Cs Absorption by Lemna minor. Health Phys. 37:315-325.

Berry, W. L. 1978. Comparative Toxicity of $\mathrm{VO}^{3-} \mathrm{CrO}^{2-}{ }_{4}, \mathrm{MN}^{2+}, \mathrm{CO}^{2+}, \mathrm{Ni}^{2+}, \mathrm{Cu}^{2+}, \mathrm{Zn}^{2+}$, and $\mathrm{Cd}^{2+}$ to Lettuce Seedlings. In Proceedings of the Environmental Chemistry and Cycling Processes Symposium, eds. D. C. Adriano and I. L. Brisbin, Jr., pp. 582-589. April 28-May 1, 1976. CONF-760429, U.S. Department of Energy, Washington, D.C.

Bianchi, V., and A. G. Levis. 1986. "Mechanisms of Chromium Genotoxicity." Toxicol. Environ. Chem. 2:1-25. 
Bianchi, V., L. Celotti, G. Lanfranchi, F. Major, G. Marin, A. Montaldt, G. Sponza, G. Tamino, P. Venier, A. Zantedeschi, and A. Levis. 1983. "Genetic Effects of Chromium Compounds." Mutat. Res. 117:279-300.

Biber, T. U., M. Mylle, A. D. Bains, C. W. Gottschalk, J. R. Oliver, and M. MacDowell. 1968. "A Study by Micropuncture and Microdissection of Acute Renal Damage in Rats." Am. J. Med. 44:664-705.

Bice, D. E., D. L. Harris, C. T. Schnizlein, and J. L. Mauderly. 1979. "Methods to Evaluate the Effects of Toxic Materials Deposited in the Lung on Immunity in Lung Associated Lymph Nodes." Drug Chem. Toxicol. 2(1-2):35-48.

Blaylock, B. G., and J. P. Witherspoon. 1978. "Evaluation of Radionuclides Released from the Light Water Reactor Nuclear Fuel Cycle to the Aquatic Environment." Proceedings of the Environmental Chemistry and Cycling Processes Symposium, eds. D. C. Adriano and I. L. Brisbin, Jr., pp. 582-589. April 28-May 1, 1976. CONF-760429, U.S. Department of Energy, Washington, D.C.

Bloom, W. 1948. Histopathology of Irradiation from External and Internal Sources. McGraw-Hill Book Company, New York.

Boecker, B. B. 1972. "Toxicity of ${ }^{137} \mathrm{CsCl}$ in the Beagle: Metabolism and Dosimetry." Radiat. Res. 50:556-73.

Bond, V. P., T. M. Fliedner, and J. O. Archambeau. 1965. Mammalian Radiation Lethality: A Disturbance in Cellular Kinetics. Academic Press, New York.

Borghetti, A., A. Mutti, A. Cavatorta, M. Falzoi, F. Cigala, and I. Franchini. 1977. "Indices Renaux et d'Impregnation Chronique par le Chrome." Med. Lav. 68:355-363.

Bosshard, E., B. Zimmerli, and C. Schlatter. 1992. "Uranium in the Diet: Risk Assessment of its Nephro- and Radiotoxicity." Chemosphere 24(3):309-321.

Bowen, H. J. M. 1966. Trace Elements in Biochemistry. Academic Press, New York.

Bowen, H. J. M. 1979. Environmental Chemistry of the Elements. Academic Press, London, England.

Brandom, W. F., F. Saccomanno, V. E. Archer, and A. D. Bloom. 1978. "Chromosome Aberrations as a Biological Dose-Response Indicator of Radiation Exposure in Uranium Miners." Radiat. Res. 76:159-171.

Bringman, G., and R. Kuhn. 1959. "Water Toxicity Studies with Protozoa as Test Organisms." Gesund. Ing. 80:239-242.

Brisbin, I. L., Jr., R. A. Geiger, and M. H. Smith. 1973. "Accumulation and Redistribution of Radiocesium by Migratory Waterfowl Inhabiting a Reactor Cooling Reservoir." In Environmental Behavior of Radionuclides Released in the Nuclear Industry, p. 373. STI/PUB-345, International Atomic Energy Agency, Vienna, Austria.

Brooks, R. R. 1972. Geobotany and Biogeochemistry in Mineral Exploration. Harper and Row, New York.

Brooks, A., R. LaBauve, R. McClellan, and D. A. Jensen. 1976. "Chromosome Aberration Frequency in Blood Lymphocytes of Animals with ${ }^{239} \mathrm{Pu}$ Lung Burdens." In Radiation and the Lymphatic System. CONF-740930, National Technical Information Service, Springfield, Virginia. 
Brown, S. O., G. M. Krise, H. B. Page, and J. DeBoer. 1964. Effects of lonizing Radiation on the Reproductive System, eds. W. D. Carlson and F. S. Gassner, p. 103. Pergamon Press, Inc., New York.

Browning, E. 1969. Toxicity of Industrial Metals. 2nd ed. Butterworth, London, England.

Brunskill, G. J., and P. Wilkinson. 1987. "Annual Supply of Uranium-238, Uranium-234, Thorium230, Radium-226, Lead-210, Polonium-210, and Thorium-232 to Lake 239 (Experimental Lakes Area, Ontario, Canada) from Terrestrial and Atmospheric Sources." Can. J. Fish Aquat. Sci. 44(Suppl 1):215-230.

Buchsbaum, R. 1958. "Species Response to Radiation; Radioecology." In Radiation, Biology, and Medicine, ed. W. D. Claus, pp. 124-141. Addison-Wesley, Reading, Massachusetts.

Buck, W. B., G. D. Osweiler, and G. A. Gelder. 1976. Clinical and Diagnostic Veterinary Toxicology, 2nd edition. Kendall-Hunt Publishing Company, Dubuque, Iowa.

Buikema, A. L., Jr., J. Cairns, Jr., and G. W. Sullivan. 1974. Rotifers as Monitors of Heavy Metal Pollution in Water. Virginia Poltechnical Institute and State University Water Resources Research Center Bulletin 71.

Buldakov, L., Z. Kalmykova, A. Nifatov, V. Doshchenko, I. Tsevelera, G. Mushkacheva, N. Kudasheva, V. Peternikow, V. Matveev, A. Surina, and V. Karpova. 1972. "Metabolism and Biological Effects of Inhaled ${ }^{241} \mathrm{Am}$ and ${ }^{239} \mathrm{Pu}$ in Dogs." Health Phys. 22:873-874.

Bywater, J. F., R. Banaczkowski, and M. Bailey. 1991. "Sensitivity to Uranium of Six Species of Tropical Freshwater Fishes and Four Species of Cladocerans from Northem Australia." Environ. Toxicol. Chem. 10:1449-1458.

Cairns, J., Jr., and A. Scheier. 1959. "The Relation of Bluegill Sunfish Body Size to Tolerance of Some Common Chemicals." In Proceedings of the 13th Industrial Waste Conference, Purdue Univ., 1958. Purdue Univ. Eng. Bull. 43(3): 243-252.

Canadian Standards Association (CSA) 1987. Guidelines for Calculating Derived Release Limits for Radioactive Material in Airborne and Liquid Effluents for Normal Operation of Nuclear Facilities. National Standard of Canada. CAM/CSA-N288.1-M8, Canadian Standards Association, Rexdale, Toronto, Canada.

Cannon, H. L. 1960. "The Development of Botanical Methods of Prospecting for Uranium on the Colorado Plateau." U.S. Geol. Surv. Bull. 1085A:1-50.

Capodaglio, E., G. Catenacci, G. Pezzagno. 1975. "Functional Conditions of the Respiratory System and Worksite Pollution. II. Prevalence of Respiratory Function Changes in Workers Employed in Bichromate and Chromic Acid Production." Lav. Umano. 27:175-187.

Carraca, S., A. Ferreira, and J. Coimbra. 1990. "Sr Transfer Factors Between Different Levels in the Trophic Chain in Two Dams of Douro River (Portugal)." Wat. Res. 24(12):1497-1508.

Carritt, J., R. Fryxell, J. Kleinschmidt, R. Kleinschmidt, W. Langham, A. San Pietro, R. Schalffer, and B. Schnap. 1947. "The Distribution and Excretion of Plutonium Administered Intravenously to the Rat." J. Biol. Chem. 171:272-283.

Casarett, L. J. and J. Doulls. 1986. Toxicology: The Basic Science of Poisons. 3rd ed. MacMillan Publishing Co., New York.

Cataldo, D. A., and R. E. Wildung. 1978. "Soil and Plant Factors Influencing the Accumulation of Heavy Metals by Plants." Environ. Health Perspect. 27:149-159. 
Cataldo, D. A., and R. E. Wildung. 1983. "The Role of Soil and Plant Metabolic Processes in Controlling Trace Element Behavior and Bioavailability to Animals." Sci. Total Environ.

28:159-168.

Cataldo, D. A., R. E. Wildung, and T. R. Garland. 1978. "Technetium Accumulation, Fate, and Behavior in Plants." In Environmental Chemistry and Cycling Processes, eds. D. C. Adriano, T. L. Brisbin, Jr. Department of Energy Symposium Series No. 45, CONF-760429, pp. 538-549. National Technical Information Service, Springfield, Virginia.

Cataldo, D. A., R. E. Wildung, and T. R. Garland. 1987. "Speciation of Trace Inorganic Contaminants in Plant and Bioavailability to Animals: An Overview." J. Environ. Qual. 16(4):289-295.

Cataldo, D. A., T. R. Garland, R. E. Wildung, and R. J. Fellows. 1989. "Behavior and Effects of Technetiur. in Plants." Health Phys. 5Z(2):281-287.

Choi, I. C, and S. Aronoff. 1966. "Photosynthate Transport Using Tritiated Water." Plant Physiol. 41:1119-1129.

Cleland, W. W., and A. S. Mildvan. 1979. "Chromium (III) and Co (III) Nucleotides as Biological Probes." In Advances in Inorganic Biochemistry, Vol. I, pp. 163-191. Elsevier Applied Science Publ., New York.

Cochran, K. W., J. Doulls, M. Mazur, and K. P. Du Bois. 1950. "Acute Toxicity of Zirconium, Columbium, Strontium, Lanthium, Cesium, Tantalium, and Yttrium." Arch. Ind. Hyg. Occup. Med. 1:637-650.

Comar, C. L. 1965. "Movement of Fallout Radionuclides Through the Biosphere and Man." Ann. Rev. Nucl. Sci. 15:175-206.

Comar, C. L., and R. H. Wasserman. 1960. "Radioisotope Absorption and Methods of Elimination; Differential Behavior of Substances in Metabolic Pathways." In A Symposium on Radioisotopes in the Biosphere, eds. R. S. Caldecott and L. A. Snyder, p. 526. University of Minnesota, Minneapolis, Minnesota.

Comar, C. L., R. H. Wasserman, and M. M. Nold. 1956. "Strontium-Calcium Discrimination Factors in the Rat." Proc. Soc. Exp. Biol. Med. 92:859.

Commerford, S. L. 1984. "Tritium Metabolism in Mammals." In Proceedings of the European Seminar on the Risks from Tritium Exposure, eds. G. Gerber and C. Myttenaere, November 22-24. EUR 9065.

Commission of the European Communities. 1979. Methodology for Evaluating the Radiological Consequences of Radioactive Effluents Released in Normal Operations. Joint Report by the National Radiological Protection Board and the Commissariat a l'Energie Atomique; CEC; V/3865/79-EN, Luxembourg.

Commission of the European Communities. 1986. Technetium in the Environment. G. Desmet and C. Myttenaere, eds. CEC Radiation Protection Programme. Elsevier Applied Science Publ., London and New York.

Committee on the Biological Effects of Ionizing Radiations (CBEIR). 1980. The Effects on Populations of Exposure to Low Levels of Ionizing Radiation. Committee on the Biological Effects of Ionizing Radiations, National Research Council. National Academy Press, Washington, D.C. 
Committee on the Biological Effects of Ionizing Radiations (CBEIR). 1988. Health Risks of Radon and Other Internally Deposited Alpha Emitters. Committee on the Biological Effects of Ionizing Radiations, National Research Council. National Academy Press, Washington, D.C.

Committee on the Biological Effects of Ionizing Radiations (CBEIR). 1990. Health Effects of Exposure to Low Levels of lonizing Radiation. Committee on the Biological Effects of Ionizing Radiations, National Research Council. National Academy Press, Washington, D.C.

Crawford, R. F., W. K. Kennedy, and K. L. Davison. 1966. "Factors Influencing Toxicity of Forages that Contain Nitrate When Fed to Cattle." Cornell Vet. 56:1-17.

Cristy, M., and R. Leggett. 1986. Determination of Metabolic Data Appropriate for HLW Dosimetry. II. Gastrointestinal Absorption. NUREG/CR-3572 Vol. II. ORNL/TM-8932/V2, prepared by Oak Ridge National Laboratory for the U.S. Department of Energy, Washington, D.C.

Cumow, R. D, F. A. Glover, and F. W. Whicker. 1970. Radiosensitivity of the Mallard Duck (Anas platyrhynchos). Technical Paper 13, Colorado Cooperative Wildlife Research Unit, Colorado State University, Fort Collins, Colorado.

Cushing, C. E., and D. G. Watson. 1966. "Accumulation and Transport of Radionuclides by Columbia River Biota." In Proceedings of the Disposal of Radioactive Wastes into Seas, Oceans, and Surface Waters Symposium, pp. 551-570. STI/PUB/126, International Atomic Energy Agency, Vienna, Austria.

Cushing, C. E., and D. G. Watson. 1974. Aquatic Studies of Gable Mountain Pond. BNWL-1884, UC-48, Pacific Northwest Laboratory, Richland, Washington.

Cushing, C. E., J. M. Thomas, and L. L. Eberhardt. 1974. Modelling Mineral Cycling by Periphyton in a Simulated Stream System $\left({ }^{137} \mathrm{Cs}\right.$ and ${ }^{65} \mathrm{Zn}$ Tracer Studies). BNWL-SA-5120, Battelle Northwest Laboratories, Richland, Washington.

Dagle, G., R. Adee, R. Buschbom, K. M. Gideon, J. D. Kaschmitter, G. J. Powers, H. A. Ragan, C. O. Ramos, R. E. Weller, and E. L. Weirman. 1988. "Inhaled Plutonium Nitrate in Dogs. Part 1. Biomedical Sciences." 1987 Annual Report for U.S. Department of Energy, Office of Energy Research. PNL-6500, Pacific Northwest Laboratory, Richland, Washington.

Dagle, G., J. Park, R. Weller. 1985. "Skeletal Lesions from Inhaled Plutonium in Beagles." In Metals in Bone, ed. N. Priest, pp. 333-341. MTP Press, Lancaster, England.

Danenberg, K. D., and W. W. Cleland. 1985. "Use of Chromium-Adenosine Triphosphate and Lyxose to Elucidate the Kinetic Mechanism and Coordination State of the Nucleotide Substrate for Yeast Hexokinase." Biochem. 14:28-39.

David, A., and J. Harrison. 1984. "The Absorption of Ingested Neptunium, Plutonium and Americium in Newbom Hamsters." Int. J. Radiat. Biol. 46:279-286.

Davies, P. H. 1980. Acute Toxicity to Brook Trout (Salvelinus fontinalis) and Rainbow Trout (Salmo gairdneri) in Soft Water. Water Pollution Studies Project F-33-R. Federal Aid in Fish and Wildlife Restoration, Job Progress Report F-33-R-15. Colorado Division of Wildlife, Fort Collins, Colorado. Cited from Guidelines for Surface Water Quality, Vol. 1, Inorganic Chemical Substances. Inland Waters Directorate, Ottawa, Canada.

DeFloro, S., and K. E. Wetterhahn. 1989. "Mechanisms of Chromium Metabolism and Genotoxicity." Life Chem. Rep. 1:169-244. 
Denniston, M. L., and E. M. Uyeki. 1987. "Distribution and HPLC Study of Chromium-51 Binding Sites in Chinese Hamster Ovary Cells." J. Toxicol. Environ. Health 21:375-386.

DePamphilis, M. L., and W. W. Cleland. 1973. "Preparation and Properties of Cr(III)-Nucleotide Complexes for Use in the Study of Enzyme Mechanisms." Biochem. 12:3714-3724.

DeRay, B. M., H. E. Lanfranchi, and R. L. Cabrini. 1983. "Percutaneous Absorption of Uranium Compounds." Environ. Res. 30:480-491.

Diabate, S., and S. Strack. 1990. Doses Due to Tritium Releases by NET-Data Base and Relevant Paramenters on Biological Tritium Behavior. KfK 4713, Kernforschungszentrum Karlsruhe GmbH, Karlsruhe. ISSN 0303-4003.

Diamond, G. L. 1989. "Biological Consequences of Exposure to Soluble Forms of Natural Uranium." Radiat. Prot. Dosimet. 26(1/4)23-33.

Diamond, G. L., R. M. Gelein, P. E. Morrow, B. J. Panner, and R. B. Baggs. 1987. Nephrotoxicity of Uranyl Fluoride and Reversibility of Renal Injury in the Rat. NUREG/CR-4951, U.S. Nuclear Regulatory Commission, Washington, D.C.

Dollahite, J. W., and L. D. Rowe. 1974. "Nitrate and Nitrite Intoxication in Rabbits and Cattle." Southwestern Vet. 27:246.

Dolphin, G. W., and I. S. Eve. "The Metabolism of Strontium in Adult Humans." Physics Med. Biol. 8:193-203.

Domingo, J. L., J. M. Llobet, J. M. Tomás, and J. Corbella. 1987. "Acute Toxicity of Uranium in Rats and Mice." Bull. Environ. Contam. Toxicol. 39:168-174.

Domingo, J. L., A. Ortega, J. L. Patemain, and J. Corbella. 1989a. "Evaluation of the Perinatal and Postnatal Effects of Uranium in Mice Upon Oral Administration." Arch. Environ. Health 44:395-398.

Domingo, J. L., J. L. Paternain, J. M. Llobet, and J. Corbella. 1989b. "The Development Toxicity of Uranium in Mice." Arch. Environ. Health 33:395-398.

Donaldson, R. M., and F. F. Barreras. 1966. "Intestinal Absorption of Trace Quantities of Chromium." J. Lab. Clin. Med. 68:484-493.

Dowden, B. F. and H. T. Bennett. 1965. "Toxicity of Selected Chemicals to Certain Animals." J. Water Pollut. Control Fed. 37(9):1308-1316.

Dreesen, D. R., M. J. Williams, M. L. Marple, E. S. Gladney, and D. R. Perrin. 1982. "Mobility and Bioavailability of Uranium Mill Tailings Contaminants." Environ. Sci. Technol. 16:702-709.

Dunaway, P. B., L. L. Lewis, J. D. Story, J. A. Payne, and J. M. Inglis. 1969. "Radiation Effects in the Soricidae, Cricetidae, and Muridae." In Symposium on Radioecology, eds. D. J. Nelson and F. C. Evans, pp. 173-184. CONF-670503, CFSTI, National Bureau of Standards, Springfield, Virginia.

Dunford, W. E., O. E. Acres, and R. W. Pollock. 1985. Concentration of ${ }^{137}$ Cs in Water and Fish from the Winnipeg River, Canada. AECL-8098, IAEA-SR-85/13, Atomic Energy of Canada Limited, Whiteshell Nuclear Research Establishment, Pinawa, Manitoba, Canada.

Durbin, P. W. 1960. "Metabolic Characteristics Within a Chemical Family." Health Phys. 2:225238. 
Eaton, D., and C. E. Murphy, Jr. 1992. Tritium Uptake by Fish in a Small Stream (U).

WSRC-TR-92-193, Rev 1. Westinghouse Savannah River Company, Aiken, South Carolina.

Eisler, R. 1985. Chromium Hazards to Fish, Wildlife, and Invertebrates: A Synoptic Review. Contaminant Hazard Reviews Report 85-6. U. S. Fish and Wildlife Service, U.S. Department of the Interior, Washington, D.C.

Eisler, R. 1985. Carbofuran Hazards to Fish, Wildlife, and Invertebrates: A Synoptic Review. Biology Report 85(1.3), U.S. Fish and Wildlife Service, Patuxent Wildlife Research Center, U.S. Department of the Interior, Laurel, Maryland.

Ekman, L. 1967. "Mechanisms of Uptake and Accumulation of Radionuclides in Terrestrial Animals." In Radioecological Concentration Processes, eds. B. Aberg and F. P. Hungate, pp. 547-560. Pergamon Press, Inc., Oxford, England.

Ekman, L., and G. Aberg. 1961, "Excretion of Niobium-95, Yttrium-91, Cerium-144, and Promethium-147 in Goats." Res. Vet. Sci. 2:100.

Emerick, R. J. 1974. "Consequences of High Nitrate Levels in Feed and Water Supplies." Fed Proc. 33:1183.

Emery, R. M., and T. R. Farland, 1974. Ecological Behavior of Plutonium and Americium in a Freshwater Ecosystem. Phase II. Implications of Differences in Transuranic Isotope Ratios. USAEC Report BNWL-1879, Battelle, Pacific Northwest Laboratories.

Emery, R. M., D. C. Klopfer, and W. C. Weimer. 1974. Ecological Behavior of Plutonium and Americium in a Freshwater Ecosystem. Phase I. Limnological Characterization and Isotopic Distribution. USAEC Report BNWL-1867, Battelle Northwest Laboratories, Richland, Washington.

Emery, R. M., D. C. Klopfer, T. R. Farland, and W. C. Weimer. 1975a. "Ecological Behavior of Plutonium and Americium in a Freshwater Pond." In Radioecology and Energy Resources, ed. C. E. Cushing, Jr., Ecological Society of America, Special Publication No. 1. Dowden, Hutchinson \& Ross, Inc., Stroudsburg, Pennsylvania.

Emery, R. M., D. C. Klopfer, T. R. Farland, and W. C. Weimer. 1975b. Ecological Behavior of Plutonium and Americium in a Freshwater Pond. USAEC Report BNWL-SA-5346, Battelle Northwest Laboratories, Richland, Washington.

Emery, R. M., D. C. Klopfer, and M. C. McShane. 1980. "The Migration of Plutonium from a Freshwater Ecosystem at Hanford." In Transuranic Elements in the Environment, ed. W. Hanson, pp. 625-643. DOE/TIC-22800, National Technical Information Service, Springfield, Virginia.

Environment Canada. 1978. Monitoring Program Design Recommendations for Uranium Mining Localities, Environment Canada. Environmental Protection Service, Ottawa, Ontario, Canada.

Etoh, H., and Y. Hyodo-Taguchi. 1983a. "Effects of Tritiated Water on Germ Cells in Medaka Embryos." Radiat. Res. 93:332-339.

Etoh, H., and Y. Hyodo-Taguchi. 1983b. "Effects of Beta-Rays from Tritiated Water on Germ Cells in Medaka Embryos and Fry." In Proceedings of the Seventh International Congress of Radiation Research, eds. J. J. Broerse, G. W. Barendsen, H. B. Kal, and A. J. Van Der Kogel, C3-05. Martinus Nijhoff, Amsterdam, The Netherlands.

Evans, E. J., and A. J. Dekker. 1962. "Comparative $\mathrm{Sr}^{90}$ Content of Agricultural Crops Grown in a Contaminated Soil." Can. J. Plant Sci. 42:252-258. 
Eyman, L. D., and J. R. Trablaka. 1980. "Patterns of Transuranic Uptake by Aquatic Organisms: Consequences and Implications." In Transuranic Elements in the Environment, ed. W. Hanson, pp. 612-624. DOE/TIC-22800, National Technical Information Service, Springfield, Virginia.

Fielitz, U. 1991. Schriftenreihe Reaktorsicherheit und Strahlenshutz. BMU-1991-294, Bundesministerium fuer Umwelt, Naturshcutz und Reaktorsicherheit, Inst. furer Wildbiologie und Jagdkunde, Bonn, Germany.

Finch, R. R. 1983. Metabolic Effects and Distribution Studies of $T c^{99}$ in Soybeans. San Diego State Univ. Thesis.

Fisher, A. A. 1986. Contact Dermatitis, 3rd Edition, p. 36. Lea \& Febiger, Philadelphia, Pennsylvania.

Franchini, I., A. Mutti, and A. Cavatorta. 1978. "Nephrotoxicity of Chromium. Remarks on an Experimental and Epidemiological Investigation." Conir. Nephr. 10:1058-1063.

French, N. R. 1965. "Radiation and Animal Populations: Problems, Progress and Projections." Health Phys. 11:1557-1568.

French, N. R., B. G. Maza, H. O. Hill, A. P. Aschwanden, and H. W. Kaaz. 1974. "A Population Study of Irradiated Desert Rodents." Ecol. Mono. 442(1):45-72.

French, N. R. 1975. Chronic Low-Level Gamma Irradiation of a Desert Ecosystem for Five Years. In Actes du Symposium International de Radioecologie, Vol. 2, pp. 1151-1165. Centre d'Etudes Nucleaires de Cadarche, France.

Friberg, L. 1977. Toxicology of Metals, Vol. 2. EPA-600/1-77-022, U.S. Environmental Protuction Agency, Office of Research and Development, Health Effects Research Laboratories.

Fritsch, P., M. Beauvallet, K. Moutairou, H. Metivier, and R. Masse. 1987. "Acute Lesions Induced by Alpha-Irradiation of Intestine After Plutonium Gavage of Neonatal Rats." Int. J. Radiat. Stud. Phys. Chem. Med. 52:1-6.

Fromm, P. O., and R. H. Schiffman. 1958. "Toxic Action of Hexavalent Chromium on Largemouth Bass." J. Wildl. Manage. 22(1):40-44.

Gale, T. F. 1978. "Embryotoxic Effects of Chromium Trioxide in Hamsters." Environ. Res. 16:101-109.

Galibin, G. P., A. L. Pozdnyakov, and L. I. Murav'eva. 1966. "Biological Effects of Ammonium Diuranate Following Prolonged Inhalation." Gig. Sanit. Hyg. Sanit. 31(10-12):338-344.

Gambino, J. J., and R. G. Lindberg. 1964. "Response of the Pocket Mouse to Ionizing Radiation." Radiat. Res. 22:586-597.

Garg, S. P., A. Zajanc, and R. A. Bankowski. 1964. "The Effect of Cobalt-60 on Starlings (Sturnus vulgaris ). Avian Dis. 8:555-561.

Garland, T. R., and R. E. Wildung. 1977. "Physicochemical Characterization of Mobile Plutonium Species in Soils." In Biological Implications of Metals in the Environment, pp. 254-263.

Proceedings of the Fifteenth Annual Hanford Life Sciences Symposium, Scptember 29-October 1, 1975, Richland, Washington. CONF-750929, U.S. Department of Energy, Washington, D.C. 
Garland, T. R., D. A. Cataldo, and R. E. Wildung. 1981. "Absorption, Transport, and Chemical Fate of Plutonium in Soybean Plants." J. Agric. Food Chem. 29:915-920.

Garland, T. R., D. A. Cataldo, K. M. McFadden, R. G. Schreckhise, and R. E. Wildung. 1983. "Comparative Behavior of ${ }^{99} \mathrm{Tc},{ }^{129} \mathrm{I},{ }^{127} \mathrm{I}$ and ${ }^{137} \mathrm{Cs}$ in the Environment Adjacent to a Fuels Reprocessing Facility." Health Phys. 44(6):658-662.

Garland, T. R., D. A. Cataldo, K. M. McFadden, and R. E. Wildung. 1987. "Factors Affecting Absorption, Transport, and Form of Plutonium in Plants." In Environmental Research on Actinide Elements, eds. J. E. Pinder, J. J. Alberts, K. W. McLeod, and R. G. Schreckhise, pp. 83-95. U.S. Department of Energy, Washington, D.C.

Garner, R. J. 1963. "Environmental Contamination and Grazing Animals." Health Phys. 2:597-605. Garner, R. J., H. G. Jones, and L. Ekman. 1960. "Fission Products and the Dairy Cow: The Fate of Orally Administered Cerium-144." J. Agric. Sci. 55:107.

Garten, C. T., Jr., E. A. Bondietti, J. R. Trabalka, R. L. Walker, and T. G. Scott. 1987. "Field Studies on Terrestrial Behavior of Actinide Elements in East Tennessee." In Environmental Research on Actinide Elements, eds., J. E. Pinder, J. J. Alberts, K. W. McLeod, and R. G. Schreckhise, pp. 109-119. U.S. Department of Energy, Washington, D.C.

Gearing, P., C. VanBaalen, P. L. Parker. 1971. "Response of Blue-Green Algae to Technetium." In Radionuclides in Ecosystems, ed. D. J. Nelson, p. 2:240. Oak Ridge National Laboratory, Oak Ridge, Tennessee.

George, L. S., C. E., Dallas, I. L. Brisbin, Jr., and D. L. Evans. 1991. "Flow Cytometric DNA Analysis of Ducks Accumulating ${ }^{137} \mathrm{Cs}$ on a Reactor Reservoir." Ecotoxicol. Environ. Safety 21:337347.

Gerber, G. B., M. Van Hees, C. T. Garten, Jr., C. M. Vandecasteele, J. K. Vankerkom, R. Van Bruwaene, R. Kirchmann, J. Colard, and M. Cogeneau. 1989. "Technetium Absorption and Tumover in Monogastic and Polygastric Animals." Health Phys. 57:(2) 315-319.

Gerking, S. D., A. Berg, and P. Gerard. 1976. "Rate of Sediment Uptake by Midge Larvae (Chironomus plumosus: Diptera)." In Radioecology and Energy Resources, ed. C. E. Cushing, pp. 126-135. Dowden, Hutchinson, and Ross, Stroudsburg, Pennsylvania.

Giles, M. S. 1964. "Toxicity Studies on Aquatic Organisms and Grass-Edge Communities in the Magela Creek Area." In Alligator Rivers Area Fact Finding Study, Australian Atomic Energy Commission Report 2, Australian Government Publishing Service, Canberra, Australia Capital Territory, Australia.

Giliano, S. H., and M. Marano. 1979. "Chromium Poisoning and Chick Embryogenesis." Environ. Res. 12:427-431.

Gilett, N. A., B. A. Muggenburg, J. A. Mewhinney, F. F. Hahn, F. A. Seiler, B. B. Boecher, and R. O. McClellan. 1988. "Primary Liver Tumors in Beagle Dogs Exposed by Inhalation to Aerosols of Plutonium-238 Dioxide." Am. J. Pathol. 133:265-276.

Gleiser, C. A. 1953. "The Determination of the Lethal Dose 50/30 of Total Body X-Radiation for Dogs." Am. J. Vet. Res. 14:284-286.

Gohar, H. A. F., and H. El-Gindy. 1961. "Tolerance of Vector Snails of Bilharziasis and Fasciolaisis to Some Chemicals." Proc. Egypt. Acad. Sci. 16:37-48. 
Gough, L. P., H. T. Shacklette, and A. A. Case. 1979. "Element Concentrations Toxic to Plants, Animals, and Man." U.S. Geol. Surv. Bull. 1466:52-55.

Goyer, R. A. 1986. "Toxic Effects of Metals." In Casarett and Doulls Toxicology, The Basic Science of Poisons, 3rd edition, eds. C. D. Klaassen, M. O. Amdur, and J. Doulls, pp. 582-635. Pergamon Press, Inc., New York.

Goyer, R. A. 1991. "Toxic Effects of Metals." In Casarett and Doulls Toxicology, The Basic Science of Poisons, 4th edition, eds. M. O. Amdur, J. Doulls, and C. D. Klaassen, pp. 623-680. Pergamon Press, Inc., New York.

Greb, R. J. 1955. "Lethal X-Ray Dose in Pheasants." Proc. S. D. Acad. Sci. 34:104.

Greb, R. J., and W. Morgan. 1961. "Treatment of Pheasant Ovaries with X-Rays and Gamma Rays." Proc. S. D. Acad. Sci. 40:112.

Gross, F., and F. F. Koczy. 1946. "Photometric Measurements of the Growth of Phytoplankton Cultures." Medd. Oceanogr. Inst. No. 10.

Gross, W. G, and U. G. Heller. 1946. "Chromium in Animal Nutrition." J. Ind. Hyg. Toxicol. 28:52-56.

Guenot, J., and Y. Belot. 1984. "Assimilation of H-3 in Photosynthesizing Leaves Exposed to HTO." Healtin Phys. 47:849-855.

Guglielmotti, M. B., A. M. Ubios, B. M. DeRey, and R. L Cabrini. 1084. "Effects of Acute Intoxication with Uranyl Nitrate on Bone Formation." Experimentia 40:474-476.

Guilmette, R., J. Diel, B. Muggenburg, J. A. Mewhinney, B. R. Boecker, and R. O. McClellan. 1984. "Biokinetics of Inhaled Plutonium-239 Dioxide in the Beagle Dog: Effect of Aerosol Particle Size." Int. J. Radiat. Biol. Relat. Stud. Phys. Chem. Med. 45:563-581.

Gus'kova, V. N., L. N. Gurfein, and A. I. Tikhonova. 1966. "Uranium Action in a Reservoir." Gidrobiol. Zh. 2(6):53-57. Cited from Guidelines for Surface Water Quality, Vol. 1, Inorganic Chemical Substances. 1983 Environment Canada, Inland Waters Directorate, Water Quality Branch, Ottawa, Canada.

Guthrie, J. E., and J. R. Dugel. 1983. "Gamma-Ray Irradiation of a Boreal Forest Ecosystem: The Field Irradiator-Gamma (FIG) Facility and Research Programs." Can. Field Nat. 27:120-128.

Hajec, B. F. 1966. Plutonium and Americium Mobility in Soils. BNWL-CC-925, Battelle Northwest Laboratories, Richland, Washington.

Hakonson, T. E., and L. J. Johnson. 1973. Distribution of Environmental Plutonium in the Trinity Site Ecosystem After 27 Years. LA-UR-73-1291, Los Alamos Scientific Laboratory, Los Alamos, New Mexico.

Hakonson, T. E. 1975. "Environmental Pathways of Plutonium into Terrestrial Plants and Animals." Health Phys. 29:583-588.

Haley, D. P. 1982. "Morphologic Changes in Uranyl Nitrate-Induced Acute Renal Failure in Salineand Water-Drinking Rats." Lab Invest. 46:196-208.

Haley, D. P., R. E. Bulger, and D. C. Dobyan. 1982. "The Long-Term Effect of Uranyl Nitrate on the Structure and Function of the Rat Kidney." Virchows Arch. (Cell Pathol.) 4:181-192. 
Haley, T. J. 1965. "Pharmacology and Toxicology of Rare-Earth Elements." J. Phar. Sci. 54:663-670.

Haley, T. J. 1977. "Toxicology." In Handbook on the Physics and Chemistry of Rare Earths, Vol. 4, eds. K. A. Gschneider and L. Eyring. North-Holland, New York.

Hansen, K., and R. M. Stern. 1986. "A Survey of Metal-Induced Mutagenicity in Vitro and in Vivo." In Carcinogenic and Mutagenic Metal Compounds: Environmental and Analytical Chemistry and Biological Effects, eds. E. Merian, R. W. Frei, W. Hardi, and C. Schlater, pp. 207-212. Gordon and Breach Science Publishers, New York.

Hanson, W. C. 1975. "Ecological Considerations of the Behavior of Plutonium in the Environment." Health Phys. 28:529-537.

Hanson, W. C., and H. A. Kronberg. 1956. "Radioactivity in Terrestrial Animals Near an Atomic Energy Site." In Proceedings of the International Conference on Peaceful Uses of Atomic Energy. 13:385-388.

Hanson, W. C., and D. G. Watson. 1960. "Radioactive Contamination in Wildlife-1959." In Hanford Biology Research Annual Report for 1959, Report HW-65500, USAEC, p. 171. Hanford Atomic Products Operation, General Electric Co.

Hanson, W. C., D. G. Watson, and R. W. Perkins. 1967. "Concentration and Retention of Fallout Radionuclides in Alaskan Arctic Ecosystems." In Radioecological Concentration Processes, eds. B. Aberg and F. P. Hungate, pp. 233-245. Pergamon Press, Inc., Oxford, England.

Harley, N. H. 1991. "Toxic Effects of Radiation and Radioactive Materials." In Casarett and Doulls Toxicology, The Basic Science of Poisons, 4th edition, eds. M. O. Amdur, J. Doulls, and

C. D. Klaassen, pp. 723-752. Pergamon Press, Inc., New York.

Harper, P. V., K. A. Lathrop, R. J. McCardle, and G. Andros. 1964. "The Use of Technetium-99m as a Clinical Scanning Agent for Thyroid, Liver and Brain." In Proceedings of the Symposium on Medical Radioisotope Scanning, Vol. II, Vienna International Atomic Energy Agency, pp. 33-45.

Harrison, J. D., and J. W. Stather. 1981. "The Gastrointestinal Absorption of Protactinium, Uranium and Neptunium in the Hamster." Radiat. Res. 88:47-55.

Harrison, S. E., J. G. Klaverkamp, and R. H. Hesslein. 1990. "Fates of Metal Radiotracers Added to a Whole Lake: Accumulation in Fathead Minnow (Pimephales promelas) and Lake Trout (Salvelinus nanaycus)." Water, Air, Soil Pollution 52:277-293.

Hart, H. E., G. Greenburg, R. Levin, H. Spencer, K. G. Stem, and A. D. Lazlo. 1955. "Metabolism of Lanthanum and Yttrium Chelates." J. Lab. Clin. Med. 46:182-192.

Hatch, F. T., and J. A. Mazrimas. 1972. "Tritiation of Animals from Tritiated Water." Radiat. Res. 50:339-357.

Hatherhill, J. R. 1981. "A Review of the Mutagenicity of Chromium." Drug Chem. Toxicol. $4: 185-195$.

Haven, F. L., and H. C. Hodge. 1949. "Toxicity Following the Parenteral Administration of Certain Soluble Uranium Compounds." In Pharmacology and Toxicology of Uranium Compounds, Vol. 1, eds. C. Voegtlin and H. Hodge, pp. 281-308. McGraw Hill Book Company, New York.

Heinz, G. H., and S. D. Haseltine. 1981. "Avoidance Behavior of Young Black Ducks Treated with Chromium." Toxicol. Lett. $\underline{8}: 307-310$. 
Hewett, C. J., and D. F. Jefferies. 1976. "Accumulation of Radioactive Caesium from Water by the Brown Trout (Salmo trutta) and Its Comparison with Plaice and Rays." J. Fish Biol. 2:479-489.

Hicks, R., P. J. Hewitt, and H. F. Lam. 1979. "An Investigation of the Experimental Induction of Hypersensitivity in the Guinea Pig on Material Containing Chromium, Nickel, and Cobalt from Arc Welding Fumes." Int. Arch. Allergy Appl. Immunol. 52:265-272.

Hodge, H. C., H. E. Stokinger, W. F. Neuman, W. F. Bale, and A. E. Brandt. 1953. "Maximum Allowable Concentration of Uranium Dust in Air." Chapter 26 in Pharmacology and Toxicology of Uranium Compounds, eds. C. Voegtlin and H. C. Hodge, pp. 2104-2256. McGraw-Hill Book Company, New York.

Hoffman, F. O., J. W. Huckabee, D. M. Lucas, C. T. Garten, T. G. Scott, R. L. Walker, P. S. Gouge, and C. V. Holmes. 1980. Sampling of Technetium-99 in Vegetation and Soils in the Vicinity of Operating Gaseous Diffusion Facilities. ORNL/TM-7386, Oak Ridge National Laboratory, Oak Ridge, Tennessee.

Hohreiter, D. W. 1980. Toxicities of Selected Substances to Freshwater Biota. ANL/ES-94, Report to Department of Energy, Washington D.C., by Argonne National Laboratory, Argonne, Illinois.

Holdway, D. A. 1992. "Uranium Toxicity to Two Species of Australian Tropical Fish." Sci. Total Environ. 125:137-158.

Hopkins, L. L. Jr. 1965. "Distribution in Therapy of Physiological Amounts of Injected $\mathrm{Cr}^{50}(+3)$ with Time." Amer. J. Physiol. 209:731-735.

Hopkins, L. L., Jr., and K. Schwarz. 1964. "Chromium Binding to Serum Proteins, Specifically Siderophilin." Biochim. Biopys. Acta 20:484-491.

Horikoshi, T., A. Nakajima, and T. Sakaguchi. 1981. "Studies on the Accumulation of Heavy Metal Elements in Biological Systems. XIX. Accumulation of Uranium by Micro-organisms." Eur. J. Appl. Microbiol. Biotechnol. 12:90-96.

Horsic, E., Z. Milsevic, R. Kljajic., and A. Bauman. 1982. "Concentration Factors and Absorbed Doses of Sr-90 and Cs-137 in the Sava River Fishes." In Proceedings of the Third International Symposium on Radiological Protection--Advances in Theory and Practice (I), pp. 110-113, Society for Radiological Protection, June 6-11. 1982, Inverness, Scotland.

Hunter, W. C., and J. M. Roberts. 1933. "Experimental Study of the Effects of Potassium Dichromate on the Monkey's Kidney." Am. J. Pathol. 2:133-147.

Hursh, J. B., and N. L. Spoor. 1973. "Data on Man." In Handbook of Experimental Pharmacology. Uranium, Plutonium, and Transplutonic Elements, Vol. 36, eds. H. C. Hodge, J. N. Stannard, and J. B. Hursh. Springer-Verlag, New York.

Hursh, J. B., W. R. Neuman, T. Toribara, H. Wilson, and C. Waterhouse. 1969. "Oral Ingestion of Uranium by Man." Health Phys. 17:619-621.

Hutcheson, D. P., D. H. Gray, B. Venugopal, T. D. Luckey. 1975a. "Nutritional Safety of Some Heavy Metals in Mice." J. Nutr. 105:670-675.

Hutcheson, D. P., D. H. Gray, B. Venugopal, T. D. Luckey. 1975b. "Safety of Heavy Metals as Nutritional Markers." Environ. Qual. Saf., Suppl. 1:74-80.

Hyne, R. V., G. D. Rippon, and G. Ellender. 1991. "pH-Dependent Uranium Toxicity to Freshwater Hydra." Sci. Total Environ. 125:159-174. 
Hyne, R. V., G. D. Rippon, and G. Ellender. 1991. "pH-Dependent Uranium Toxicity to Freshwater Hydra." Sci. Total Environ. 125:159-174.

Hyne, R. V., G. D. Rippon, J. White, and G. Ellender. 1992. "Accumulation of Uranium by Freshwater Hydra into Discharged Nematocysts." Aquatic Toxicol. 23:231-246.

Hyodo-Taguchi, Y., and H. Etoh. 1986. "Effects of Tritiated Water on Germ Cells in Medaka. II. Diminished Reproductive Capacity Following Embryonic Exposure." Ratiat. Res. 106:321-330.

IAEA. 1980. Elemental Analysis of Biological Materials. No. 197, International Atomic Energy Agency, Vienna, Austria.

Iijima, S., N. Matsumoto, C. C. Lu, and H. Katsunuma. 1979. "Embryotoxic and Fetotoxic Effects of Chromium Trioxide in Mice." Teratology 20:152.

Intemational Commission on Radiological Protection (ICRP). 1964. Supplement to Report of Committee 11 on Permissible Dose for Internal Radiation (ICRP Pub. 2), ICRP Pub. 6, Pergamon Press, Inc., Oxford, England

International Commission on Radiological Protection (ICRP). 1975a. Reference Man: Anatomical, Physiological and Metabolic Characteristics, No. 23. Pergamon Press, Inc., Oxford, England.

International Commission on Radiological Protection (ICRP). 1975b. Report of the Task Group on Reference Man, No. 23. Pergamon Press, Inc., Oxford, England.

International Commission on Radiological Protection (ICRP). 1979. Limits for Intakes of Radionuclides by Workers. ICRP Publication 30, Part 1, Ann. ICRP 2(3/4), International Commission on Radiological Protection, Pergamon Press, Inc., Oxford, England.

International Commission on Radiological Protection (ICRP). 1986. The Metabolism of Plutonium and Related Elements. ICRP Publication 48, Part 1, Ann. ICRP 16(2/3), Intemational Commission on Radiological Protection, Pergamon Press, Inc., Oxford, England.

Jacobson, L., and R. Overstreet. 1948. "The Uptake of Plutonium and Some Products of Nuclear Fission Absorbed on Soil Colloids." Soil Sci. 65:129-134.

James, B. R., and R. J. Bartlett. 1983a. "Behavior of Chromium in Soils. V. Fate of Organically Complexed Cr (III) Added to Soil." J. Environ. Qual. 12:169-172.

James, B. R., and R. J. Bartlett. 1983b. "Behavior of Chromium in Soils. VI. Interactions Between Oxidation-Reduction and Organic Complexation." J. Environ. Qual. 12:173-176.

Jones, B. E. V. 1989. "Technetium Metabolism in Goats and Swine." Health Phys. 57:331-336.

Jones, J. R. E. 1939. "The Relation Between the Electrolytic Solution Pressures of the Metals and Their Toxicity to the Stickleback (Gasterosteus aculeatus L.)." Sewage Ind. Wastes 25:802.

Jones, J. R. E. 1940. "A Further Study of the Relation Between Toxicity and Solution Pressure, with Polycelia nigraas Test Animal." J. Exp. Biol. 17(4):408-415.

Jones, T. C., and R. D. Hunt. 1983. Veterinary Pathology. Fifth Edition. p.887. Lea and Febiger, Philadelphia, Pennsylvania.

Jouany, J. M., P. Vasseur, and J. F. Ferard. 1982. "Short and Medium Term Toxicity of Hexavalent Chromium to Chlorella vulgaris and Daphnia magna." Envrion. Pollut., Ser A. (United Kingdom) 27(3):207-221. 
Kabata-Pendias, A., and H. Pendias. 1984. Trace Elements in Soils and Plants, pp. 147. CRC Press, Boca Raton, Florida.

Kanazawa, T., K. Kanazawa, and J. A. Bassham. 19'72. "Tritium Incorporation in the Metabolism of Chlorella Pyrenoidosa." Environ. Sci. Techn. 6:638-642.

Katz, S. A. 1991. "The Analytical Biochemistry of Chromium." Environ. Health Perspect. 22:1316.

Kelly , P., J. P. Day, M. O'Hara, C. Tye, C. Burton, and M. Harris. 1982. "Cutaneous Absorption of Trivalent Chromium: Tissue Levels and Treatment by Exchange Transfusion." Br. J. Ind. Med. 22:397-400.

Kennedy, C. W., and Bartelt. 1978. "Distribution of ${ }^{238} \mathrm{Pu}$ in Tissues of Fish from the Canal in Miamisburg, Ohio." Environ. Res. 17:228-235.

Kerfoot, E. J., W. G. Fredrick, and E. Domeier. 1975. "Cobalt Metal Inhalation Studies on Miniature Swine." Am. Ind. Hyg. Assoc. J. 36(1):17-25.

Kevern, N. R. 1966. "Feeding Rate of Carp Estimated by a Radioisotopic Method." Trans. Amer. Fish Soc. 25(4):363-371.

Kiem, J., G. V. Iyengar, H. Borberg, K. Kasperek, M. Siegers, L. E. Feinendegen, and R. Gross. 1979. "Sampling and Sample Preparation of Platelets for Trace Element Analysis and Determination of Certain Selected Bulk and Trace Elements in Normal Human Platelets by Means of Neutron Activation Analysis." In Nuclear Activation Techniques in the Life Sciences, pp. 143-164. International Atomic Energy Agency, Vienna, Austria.

Kimura, Y., and Y. Honda. 1977a. "Uptake and Elimination of Some Radionuclides by Eggs and Fry of Rainbow Trout (I)." J. Radiat. Res. 18:170-181.

Kimura, Y., and Y. Honda. 1977b. "Uptake and Elimination of Some Radionuclides by Eggs and Fry of Rainbow Trout (II)." J. Radiat. Res. 18:182-193

King, S. F. 1964. "Uptake and Transfer of Cesium-137 by Chlamydomonas, Daphnia, and Bluegill Fingerlings." Ecology 45:852-859.

Kirchmann, R., J. Remy, P. Charles, G. Koch, and J. Van den Hoek. 1973. "Distribution et Incorporation du Tritium dans les Organes de Ruminants." In Environmental Behaviour of Radionuclides Released in the Nuclear Industry, pp. 385-402. International Atomic Energy Agency, Vienna, Austria.

Kirchmann, R., P. Charles, R. Van Brawaene, J. Remy, G. Koch, and J. Van Den Hoek. 1977. "Distribution of Tritium in the Different Organs of Calves and Pigs after Ingestion of Various Tritiated Feeds." Curr. Topics Radiat. Tres. Quart. 12:291-312.

Klaverkamp, J. F., M. A. Tumer, S. E. Harrison, and R. H. Hesslein. 1983. "Fates of Metal Radiotracers Added to a Whole Lake: Accumulation in Slimy Sculpin (Cottus Cognatus) and White Sucker (Catostomus Commersoni). Sci. Total Environ. 28:119-128.

Klechkovskii, V. M. 1973. Radioecology. J. Wiley, Jerusalem

Klepper, B., L. E. Rogers, J. D. Hedlund, R. G. Schreckhise, and K. R. Price. 1978. "Radiocesium Movement in a Gray Rabbit Brush Community." In Environmental Chemistry and Cycling Processes. eds. D. C. Adriano and I. L. Brisbin, Jr., pp. 725-737. Proceedings of a Symposium held at Augusta, Georgia, April 28-May 1, 1976, CONF-760429, U.S. Department of Energy, Washington, D.C. 
Knepp, G. L., and G. F. Arkin. 1973. "Ammonia Toxicity Levels and Nitrate Tolerance of Channel Catfish." The Progressive Fish-Cultruist 35(4):221-224.

Kolehmainen, S. E., E. Hasanen, E., J. K. Miettinen. 1966. "137Cs Levels in Fish of Different Limological Types of Lakes in Finland During 1963." Health Phys. 12: 917.

Koranda, J. J., and J. R. Martin. 1973. "The Movement of Tritium in Ecological Systems." In Tritium, eds. A. A. Moghissi and M. W. Carter, pp. 462-470. Messenger Graphics, Phoenix, Arizona.

Koulikov, A. O., and I. N. Ryabov. 1992. "Specific Cesium Activity in Freshwater Fish and the Size Effect." Sci. Total Environ. 112:125-142.

Kovalsky, V. V., I. E. Voronitskaya, and V. S. Lakarev. 1967. Biogeochemical Food Chains of Uranium in Aquatic and Terraneous Organisms. Int. Symp. Radiol. Concent. Process., Stockholm, eds. P. Aberg and F. P. Hungate. Pergamon Press, Inc., Oxford, England.

Kovalsky, V. V., I. E. Vorotonitskaya, and V. S. Lekarev. 1966. "Biogeochemical Food Chains of Uranium in Aquatic and Terraneous Organisms." In Radioecological Concentration Processes, eds. B. Aberg and F. P. Hungate, pp. 329-332. Pergamon Press, Inc. Oxford, England.

Kramp, R. A., M. MacDowell, C. W. Gottschalk, J. R. Oliver, and M. MacDowell. 1968. "A Study by Microdissection and Micropunture of the Structure and the Function of the Kidneys and the Nephrons of Rats with Chronic Renal Damage." Kidney Int. 5:147-176.

Krivolutsky, D. A., T. L. Kozhevnikova, V. Z. Martjushov, and G. I. Antonenko. 1992. "Effects of Transuranic $\left({ }^{239} \mathrm{Pu},{ }^{239} \mathrm{~Np},{ }^{241} \mathrm{Am}\right)$ Elements on Soil Fauna." Biol. Fert. Soils 13:79-84.

Krumholz, L. A. 1954. A Summary of Findings of the Ecological Survey of White Cak Creek, Roane County, Tennessee, 1950-1953, Tennessee Valley Authority, Vol. III. ORO-587, USAEC, Oak Ridge, Tennessee.

Krumholz, L. A., and J. H. Rust. 1954. "Osteogenic Sarcoma in the Muskrat from an Area of High Environmental Radiostrontium." AMA Arch. Path. 57:270.

Krumholz, L. A., E. D. Goldberg, and H. Boroughs. 1957. "Ecological Factors Involved in the Uptake, Accumulation, and Loss of Radionuclides by Aquatic Organisms." Chapter 7 in Effects of Atomic Radiation on Oceanography and Fisheries. Publ. No. 551, Natl. Aca. Sci., Natl. Res. Council, Washington, D.C.

Kushniruk, V. A. 1964. "The Radiosensitivity of Birds." In Biological Effects of Radiation. No. 1, Laboratory of Radiobiological Problems. JPRS 23:169-171.

La Touche, Y. D., D. L. Willis, and O. I. Dawydiak. 1987. "Absorption and Biokinetics of U in Rats Following an Oral Administration of Uranyl Nitrate Solution." Health Phys. 53:147-162.

Laborda, R., J. Diaz-Mayens, and A. Nunez. 1986. "Nephrotoxic and Hepatotoxic Effects of Chromium Compounds in Rats." Bull. Environ. Contam. Toxicol. 36:332-336.

Lambrechts, A. 1984. Essai de Modélisation du Transfert du Césium 137 dans les Compartiments d'un Écosystéme d'eau Douce Simplifié. Thése d'Université, Univ. Aix-Mardeille I, Marseille, France, p. 181.

Lambrechts, A. and L. Foulquire. 1986. "Experimental Study on the Transfer of a Radionuclide Mixture Between Water, Sediment, and Fish." In Application of Distribution Coefficients of 
Landa, E. R., L. J. Hart Thorvig, and R. G. Gast. 1977. "Uptake and Distribution of Technetium-99 in Higher Plants." In Biological Implications of Metals in the Environment, pp. 390-401. Proceedings of the Fifteenth Annual Hanford Life Sciences Symposium at Richland, Washington, September 29-October 1, 1975. CONF-750959, U.S. Department of Energy, Washington, D.C.

Langard, S., and A. L. Nordhagen. 1980. "Small Animal Inhalation Chambers and the Significance of Dust Ingestion from the Contaminated Coat when Exposing Rats to Zinc Chromate." Acta. Pharmacol. Toxicol. 46:43-46.

Langard, S., and T. Norseth. 1986. "Chromium." In Handbook on Toxicology of Metals, Vol. 2, 2nd ed., eds. L. Frieberg, G. F. Nordberg, and B. B. Vouk, pp. 185-210. Elsevier Scientific, Amsterdam, The Netherlands.

Langham, W. 1959. "Physiology and Toxicology of Plutonium-239 and Its Industrial Medical Control." Health Phys. 2:172-185.

Larsen, R., R. Oldham, M. Bhattacharyya, E. S. Moretti, and D. J. Austin. 1981. "Plutonium Retention in Mice and Rats After Gastrointestinal Absorption." Radiat. Res. 87:37-49.

Larson, K. H., J. L. Leitch, W. F. Dunn, J. W. Neel, J. H. Olafson, E. E. Held, J. Taylor, W. J. Cross, and A. W. Bellamy. 1951. Alpha Activity Due to the 1945 Atomic Bomb Detonation at Trinity, Alamogordo, New Mexico. UCLA-108, University of California, Los Angeles, Califomia.

Larson, K. H., H. A. Hawthome, and J. H. Olafson. 1962. Nevada Test Site Fallout: Some Characteristics, Its Apparent Environmental Equilibrium and Biological Availability. University of California Report Number TID-7632, p. 4-24. University of Califomia, Los Angeles, California.

Laskey, J. W., J. L. Parrish, and D. F. Cahill. 1973. "Some Effects of Lifetime Parental Exposure to Low Levels of Tritium on the $\mathrm{F}_{2}$ Generation." Radiat. Res. 56:171-179.

Laskin, S., M. Kuschner, and R. T. Dew. 1969. "Studies in Pulmonary Carcinogenesis." In Inhalation Carcinogenesis, eds. M. G. Hanna, P. Nettesheim, and J. R. Gibert, pp. 321-351. U.S. Atomic Energy Commission, Oak Ridge, Tennessee.

Leach, L. J., E. A. Maynard, H. C. Hodge, J. K. Scott, C. L. Yuile, G. E. Sylvester, and H. B. Wilson. 1970. "A Five-Year Inhalation Study with Natural Uranium Dioxide $\left(\mathrm{UO}_{2}\right)$ Dust. I. Retention and Biologic Effects in the Monkey, Dog and Rat." Health Phys. 18:599-612.

Leach, L. J, C. J. Yuile, and H. C. Hodge. 1973. "A Five-Year Inhalation Study with Natural Uranium Dioxide $\left(\mathrm{UO}_{2}\right)$ Dust. II. Postexposure Retention and Biologic Effects in the Monkey, Dog, and Rat." Health Phys. 25:239-258.

Leach, L. J., R. M. Gelein, B. J. Panner, C. L. Yuile, C. C. Cox, M. M. Balys, and P. M. Rolchigo. 1984. The Acute Toxicity of the Hydrolysis Products of Uranium Hexafluoride when Inhaled by the Rate and Guinea Pig. K/SUB/81-9039/3, U.S. Department of Energy, Washington, D.C.

Leitch, J. L. 1951. Summary of the Radiological Findings in Animals from the Biological Surveys of 1947, 1948, 1949 and 1950. UCLA-111, University of California, Los Angeles, California.

Leonard, A. G. B. Gerber, P. Jacquet, R. R. Lauwerys. 1984. "Mutagenicity, Carcinogenicity, and Teratogenicity of Industrially Used Metals." In Mutagenicity, Carcinogenicity, and Teratogenicity of Industrial Pollutants, ed. M. Kirsch-Volders. Plenum Press, New York.

Leonard, A., and R. R. Lauwerys. 1980. "Carcinogencity and Mutagenicity of Chromium." Mutat. Res. 76:227-239. 
Leonard, A., and R. R. Lauwerys. 1980. "Carcinogencity and Mutagenicity of Chromium." Mutat. Res. 76:227-239.

Levis, A. G., and V. Bianchi. 1982. "Mutagenic and Cytogenic Effects of Chromium Compounds." In Biological and Environmental Aspects of Chromium, ed. S. Langard, pp. 171-208. Elsevier Applied Science Publ., Amsterdam, The Netherlands.

Lewis, R. J., Sr. 1992. SZX's Dangerous Properties of Industrial Materials, Eighth Edition. Van Nostrand Reinhold, New York.

Lewis, R. J., and R. L. Tatken (eds.). 1979-1980. Registry of Toxic Effects of Chemical Substances. U.S. Public Health Service, NIOSH, Cincinnati, Ohio.

Lippman, M., L. D. Y. Ong, and W. B. Harris. 1964. "The Significance of Urine Uranium Excretion Data." Ind. Hyg. J. Jan-Feb:43-54.

Llobet, J. M., J. J. Sirvent, A. Ortega, and J. L. Domingo. 1991. "Influence of Chronic Exposure to Uranium on Male Reproduction in Mice." Fund. Appl. Toxicol. 16:821-829.

Lofts, B., and J. Rotblat. 1962. "The Effects of Whole-Body Irradiation on the Reproductive Rhythm of the Avian Testis." Int. J. Radiat. Biol. 4(3):217-230.

Lowe, V. P. W. 1991. "Radionuclides and the Birds at Ravenglass." Environ. Poll. 70:1-26.

Lowe, V. P. W., and A. D. Horrill. 1991. "Caesium Concentration Factors in Wild Herbivores and the Fox (Vulpes vulpes L)." Environ. Poll. 770:93-107.

Lowman, F. G. 1970. "Preliminary Report on the Birds of the Gulf of Panama July 17, 1967 to August 15, 1967 in Bioenvironmental Radiological Safety Feasibility Studies Atlantic-Pacific Interoceanic Canal." Estuarine and Marine Ecology, Vol. IV, Appendix M. BMI-171-32, Battelle Memorial Institute, Richland, Washington.

Luckey, T. D., A. Kotb, J. R. Bogt, and D. P. Hutcheson. 1975. "Feasibility Studies in Rats Fed Heavy Metals as Multiple Nutrient Markers." J. Nutr. 109:660-669.

Lundgren, D. L., F. F. Hahn, A. H. Rebar, and R. O. McClellan. 1983. "Effects of the Single or Repeated Inhalation Exposure of Syrian Hamsters to Aerosols of Plutonium-239 Dioxide." Int. J. Radiat. Biol. Relat. Stud. Phys. Chem. Med. 43:1-18

Lundgren, D. L., N. A. Fillett, F. F. Hahn, W. C. Griffith, and R. O. McClellan. 1987. "Effects of Protraction of the Alpha Dose to the Lungs of Mice by Repeated Inhalation Exposure to Aerosols of Plutonium-239 Oxide." Radiat. Res. 111:201-224.

Lüning, K., H. Frolen, and A. Nilsson. 1976a. "Dominant Lethal Tests of Male Mice Given ${ }^{239} \mathrm{Pu}$ Salt Injections." In Biological and Environmental Effects of Low-Level Radiation, Vol. 1. pp. 39-49. International Atomic Energy Agency, Vienna, Austria.

Lüning, K., H. Frolen, and A. Nilsson. 1976b. "Genetic Effects of ${ }^{239} \mathrm{Pu}$ Salt Injections in Male Mice." Mutat. Res. 34:539-542.

MacKensie, R. D., R. U. Brerrum, G. F. Decker, C. A. Hoppert, and R. F. Laugham. 1958. "Chronic Toxicity Studies. II. Hexavalent and Trivalent Chromium Administered in Drinking Water to Rats." AMA Arch. Ind. Health 18:232-234.

MacKensie, R. D., R. A. Anwar, R. U. Byerrum, and C. A. Hoppert. 1959. "Absorption and Distribution of ${ }^{51} \mathrm{Cr}$ in the Albino Rat." Arch. Biochem. Biophysics 79:200-205 
Mahon, D. C. 1982. "Uptake and Translocation of Naturally-Occurring Radionuclides of the Uranium Series." Bull. Environ. Contam. Toxicol. 29:697-703.

Maienthal, E. J., and J. K. Taylor. 1968. "Polarographic Methods in Determination of Trace Inorganics in Water." In Trace Inorganic in Water. Advances in Chemistry Series No. 73, American Chemical Society, Washington, D.C.

Majone, F., and A. G. Levis. 1978. "Chromosomal Aberrations and Sister Chromatid Exchange in CHO Treated with Cr(VI)." Mutat. Res. 67:231-238.

Major, R. H. 1922. "Studies on a Case of Chromic Acid Nephritis." Johns Hopkins Hosp. Bull. 33:56-61.

Malenchenko, A. F., N. A. Barkun, and G. F. Guseva. 1978. "Effect of Uranium on the Induction and Course of Experimental Autoimmune Orchitis and Thyroiditus." J. Hyg. Epidemiol., Microbiol., and Immunol. 22:268-277.

Mancuso, T. F., and W. C. Hueper. 1951. "Occupational Cancer and Other Health Hazards in a Chromate Plant: A Medical Appraisal. I. Lung Cancers in Chromate Workers." Ind. Med. Surg. 20:358-363.

Mangi, J., K. Schmidt, J. Pankow, L. Gaines, and P. Turner. 1978. "Effects of Chromium on Some Aquatic Plants." Environ. Pollut. 16(4):285-291.

Martin, J. R., and J. J. Koranda. 1972. "Biological Half-Life Studies of Tritium in Chronically Exposed Kangaroo Rats." Radiat. Res. 50:426-440.

Marzilli, L. G. 1981. "Metal Complexes of Nucleic Acid Derivatives and Nucleotides: Binding Sites and Structures." In Advances in Inorganic Biochemistry, Vol. III, pp. 47-87. Elsevier, New York.

Maslov, V. I., K. I. Maslova, and I. N. Verkhovskaya. 1967. "Characteristics of the Radioecological Groups of Mammals and Birds of Biogeocoenoses with High Natural Radiation." In Radioecological Concentration Processes, eds. B. Aberg and F. P. Hungate, p. 561. Pergamon Press, London, England.

Masson, M. F. Patti, Cl Colle, P. Roucoux, A. Grauby, and A. Saas. 1989. "Synopsis of French Experimental and In Situ Research on the Terrestrial and Marine Behavior of Tc." Health Phys. 57:269-279.

Mathur, A. K., S. V. Chandra, and S. K. Tandon. 1977. "Comparative Toxicity of Trivalent and Hexavalent Chromium in Rabbits. III. Morphological Changes in Some Organs." Toxicology 8:53-61.

Matsumuto, N. S., S. Iijima, and H. Katsunuma. 1976. "Placental Transfer of Chromic Chloride and Its Teratogenic Potential in Embryonic Mice." J. Toxicol. Sci. 2:1-13.

Maynard, E. A, and H. C. Hodge. 1949. "Studies of the Toxicology of Various Uranium Compounds when Fed to Experimental Animals." In Pharmacology and Toxicology of Uranium Compounds, National Nuclear Energy Series (VI), pp. 309-376, eds. I. C. Voegtlin and H. C. Hodge. McGraw-Hill Book Company, New York.

Maynard, E. A., W. L. Downs, and H. C. Hodge. 1953. "Oral Toxicity of Uranium Compounds." In Pharmacology and Toxicology of Uranium Compounds, eds. I. C. Voegtlin and H. C. Hodge. McGraw-Hill Book Company, New York. 
Mays, C. W., and R. D. Lloyd. 1972. "Bone Sarcoma Incidence vs. Alpha Particle Dose." In The Radiobiology of Plutonium, eds, B. J. Stover, and W. S. S. Jee, pp. 409-430. J. W. Press, Salt Lake City, Utah.

Mays, C. W., R. E. Rowland, and A. F. Stehney. 1985. "Cancer Risk from the Lifetime Intake of Ra and U Isotopes." Health Phys. 48:635-647.

McGill, P. E., M. G. Harden, J. W. K. Robertson, and J. Shimmins. 1971. "A Comparison Between the Uptake of Technetium-99m and Iodine-131 by the Thyroid Gland." J. Endocrinol. 49:531-536.

McKee, J. E., and H. W. Wolf. 1963. Water Quality Criteria. No. 3-A, Resources Agency of Califomia, State Water Resources Control Board, Sacramento, California.

McMurtry, J. E., and W. O. Robinson. 1938. "Neglected Soil Constituents that Affect Plant and Animal Development." U.S. Dept. Agric. Yearbook. U.S. Department of Agriculture, Washington, D.C.

Mellinger, P. J., and V. Schultz. 1975. "Ionizing Radiation and Wild Birds: A Review." CRC Crit. Rev. Environ. Contr. 397-421.

Menzel, R. G. 1963. "Factors Influencing the Biological Availability of Radionuclides for Plants." Federation Proc. 22:1398-1401.

Menzer, R. E. 1991. "Water and Soil Pollutants." In Casarett and Doulls Toxicology, The Basic Science of Poisons, 4th edition, eds. M. O. Amdur, J. Doulls, and C. D. Klaassen, pp. 872-902. Pergamon Press, Inc., New York.

Mertz, W. 1975. "Effects and Metabolism of Glucose Tolerance Factor." Nutr. Rev. 33:129-135.

Mertz, W., and E. E. Roginsky. 1975. "Some Biological Properties of Chromium (Cr) Nicotinic Acid (NA) Complexes." Fed. Proc. 34:922.

Métivier, H., R. Masse, J. Wahrendorf, and J. LaFuma. 1986. "Combined Effects of Inhaled Plutonium Oxide and Benzo(a)pyrene on Lung Carcinogenesis in Rats." In Life-Span Radiation Effects Studies in Animals: What Can They Tell Us? Proceedings from the 22nd Hanford Life Sciences Symposium, Richland, Washington, eds. R. Thompson and J. Mahaffey. DE87000490, National Technical Information Service, Springfield, Virginia.

Mewhinney, J., H. Gillett, and B. Muggenburg. 1987. "Toxicology of ${ }^{238} \mathrm{PuO}_{2}$ in Beagle Dogs: A. Monodisperse 1.5- $\mu$ AMAD Particles. B. Monodisperse 3.0- $\mu \mathrm{m}$ AMAD Particles." Annual Report to U.S. Department of Energy, Washington, D.C. LMF-115, Inhalation Toxicology Research Institute, Albuquerque, New Mexico.

Moffett, D., and M. Tellier. 1977. "Uptake of Radioisotopes by Vegetation Growing on Uranium Tailings." Can. J. Soil Sci. 57:417-424.

Moghissi, A. A., E. W. Bretthauer, and R. G. Patzer. 1987. "Biological Concentration of 3-H. No Preference for 3-H in Biological Systems." Health Phys. 53:385-388.

Mogilevshaya, O. Y., and N. T. Raikhlin. 1963. "Rare-Earth Metals." In Toxicology of Rare Metals, ed. Z. I. Izraelson, pp. 609-613. Gusudarstyennoe Izdatelstvo Meditsinskoi Literatury, Moscow, Russia.

Moores, S., R. Talbot, N. Evans, B. E. Lambert. 1986. "Macrophage Depletion of Mouse Lung Following Inhalation of Plutonium-239 Dioxide." Radiat. Res. 105:387-404. 
Morin, M., J. Nenot, and J. Lafuma. 1972. "Metabolic and Therapeutic Study Following Administration to Rats of ${ }^{238} \mathrm{Pu}$ Nitrate--A Comparison with ${ }^{239} \mathrm{Pu}$." Health Phys. 23:475-480.

Morris, J, and L. Winn. 1978. "Effects of Inhaled ${ }^{239} \mathrm{PuO}_{2}$ on the Primary Immune Response of Beagle Dogs. Part I. Biomedical Sciences." 1977 Annual Report to U.S. Department of Energy, Washington, D.C. PNL-2500, Pacific Northwest Laboratory, Richland, Washington.

Morrow, P. E., L. J. Leach, F. A. Smith, R. M. Gelein, J. M. Scott, H. D. Beiter, F. J. Amato, J. J. Picano, C. L. Yuile, and T. G. Consler. 1981. Metabolic Fate and Evaluation of Injury in Rats and Dogs Following Exposure to the Hydrolysis Products of Uranium Hexafluoride. NUREG/CR-2268, U.S. Nuclear Regulatory Commission, Washington, D.C.

Morrow, P., R. Gelein, H. Beiter, J. Scott, J. Picano, and C. Yuile. 1982. "Inhalation and Intravenous Studies of UF6/UO2F2 in Dogs." Health Phys. 43:859-873.

Mousney, J. M, and C. Myttenaere. 1981. "Absorption of Technetium by Plants in Relation to Soil Type, Contamination Level and Time." Plant Soil 61:403-412.

Mraz, F. R. 1971. "Effects of Continuous Gamma-Irradiation of Chick Embryos upon Their Gonadal Development." Radiat. Res. 48:164-168.

Muggenburg, B. A., R. Wolff, J. C. Mauderly, M. M. Plaggmier, and R. F. Gerlach. 1986. "Cardiopulmonary Function of Dogs with Plutonium-Induced Chronic Lung Injury." Annual Report to U.S. Department of Energy, Washington, D.C. In Inhalation Toxicology Research Institute Annual Report 1985-1986, pp. 251256. LMF-115, Inhalation Toxicology Research Institute, Albuquerque, New Mexico.

Muggenburg, B. A., R. A. Guilmette, F. F. Hahn, B. B. Boecker, and R. D. McClellan. 1987. "Toxicity of Inhaled ${ }^{239} \mathrm{PuO}_{2}$ in Beagle Dogs. A. Monodisperse $0.75 \mu \mathrm{m}$ AMAD Particles. B. Monodisperse 1.5 $\mu \mathrm{m}$ AMAD Particles." Annual Report to U.S. Department of Energy, Washington, D.C. LMF-120, Inhalation Toxicology Research Institute, Albuquerque, New Mexico, pp. 248-259.

Muller, H. D., and R. E. Morenz. 1966. "Growth and Reproductive Potential of the Domestic Foul After Embryonic X-Radiation." Poult. Sci. 45:336-345.

Murdock, H. R. 1953. "Industrial Wastes: Some Data on Toxicity of Metals in Wastes to Fish Life are Presented." Ind. Eng. Chem. 45:99A.

Murthy, T. C. S., P. Weinberger, and M. P. Measures. 1984. "Uranium Effects on the Growth of Soybean (Glycine max (L.) Merr.)." Bull. Environ. Contam. Toxicol. 32:580-586.

Murti, R., R. Omka , and G. S. Shukla. 1983. "Chromium Toxicity to a Fresh Water Prawn Macrobrahium Lammarrei." Toxicology Lett. (AMST) 18(3):257-262.

Myers, D. K. 1989. The General Principles and Consequences of Environmental Radiation Exposure in Relation to Canada's Nuclear Fuel Waste Management Concept. AECL 9917, Atomic Energy of Canada Limited, Chalk River Nuclear Laboratories, Chalk River, Ontario, Canada.

Nakajima, A., T. Horiskoshi, and T. Sakaguchi. 1979. "Ion Effects on the Uptake of Uranium by Chlorella regularis." Agric. Biol. Chem. 43(3):625-629.

Nakamuro, K., K. Yoshikawa, Y. Sayato, and H. Kurata. 1978. "Comparative Studies of Chromosomal Aberration and Mutagenicity of Trivalent and Hexavalent Chromium." Mutat. Res. 58:175-181. 
NAS. 1974. "Medical and Biologic Effects of Environmental Pollutants." Chromium. National Academy Press, Washington, D.C.

National Institute for Occupational Safety and Health (NIOSH). 1987. Registry of Toxic Effects of Chemical Substances. U. S. Department of Health and Human Services, Public Health Service, Washington D.C.

National Research Council of Canada (NRCC). 1982. Data Sheets on Selected Toxic Elements. 19252, National Research Council, Ottawa, Canada.

Neel, J. W., and M. A. Onasch. 1989. "Cytological Effects of Tc on Young Soybean Plants." Health Phys. 57:289-298.

Neff, J. M., R. S. Foster, and J. F. Slowey. 1978. Availability of Sediment-Sorbed Heavy Metals to Benthos with Particular Emphasis on Deposit-Feeding Infauna. Tech. Rep. 0-78-42. U.S. Army Waterways Exp. Sta., Vicksburg, Mississippi.

Nelson, D. J., N. R. Kevern, and N. A. Griffith. 1967. "Cesium and Potassium in Aquatic Food Chains," pp. 97-98. In Health Phys. Div. Ann. Progr. Rept., ORNL-4168, Oak Ridge National Laboratories, Oak Ridge, Tennessee.

Nelson, S., C. Chen, A. Tsai, and I. A. Dyer. 1973. "Effect of Chelating Agents on Chromium Absorption in Rats." J. Nutr. 103:1182-1186.

Nettesheim, P., and A. S. Hammons. 1971. "Induction of Squamous Cell Carcinoma in the Respiratory Tract of Mice." J. Natl. Cancer. Inst. 47:697-701.

Ng, Y. C., C. S. Colsher, and S. E. Thomspon. 1982. Soil to Plant Concentration Factors for Radiological Assessments. NUREG/CR-2975, UCID-19463, Lawrence Livermore Laboratory, Livermore, California.

Norris, R. A. 1958. "Some Effects of X-Irradiation on the Breeding Biology of Eastem Bluebirds." Auk 75:444-455.

Norris, W. P., C. M. Poole, and C. E. Rehfeld. 1966. Cesium-137: Current Status and Late Effects. USAEC Report ANL-7278, Washington, D.C.

Norseth, T., 1981. "The Carcinogenicity of Chromium." Environ. Health Perspect. 40:121-130.

Noshkin, V. E., V. T. Bowen, K. M. Wong, and J. C. Burke. 1973. Plutonium in North Atlantic Ocean Organisms. Ecological Relationships. In Radionuclides in Ecosystems, Vol. 2. USAEC Report CONF-710501, National Technical Information Service, Springfield, Virginia.

Novikov, U. V., and T. V. Yudina. 1970. "Data on the Biological Effects of Small Amounts of Natural Uranium in Water." Gig. Sanit. 35(1):63-75. Cited from Guidelines for Surface Water Qtaality, Vol. 1, Inorganic Chemical Substances. 1983 Environment Canada, Inland Waters Directorate, Water Quality Branch, Ottawa, Canada.

Nuclear Energy Agency (NEA). 1981. The Environmental and Biological Behaviour of Plutonium and Some Other Transuranium Elements. Nuclear Energy Agency, OECD, Paris, France.

O'Farrel, T. P. 1969. "Effects of Aute Ionizing Radiation in Selected Pacific Northwest Rodents." In Symposium on Radioecology, eds. D. J. Nelson and F. C. Evans, pp. 157-165. CONF-670503, CFSTI, National Bureau of Standards, Springfield, Virginia. 
Oakenberg, E. F., and E. Clark. 1964. Effects of lonizing Radiation on the Reproductive System, eds. W. D. Carison, and F. X. Gassner, p. 11. Pergamon Press, Inc., New' York.

Odum, E. P. 1956. "Ecological Aspects of Waste Disposal." In Proceedings from a Conference on Radioactive Isotopes in Agriculture. TID-7512, USAEC, Technical Information Center, Springfield, Virginia.

Ogawa, R. 1976. "Experimental Study on Absorption, Distribution, and Excretion of Trivalent and Hexavalent Chromes." Jpn. J. Pharmacol. 26:92.

Olafson, J. H., H. Nashita, K. H. Larson. 1957. The Distribution of Plutonium in the Soils of Central and Northeastern New Mexico as a Result of the Atomic Bomb Test of July 16, 1945. USAEC Report UCLA-406, University of California, Los Angeles, California.

Ontario Water Resources Commission (OWRC). 1971. Water Pollution from the Uranium Mining Industry in the Elliot Lake-Bancroft Areas. Vol. I and Vol. II. Ministry of the Environment, Sudbury, Ontario, Canada.

Orcutt, J. A. 1949. "The Toxicology of Compounds of Uranium Following Application to the Skin." In Pharmacology and Toxicology of Uranium Compounds, eds. I. C. Voegtlin and H. C. Hodge, pp. 377-414. McGraw-Hill Book Company, New York.

Osborme, R. V. 1972. "Permissible Levels of Tritium in Man and the Environment." Radiat. Res. 50:197-211.

Osburn, W. S., Jr. 1968. "Forecasting Long-Range Recovery from Nuclear Attack." In Proceedings from Postattack Recovery from Nuclear War Symposium, p. 107. National Academy of Sciences, National Academy of Engineering, National Research Council, Washington, D.C.

Packard, C. 1936. "Biological Effectiveness of X-Ray Wavelength." Chapter 13 in Biological Effects of Radiation, ed. B. M. Duggar. McGraw-Hill Book Company, New York.

Paine, D. 1980. "Plutonium ion Rocky Flats Freshwater Systems." In Transuranic Elements in the Environment, ed. W. Hanson, pp. 644-658. DOE/TIC-22800, National Technical Information Service, Springfield, Virginia.

Park, J., W. Bair, and R. Busch. 1972. "Progress in Beagle Dog Studies with Transuranium Elements at Battelle-Northwest." Health Phys. 22:803-810.

Park, J., R. Buschbom, and G. Dagle. 1988. "Inhaled Plutonium Oxide in Dogs. Part 1. Biomedical Sciences, 1987." Annual Report to U.S. Department of Energy, Office of Energy Research. PNL-6500, Pacific Northwest Laboratory, Richland, Washington.

Parkhurst, B. R., R. W. Pennak, and W. T. Waller. 1984. "An Environmental Hazard Evaluation of Uranium in a Rocky Mountain Stream." Environ. Toxicol. Chem. 3:113-124.

Paternain, J. L, J. L. Domingo, A. Ortega, and J. M. Llobet. 1989. "The Effects of Uranium on Reproduction, Gestation, and Postnatal Survival in Mice." Ecotox. Environ. Saf. 17:291-296.

Pelton, M. R. and E. E. Provost. 1969. "Effects of Radiation on Survival of Wild Cotton Rats (Sigmodon hispidus) in Enclosed Areas of Natural Habitat." In Sym $m_{i}$ osium on Radioecology, eds. D. J. Nelson and F. C. Evans, pp. 39-45. CONF-670503, CFSTI, National Bureau of Standards, Springfield, Virginia. 
Pendleton, R. C., and W. C. Hanson. 1958. Absorption of Cesium-137 by Components of an Aquatic Community. Proceedings of the 2nd International Conference on Peaceful Uses of Atomic Energy 18:419-422.

Pendleton, R. C., R. D. Lloyd, C. W. Mays, and B. N. Church. 1964. "Trophic Level Etfect on the Accumulation of Caesium-137 in Cougars Feeding on Mule Deer." Nature 204:708-709.

Perlowagora-Szumlewicz, A. 1964. "Effect of Ionizing Radiation on the Population Kinetics of the Snail Australorbis glabratus: Age at Exposure and the Effects on Reproduction." Radiat. Res. 23:392-404.

Peterman, B. F. 1982. "Computer Modelling of HT Gas Metabolism in Humans." Rad. Prot. Dos. 3:129-133.

Peterman, B. F., J. R. Johnson, and R. G. C. McElroy. 1985. "HT/HTO Conversion in Mammals." Fusion Technol. 8: 2557-2463.

Phillips, L. J. 1986. Could Radiation have been Responsible for the Disappearance of BlackHeaded Gulls from the Ravenglass Estuary? MS thesis, University of London, England.

Phillips, L. J., and J. E. Coggle. 1988. "The Radiosensitivity of Embryos of Domestic Chickens and Black-Headed Gulls." Int. J. Radiat. Biol. 53:309-317.

Pickering, Q. H., and C. Henderson. 1966. "The Acute Toxicity of Some Heavy Metals to Different Species of Warm Water Fishes." Int. J. Air Water Pollu. 10:453-463.

Pietrzak-Flis, Z. I. Radwan, Z. Major, and M. Kowalska. 1982. "Tritium Incorporation in Rats Chronically Exposed to Tritiated Water for Three Successive Generations." Radiat. Res. 22:434-442.

Pietrzak-Flis, Z., I. Radwan, and L. Indeka. 1978. "Tritium in Rabbits After Ingestion of FreezeDried Tritiated Food and Tritiated Water." Radiat. Res. 76:420-428.

Pinson, E. A., and W. H. Langham. 1957. "Physiology and Toxicology of Tritium in Man." J. Appl. Physiol. 10:108-126.

Pizzarello, D. J. 1973. Radiation Biology. CRC Press, Miami, Florida.

Platt, R. B. 1965. "Radiation Effects on Plant Populations and Communities: Research Status and Potential." Health Phys. 11:1601-1606.

Polar, E., and N. Bayulgen. 1991. "Differences in the Availabilities of Cesium-134, 137 and Ruthenium-106 from a Chemobyl-Contaminated Soil to a Water Plant, Duckweed, and to the Terrestrial Plants, Bean and Lettuce." J. Envrion. Radioactivity 13:251-259.

Poston, T. M. 1982. "Observations on the Bioaccumulation Potential of Thorium and Uranium in Rainbow Trout (Salmo gairdneri). Bull. Environ. Contam. Toxicol. 28:682-690.

Poston, T. M., and D. C. Klopfer. 1985. A Literature Review of the Concentration Factors of Selected Radionuclides in Freshwater and Marine Fish. PNL-5484, Pacific Northwest Laboratory, Richland, Washington.

Poston, T. M., R. W. Hanf, Jr., and M. A. Simmons. 1984. "Toxicity of Uranium to Daphnia magna." Water, Air, Soil Pollution 22:289-298.

Powers, E. B. 1971. "The Goldfish (Carassius aurtus) as a Test Animal in the Study of Toxicity." Ill. Biol. Monogr. 4:127-193. 
Preston, A. M., R. P. Dowdy, M. A. Preston, and J. N. Freeman. 1976. "Effect of Dietary Chromium on Glucose Tolerance and Serum Cholesterol in Guinea Pigs." J. Nutr. 106:1391-1397.

Pribil, S. and P. Marvan. 1976. "Accumulation of Uranium by the Chlorococcal Alga Scenedesmus quadricauda." Arch. Hydrobiol. Supplement B 49(2):214-225.

Price, K. R. 1972. Uptake of Np-237, Pu-239, Am-241 and Cm-244 from Soil by Tumbleweed and Cheatgrass. BNWL-1688, Battelle, Pacific Northwest Laboratories, Richland, Washington.

Priest, N. D., G. R. Howells, D. Green, and J. W. Haines. 1982. "Uranium in Bone: Metabolic and Autoradiographic Studies in the Rat." Human Toxicol. 1:97-114.

Ragan, H., R. Buschbom, J. Park, G. E. Dagle, and R. E. Weller,. 1986. "Hematologic Effects of Inhaled Plutonium in Beagles." In Life-Span Radiation Effects Studies in Animals: What Can They Tell Us?, eds. R. Thompson and J. Mahaffey. Proceedings from the 22nd Hanford Life Sciences Symposium, Richland, Washington, pp. 447-487. DE87000490, National Technical Information Service, Springfield, Virginia.

Reeder, S. W. 1979. Guidelines for Surface Water Quality. Vol. 1. Inorganic Chemical Substances. Preamble, Inland Waters Directorate, Water Quality Branch, Environment Canada, Ottawa, Canada.

Reichle, D. E., and D. A. Crossley, Jr. 1969. "Trophic Level Concentrations of Cesium-137, Sodium, and Potassium in Forest Arthropods." In Proceedings of the Ecological Society of America's Second National Symposium on Radioecology, eds. D. J. Nelson and F. C. Evans, pp. 678-686, Ann Arbor, Michigan May 15-17, 1967, CONF-670503, USAEC, Washington, DC.

Reichle, D. E., M. H. Shanks, and D. A. Crossley, Jr. 1969. "Calcium, Potassium, and Sodium Content of Forest Floor Arthropods." Ann. Entomol. Soc. Amer. 62:57-62.

Reichle, D. E., P. B. Dunaway, D. J. Nelson. 1970a. "Turnover and Concentration of Radionuclides in Foud Chains." Nuclear Safety 11:43-55.

Reichle, D. E., D. J. Nelson, and P. B. Dunaway. 1970b. Biological Concentration and Turnover of Radionuclides in Food Chains. ORNL-TM-2492, Oak Ridge National Laboratory, Oak Ridge, Tennessee.

Relman, A. S. 1957. "The Physiological Behavior of Rubidium and Cesium in Relation to that of Potassium." Yale J. Biol. Med. 29:248-262.

Rickard, W. H., and H. A. Sweany. 1977. "Radionuclides in Canada Goose Eggs." In Biological Implications of Metals in the Environment, pp. 623-627. Proceedings of the Fifteenth Annual Hanford Life Sciences Symposium at Richland, Washington, September 29-October 1, 1975. CONF-750929, U.S. Department of Energy, Washington, D.C.

Rickard, W. H., R. E. Fitzner, and C. E. Cushing. 1981. "Biological Colonization of an Industrial Pond: Status After Two Decades." Environ. Conserv. 8:241-247.

Ridder, W. E., and F. W. Oeheme. 1974. "Nitrates as an Environmental, Animal, and Human Hazard." Clin. Toxicol. 7:145.

Ridgeway, L. P., and D. A. Karnofsky. 1952. "The Effects of Metals on the Chick Embryo. Toxicity and Production of Abnormalities in Development." Ann. NY Acad. Sci. 55:203-215.

Robards, A. W., and M. E. Robb. 1972. "Uptake and Binding of Uranyl Ions by Barley Roots." Science 178:980-982. 
Robinson, A. V. , T. R. Garland, G. S. Schneiderman, R. E. Wildung, and H. Drucker. 1977. In Biological Implications of Metals in the Environment, pp. 52-62. Proceedings of the Fifteenth Annual Hanford Life Sciences Symposium at Richland, Washington, September 29-October 1, 1975. CONF-750929, U.S. Department of Energy, Washington, D.C.

Robinson, W. O., H. Bastron, and K. J. Murata. 1958. "Biogeochemistry of the Rare-Earth Elements with Particular Reference to Hickory Trees." Geochim. Cosmochim. Acta 14:55-67.

Roche, J., R. Michel, E. Volpert, and B. Sanz. 1957. "Sur la Fixation du Manganese et du Rhebinium Radioactifs par le Corps Thyroide et les Oocytes de la Poule Pondeuse." C. R. Soc. Biol. 151:1098-1100.

Roderick, T. H. (ed.). 1964. "The Effects of Radiation on the Heredity Fitness of Mammalian Populations." Genetics 50(Suppl.):1023.

Romney, E. M., and J. J. Davis. 1972. "Ecological Aspects of Plutonium Dissemination in Terrestrial Environments." Health Phys. 22:551-257.

Romney, E. M., H. M. Mock, and K. H. Larson. 1970. "Persistence of Plutonium in Soil, Plants, and Small Mammals." Health Phys. 19:487-491.

Romney, E. M., E. H. Essington, E. B. Fowler, T. Tamura, and R. O. Gilberts. 1979. "Plutonium in the Desert Environment of the Nevada Test Site and the Tonopah Test Range." In Environmental Research on Actinide Elements, eds. J. E. Pinder, J. J. Alberts, K. W. McLeod, R. G. Schreckhise, pp. 121-130. Proceedings of a Symposium Held at Hilton Head, South Carolina, November 7-11, 1983. CONF-841142, U.S. Department of Energy, Washington, D.C.

Rosenthal, H., J. E. Gilster, and J. T. Bird. 1963. "Strontium-90 Content of Deciduous Human Incisors." Science 140:176-177.

Rosomer, G. L., W. A. Dudley, L. J. Machlin, and L. Loveless. 1961. "Toxicity of Vanadium and Chromium for the Growing Chick." Poult. Sci.40:1171-1173.

Routson, R. C., and D. A. Cataldo. 1977. Tumbleweed and Cheatgrass Uptake of ${ }^{99}$ Tc from Five Hanford Project Soils. BNWL-2183, Battelle, Pacific Northwest Laboratories, Richland, Washington.

Roucoux, P., and C. Colle. 1986. "Retention par les Vegetaux du Technetium Relache dans 1'Environnement en Association avec d'Autres Radiopolluants." In: Technetium in the Environment. (CEA-IPSN, Saint Paul-lez-Durance, .France), Elsevier Applied Science Publ., London and New York.

Rowland, R. E., A. F. Stehney, and H. F. Lucas. 1978. "Dose-Response Relationships for Female Radium Dial Workers." Radiat. Res. 76:368-383.

Ruggles, R. G., D. J. Robinson, and A. Zaidi. 1979. A Study of Water Pollution in the Vicinity of Two Abandoned Uranium Mills in Northern Saskatchewan. Northwest Region, EPS, Environment Canada, EPS 5-NW-79-6.

Rugh, R. 1964. Effects of Ionizing Radiation on the Reproductive System, eds. W. D. Carlson, and F. X. Gassner, p. 25. Pergamon Press, Inc., New York.

Rust, J. H., B. F. Trum, and U. S. G. Kuhn, III. 1954. "Physiological Aberrations Following Total Body Irradiation of Domestic Animals with Large Doses of Gamma Rays." Vet. Med. 49:318. 
Salo. A. A. Alha, and J. K. Miettinen. 1963. "Caesium-137 in the Blood of the Finnish Lapps." Nature 200:1119-1120.

Samitz, M. H., J. Schrager, and S. Katz. 1962. "Studies on the Prevention of Injurious Effects on Chromates in Industry." Ind. Med. Surg. 31:427-432.

Sanders, C. L. 1977 . "Inhalation Toxicology of ${ }^{238} \mathrm{PuO}_{2}$ and ${ }^{239} \mathrm{PuO}_{2}$ in Syrian Golden Hamsters." Radiat. Res. 70:344-344.

Sanders, C. L. 1978. "Effects of Repeated Exposures to ${ }^{239} \mathrm{PuO}_{2}$." Part 1. Biomedical Sciences. 1977 Annual Report to U.S. Department of Energy, Washington, D.C. PNL-2500, Pacific Northwest Laboratory, Richland, Washington.

Sanders, C. L., and J. Mahaffey. 1981. "Inhalation Carcinogenesis of Repeated Exposures to HighFired ${ }^{239} \mathrm{PuO}_{2}$ in Rats." Health Phys. 41:629-644.

Sanders, C. L., G. Dagle, W. Cannon, G. I. Powers, and D. M. Meier. 1977. "Inhalation Carcinogenesis of High-Fired Plutonium-238 Dioxide in Rats." Radiat. Res. 71:528-546.

Sanders, C L., and K. McDonald. 1986. "Low-Level 239PUO 2 Lifespan Studies." Pacific Northwest Laboratory Annual Report for 1985 to the Department of Energy Office of Energy Research, Part 1. Biomedical Sciences, pp. 31-35, U.S. Department of Energy, Washington, D.C., PNL-5750, Pacific Northwest Laboratory, Richland, Washington.

Sanders, C. L., K. McDonald, B. Killand, J. A. Mahaffey, and W. C. Cannon. 1986. "Low-Level Inhaled-239 $\mathrm{PuO}_{2}$ Lifespan Studies in Rats." In Life-Span Radiation Effects Studies in Animals: What Can They Tell Us? eds. R. Thompson and J. Mahaffey. Proceedings from the 22nd Hanford Life Sciences Symposium, Richland, Washington, pp. 429-449. DE87000490, National Technical Information Service, Springfield, Virginia.

Sauter, S., K. S. Buxton, K. J. Macek, and R. Petrocelli. 1976. Effects of Exposure to Heavy Metals on Selected Fresh Water Fish. Toxicity of Copper, Cadmium, Chromium and Lead to Eggs and Fry of Seven Fish Species. Environmental Protection Agency, Ecological Research Series, EPA Report 600/3-76-105.

Sax, N. I. 1984. Dangerous Properties of Industrial Materials. Van Nostrand Reinhold Co., New York, 6th Edition.

Schell, W. R., and R. L. Watters. 1975. "Plutonium in Aqueous Systems." Health Phys. 29:589-597.

Schieferdecker, H., H. Dilger, and H. Doerfel. 1985. "Inhalation of Uranium Aerosols from Uranium Dioxide Fuel Element Fabrication." Health Phys. 48:29-48.

Schnell, J. H. 1964. "Some Effects of Neutron-Gramma Radiation on Late Summer Bird Populations." Auk 81(4):528-533.

Schroeder, H. A. 1973. "Recondite Toxicity of Trace Elements." Essays Toxicol. 4:107-199.

Schroeder, H. A., J. J. Balassa, and W. H. Vinton, Jr. 1964. "Chromium, Lead, Cadmium, Nickel, and Titanium in Mice: Effect on Mortality, Tumors, and Tissue Levels." J. Nutr. 83:239-250.

Schroeder, H. A., J. J. Balassa, and W. H. Vinton, Jr. 1965. "Chromium, Cadmium, and Lead in Rats. Effects of Life Span, Tumors, and Tissue Levels." J. Nutr. 86:51-65.

Schuller, P. C. Lovengreen, and H. Handl. 1993. "137Cs Concentration in Soil, Prairie Plants, and Milk from Sites in Southern Chile." Health Phys. 64:157-161. 
-Schwartz, L., L. Tulipan, and S. Peck. 1947. A Textbook of Occupational Diseases of the Skin. Lea and Febiger, Philadelphia, Pennsylvania.

Shacklette, H. T., J. A. Erdman, T. F. Harms, and C. S. E. Papp. 1978. "Trace Elements in Plant Foodstuffs in Hazardous and Toxic Substances." Vol. 2. Toxicity of Heavy Metals in the Environment, ed. F. W. Oehme, pp. 25-68. Marcel Dekker, Inc., New York.

Sheppard, M. I. 1985. "The Plant Concentration Ratio Concept as Applied to Natural U." Health Phys. 48:494-500.

Sheppard, M. I., T. T. Vandergraaf, D. H. Thibault, and J. A. Kieth. 1983. "Technetium and Uranium: Sorption by and Plant Uptake from Peat and Sand." Health Phys. 44:635-643.

Sheppard, S. C., and W. G. Evenden. 1985. "Mobility and Uptake by Plants of Elements Placed Near a Shallow Water Table Interface." J. Environ. Qual. 14:544-560.

Sheppard, S. C., and W. G. Evenden. 1992. "Bioavailability Indices for Uranium: Effect of Concentration in Eleven Soils." Arch. Environ. Contam. Toxicol. 23:117-124.

Sheppard, S. C., M. I. Sheppard, and W. G. Evenden. 1990. "A Novel Method Used to Examine Variation in Tc Sorption Amoung 34 Soils, Aerated and Anoxic." J. Environ. Radioact. 11:215-233.

Sheppard, S. C., and W. G. Evenden. 1991. "Can Aquatic Macrophytes Mobilize Technetium by Oxidizing Their Rhizosphere?" J. Environ. Qual. 20:738-744.

Sheppard, S. C., W. G. Evenden, and A. J. Anderson. 1992. "Multiple Assays of Uranium Toxicity in Soil." Environ. Toxicol. Water Qual. 7:275-294.

Shibuya, M. and T. Nakai. 1963. "Study of the Neutron Activation Analysis of Inorganic Minor Elements in Plants and Soils. I. The Determination of Individual Rate Earth Elements in Rice Plants and Soils by Activation Analysis and Focusing Chromatography." Proc. Japan Conf. Radioisotopes 5(4):228-230.

Silker, W. B. 1958. Strontium-90 Concentrations in the Hanford Environs. HW-55117, Hanford Atomic Products Operation, General Electric Co., Richland, Washington.

Sissoeff, I., J. Grisvard, and E. Guille. 1976. "Effects of Metal Ions on Physicochemical Properties of DNA." Prog. Biophys. Mol. Biol. 31:165-199.

Skidmore, J. F., and I. C. Firth. 1983. Acute Sensitivity of Selected Freshwater Animals to Copper and Zinc. Technical Paper No. 81. Australian Water Resources Council, Australian Govemment Publishing Service, Canberra, Australian Capital Territory, Australia.

Sluis-Cremer, G. K., R. S. J. Dutoit. 1968. "Pneumoconiosis in Chromic Miners in South Africa." Brit. J. Ind. Med. 25:63-67.

Snyder, A. D., D. G. DeAngelis, E. C. Eimutus, D. M. Haile, J. C. Ochsner, R. B. Reznik, and H. D. Troy. 1977. Environmental Monitoring Near Industrial Sites: Chromium. 560/6-77-016, U.S. Environmental Protection Agency, Washington, D.C.

Snyder, F., E. A. Cress, and G. C. Kyker. 1959. "Lipid Responses to Intravenous Rare Earths in Rats." J. Lipid Res. 1:125-131. 
Snyder, W. S., M. J. Cook, E. S. Nasset, L. R. Karhausen, G. P. Howells, I. H. Tipton. 1975. Report of the Task Group on Reference Man. Publication 23, International Commission of Radiological Protection, New York.

Soni, R., and S. A. Abbasi. 1981. "Mortality and Reproduction in Earthworms Pheritima posthuma Exposed to Chromium (VI)." Int. J. Environ. Stud. 17:147-149.

Spigarelli, S. A., and J. Edwards. 1975. "Effect of Plume Residence on the Accumulation of ${ }^{137} \mathrm{Cs}$ by Lake Michigan Salmonids." Radiol. Environ. Res. Div. Annu. Rep. ANL-75-3, pp. 180-185, Argonne National Laboratory, Argonne, Illinois.

Srivastava, A., H. O. Denschlag, O. Kelber, and K. Urich. 1990. "Accumulation and Discharge Behavior of Cs-137 by Zebra Fish (Brachydanio rerio) in Different Aquatic Environments." J. Radioanal. Nucl. Chem. 138(1):165-170.

Stadler, J., and J. W. Gowen. 1964. Effects of lonizing Radiation on the Reproductive System, eds. W. D. Carlson, and F. X. Gassner, p. 111. Pergamon Press, Inc., New York.

Stannard, J. N. 1973. "Toxicology of Radionuclides." Annu. Rev. Pharmacol. 13:325-57.

Stara, J. F., N. S. Nelson, H. L. Kreiger, and B. Kahn. 1971. "Gastrointestinal Absorption and Tissue Retention of Radioruthenium." In Intestinal Absorption of Metal lons, Trace Elements and Radionuclides, eds. S. C. Skoryna and D. Walsron-Edward, p. 307. Pergamon Press, Inc., Oxford, England.

Stather, J. D., J. W. Harrison, H. Smith, P. Rodwell, and A. J. David. 1980. "The Influence of Fasting and Valence on the Gastrointestinal Absorption of Plutonium in Hamsters and Rabbits." Health Phys. 39:334-338.

Stegnar, P., and I. Kobal. 1982. "Uptake and Distribution of Radium and Uranium in the Aquatic Food Chain." In Abstracts and Program for the Proc. of the International Conference on Heavy Metals in the Environment, pp. C-69, Toronto, Canada.

Stevens, J. D., L. J. Davies, E. K. Stanley, R. A. Abbott, M. Ihnat, L. Bidstrup, and J. P. Jaworski. 1976. Effects of Chromium in the Canadian Environment. NRCC 15017, Natural Resource Council of Canada, Ottawa, Canada.

Stewart, A. J., G. J. Haynes, and M. I. Martinez. 1992. "Fate and Biological Effects of Contaminated Vegetation in a Tennessee Stream." Environ. Toxicol. Chem. 11:653-664.

Stokinger, H. E. 1981. "The Metals." In Industrial Hygiene and Toxicology, ed. F. A. Patty, 3rd Edition. Interscience Publishers, New York.

Stokinger, H. E, R. C. Baxter, H. P. Dygent, C. W. LaBelle, S. Laskin, U. C. Pozzani, E. Roberts, J. J. Rothermel, A. Rothestein, and C. S. Spiegel, G. F. Sprague III, H. B. Wildon, and R. G. Yaeger. 1953. "Toxicology Following Inhalation for 1 and 2 Years." In Pharmacology and Toxicology of Uranium Compounds, eds. I. C. Voegtlin and H. C. Hodge. McGraw-Hill Book Company, New York.

Strandberg, G. W., S. E. Schumate , and J. R. Parrot., Jr. 1981. "Microbial Cells as Biosorbent for Heavy Metals: Accumulation of Uranium by Saccharomyces cervisiae and Psudomonas aeruginosa." Appl. Envrion. Micobiol. 41(1):237-245.

Sugatt, R. H. 1980. "Effects of Sublethal Sodium Dichromate Exposure in Freshwater on the Salinity Tolerance and Serum Osmolality of Juvenile Coho Slamon, Oncrhynchus kisutch, in Scawater." Arch. Environ. Contam. Toxicol. 2(1):41-52. 
Sullivan, M. F. 1980. "Absorption of Actinide Elements from the Gastrointestinal Tract of Rats, Guinea Pigs and Dogs." Health Phys. 38:159-171.

Sullivan, M. F., P. L. Hackett, L. A. George, and R. C. Thompson. 1960. "Irradiation of the Intestine by Radioisotopes." Radiat. Res. 13:343-355.

Sullivan, M. F., T. R. Garland, D. A. Cataldo, and R. G. Schreckhise. 1979. "Absorption of PlantIncorporated Nuclear Fuel Cycle Elements from the Gastrointestinal Tract." In Biological Implications of Radionuclides Released from Nuclear Industries, Vol. II., pp. 447-457. IAEA-SM-237/58, International Atomic Energy Agency, Vienna., Austria.

Sullivan, M., B. Miller, and J. Goebel. 1984. "Gastrointestinal Absorption of Metals (Chromium-51, Zinc-65, Technetium-99, Cadmium-109, Tin-113, Promethium-147, and Plutonium-238) by Rats and Swine." Environ. Res. 35:439-453.

Surber, E. W. 1965. "Water Quality Criteria for Freshwater Fishes." Proc. 16th Ann. Conf. Southeastern Assoc. Game Fish Commr., pp. 435-436.

Swanson, S. M. 1983. "Levels of ${ }^{226} \mathrm{Ra},{ }^{210} \mathrm{~PB}$, and TOTAL U in Fish Near a Saskatchewan Uranium Mine and Mill." Health Phys. 45:67-80.

Swanson, S. M. 1985. "Food Chain Transfer of U-Series Radionuclides in Northern Saskatchewan Aquatic System." Health Phys. 49:747-770.

Takeda, H., and T. Iwakura 1992. "Incorporation and Distribution of Tritium in Rats Exposed to Tritiated Rice or Tritiated Soybean." J. of Rad. Res. 33(4):309-318.

Talbot, R. J., D. Newton, and A. J. Warner. 1992. "Metabolism of Injected Plutonium in Two Healthy Men." Health Phys. 65:41-46.

Tamino, G., L. Peretta, and A. G. Levis. 1981. "Effects of Trivalent and Hexavalent Chromium Physicochemical Properties of Mammalian Cell Nucleic Acids and Synthetic Polynucleotides." Chem. Biol. Interact. 37:309-319.

Tandon, S. K., D. K. Saxena, J. S. Gaur, and S. V. Chandra. 1979. "Comparative Toxicity of Trivalent and Hexavalent Chromium." Arch. Environ. Contam. Toxicol. 9:207-216.

Tannenbaum, A., and H. Silverstone. 1951. "Some Aspects of the Toxicology of Uranium Compounds." In Toxicology of Uranium Compounds, ed. A. Tannenbaum, pp. 59-96. McGraw-Hill Book Company, New York.

Taylor, F. G., Jr., and P. D. Parr. 1978. "Distribution of Chromium in Vegetation and Small Mammals Adjacent to Cooling Towers." J. Tenn. Acad. Sci. 53:87-91.

Taylor, G. N., C. W. Jones, P. A. Gardner, R. D. Lloyd, C. W. Mays, and K. E. Charrier. 1981. "Two

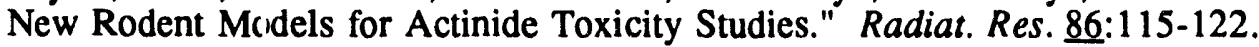

Taylor, G. N., C. W. Mays, R. D. Lloyd, P. A. Gardner, L. R. Talbot, D. VanMoorhem, D. Brammer, T. W. Brammer, G. Ayoroa, and D. Taysum. 1983. "Comparative Toxicity of $\mathrm{Ra}^{226}, \mathrm{Pu}^{239}, \mathrm{Am}^{241}$, $\mathrm{Cf}^{249}$, and Cf 252 in C57BL/Do Black and Albino Mice." Radiat. Res. 95:584-601.

Taylor, G. N., Lloyd, R. D., and Mays C. W. 1993. "Liver Cancer Induction by $\mathrm{Pu}^{239}, \mathrm{Am}^{241}$, and Thorotrast in the Grasshopper Mouse, Onychomys leucogaster." Health Phys. 64:141-146.

Tazwell, C. M. and C. Henderson. 1960. "Toxicity of Less Common Metals to Fish." Ind. Wastes 5:52-67. 
Templeton, W. L., and V. M. Brown. 1963. "Accumulation of Calcium and Strontium by Brown Trout from the Waters in the United Kingdom." Nature 198:198-200.

Templeton, W. L., and V. M. Brown. 1964. "The Relationship Between the Concentrations of Calcium, Strontium and Strontium-90 in Wild Brown Trout, Salmo trutta L. and the Concentrations of the Stable Elements in Some Waters of the United Kingdom, and the Implications in Radiological Health Studies." Intern. J. Air Water Pollut. 8:49-75.

Tester, J. R. 1968. "Effects of Ionizing Radiation on Pair-Formation in the Green-Winged Teal, Anas crecca carolinensis," p. 6; "Effect of Ionizing Radiation on Territorial Behavior in the Shoveler, Anas clypeata," p. 8; "Effects of Ionizing Radiation in the Blue-Winged Teal, Anas discors," p. 11." In Effects of Ionizing Radiation and Other Environmental Factors on Breeding Behavior, Activity Patterns and Movement of Selected Vertebrates, July, 1966 through June, 1967, Progress Report USAEC. University of Minnesota Contract AT(11-1)-1332.

Thomas, J. M., L. L. Cadwell, D. A. Cataldo, T. R. Garland, and R. E. Wildung. 1984. "Concentration of Orally A dministered and Chronically Fed ${ }^{95 \mathrm{~m}}$ Tc in Japanese Quail Eggs." Health Phys. 46(3):657-663.

Thompson, R. C., and J. E. Ballou. 1956. "Studies of Metabolic Tumover with Tritium as a Tracer. V. The Predominantly Non-Dynamic State of Body Constituents in the Rat." J. Biol. Chem. 223:795-809.

Thompson, S. E., C. A. Burton, D. J. Quin. 1972. Concentration Factors of Chemical Elements in Edible Aquatic Organisms. Lawrence Livermore National Laboratory, University of California, Livermore, California.

Thompson, S. E., C. E. Burton, D. J. Quin, and Y. C. Ng. 1972. Concentration Factors of Chemical Elements in Edible Aquatic Organisms. UCRL-50564, Rev. 1, Lawrence Radiation Laboratory, University of Califomia, Livermore, California.

Till, J. E. 1978. "The Effect of Chronic Exposure to 238Pu(IV) Citrate on the Embryonic Development of Carp and Fathead Minnow Eggs." Health Phys. 34:333-343.

Till, J. E., and B. G. Blaylock 1976. "The Chemical and Radiological Toxicity of Plutonium to Developing Embryos of Fish." Radiation Res. 67:5526-527.

Till, J. E., S. V. Kayue, and J. R. Trablaka. 1976. Toxicity of Uranium and Plutonium to the Developing Embryos of Fish. NTIS (ORNL-5160), Springfield, Virginia.

Toohey, R., M. Bhattacharyya, R. Oldham, R. P. Larsen and E. S. Moretti. 1984. "Retention of Plutonium in the Beagle After Gastrointestinal Absorption." Radiat. Res. 27:373-379.

Touchberry, R. W., and F. A. Verley. 1964. "Some Effects of X-Irradiation in Successive Generations on an Inbred and a Hybrid Population of Mice." Genetics 50:1187-1209.

Towill, L. E., C. R. Shriner, J. S. Drury, A. S. Hammons, and J. W. Holleman. 1978. Reviews of the Environmental Effects of Pollutants: III Chromium. 600/1-78-023, U.S. Environmental Protection Agency, Washington, D.C.

Trabalka, J. R., and L. D. Eyman. 1976. "Distribution of Plutonium-237 in a Littoral Freshwater Microcosm." Health Phys. 31:390-393.

Trabalka, J. R., and M. L. Frank. 1978. "Trophic Transfer by Chironomids and Distribution of Plutonium-239 in Simple Aquatic Microcosms." Health Phys. 35:492-494. 
Trama, F. B. 1954. "The Acute Toxicity of Some Common Salts of Sodium, Potassium, and Calcium to the Common Bluegill (Lepomis macrochirus Rafinesque)." Proc. Acad. Nat. Sci. Philadelphia 106:185-205.

Trama, F. B., and R. J. Benoit. 1960. "Toxicity of Hexavalent Chromium to Bluegills." J. Water Pollut. Control Fed. 32(8):868-877.

Turner, C. A., and E. W. Kienholz. 1972. "Nitrate Toxicity." Feedstuffs. Nov. 27:28-30.

Tyler, S. A., S. P. Stearner, and H. D. Muller. 1967. "Radiation Effect of Growth on the Chicken X-Irradiated During Embryonic Development." Radiat. Biol. 5:83-144.

U.S. Department of Agriculture (USDA). 1981. The Health Effects of Nitrate, Nitrite, and N-Nitroso Compounds, Part 1 of 2-Part Study by the Committee in Nitrite and Altemative Curing Agents in Food. 53-3A94-0-18. National Academy of Science, Washington, D.C.

U.S. Department of Energy (U.S. DOE). 1974. Proceedings of the Workshop held November 1214, 1975, Workshop on Environmental Research for Transuranic Elements. Battelle Seattle Research Center, Seattle, Washington.

U.S. Department of Energy (U.S. DOE). 1991. RCRA Facility Investigation Report for Waste Area Grouping 6 at Oak Ridge National Laboratory, Oak Ridge, Tennessee. Vol. II, Section 2 - 9. ORNL/ER/Sub--87/99053/5/V2, Report to Department of Energy, Washington, D.C., by Bechtel National, Inc., Oak Ridge, Tennessee.

U.S. Department of Energy (U.S. DOE). 1992. Sampling and Analysis of 100 Area Springs. DOE/RL-92-12, U.S. Department of Energy, Richland, Washington.

U.S. Department of Energy (U.S. DOE). 1993. Columbia River Impact Evaluation Plan. DOE/RL-92-28. U.S. Department of Energy, Richland, Washington.

U.S. Environmental Protection Agency (U.S. EPA). 1980. Ambient Water Quality Criteria for Chromium.. NTIS Report No. EPA-440/5-80-035, U.S. Environmental Protection Agency, Criteria and Standards Division, Washington, D.C.

U.S. Nuclear Regulatory Commission (U.S. NRC). 1977. Calculation of Annual Doses to Man from Routine Releases of Reactor Effluents for the Purpose of Evaluating Compliance with 10 CFR Part 50, Appendix I, Regulatory Guide 1.109. U.S. NRC, Washington, D.C.

Underbrink, A. G., A. H. Sparrow, and V. Pond. 1968. "Chromosomes and Cellular Radiosensitivity. II. Use of Interrelationships Among Chromosome Volume, Nucleotide Content and Do of 120 Diverse Organisms in Predicting Radiosensitivity." Radiat. Botany 8:205-237.

Underbrink, A. G., and A. H. Sparrow. 1974. "The Influence of Experimental End-Points, Dose, Dose Rate, Neutron Energy, Nitrogen Ions, Hypoxia, Chromosome Volume and Ploidy on RBE in Tradescantia Stamen Hairs and Pollen." In Biological Effects of Neutron Irradiation, pp. 185-214. International Atomic Energy Agency, Vienna, Austria.

Underwood, E. J. 1977. Trace Elements in Human and Animal Nutrition, 4th ed. Academic Press, Inc., New York.

United Nations Scientific Committee on the Effects of Atomic Radiation (UNSCEAR). 1982.

lonizing Radiation: Sources and Biological Effects. United Nations, New York. 
United Nations Scientific Committee on the Effects of Atomic Radiation (UNSCEAR). 1986. Sources and Effects of lonizing Radiation. United Nations, New York.

United Nations Scientific Committee on the Effects of Atomic Radiation (UNSCEAR). 1988. Sources, Effects, and Risks of lonizing Radiation. United Nations, New York.

Uyeki, E. M., and A. Nishio. 1983. "Antiproliferative and Genotoxic Effects of Chromium on Cultured Mammalian Cells." J. Toxicol. Environ. Health 11:227-235.

Van Bruwaene, R., G. B. Gerber, R. Kirchmann, C. T. Garten, Jr., J. Vankerkom, S. Bonotto, T. Mathieu, and M. Cogneau. 1986. "Absorption and Retention in Sheep of Technetium Administered into the Rumen as Pertechnetate or Bound to Food." In Technetium in the Environment, eds. G. Desmet and C. Myttenaere. Elsevier Applied Science Publ., New York.

Van Den Hoek, J., and M. H. J. Ten Have. 1983. "The Metabolism of Tritium and Water in the Lactating Dairy Cow." Health Phys. 44:127-133.

Van der Borght, O. 1963. "Accumulation of Radium-226 by the Freshwater Gastropod Lymnaea stagnalis L. Nature 197:612-619.

Van der Putte, I., M. A. Brinkhorst, and J. H. Koeman. 1981. "Effect of pH on the Acute Toxicity of Hexavalent Chromium to Rainbow Trout (Salmo gairdneri)." Aquatic Toxicol. (Netherlands) $1(2): 129-142$.

Van Loon, L. R., G, M. Desmet., and A. Cremers. 1989. "The Uptake of TcO4. by Plants: A Mathematical Description." Health Phys. 57:309-314.

Van Netten, C., and D. R. Morley. 1983. "Uptake of Uranium Molybdenum Copper and Selenium by the Radish from Uranium Rich Soils." Arch Env. Health 38:172-175.

Vanderploeg, H. A., D. C. Parzyck, and W. H. Wilcox, J. R. Kercher, and S. V. Kaye. 1975. Bioaccumulation Factors for Radionuclides in Freshwater Biota, Oak Ridge National Laboratory Report ORNL-5002.

Vaughan, A. T. M., D. J. Gordon, D. R. Chettle, and S. Green. 1991. "Neutron and Cobalt-60 g Irradiation Produce Similar Changes in DNA Supercoiling." Radiat. Res. 127:19-23.

Venugopal, B., and T. D. Luckey. 1978. Metal Toxicity in Mammals. Chemical Toxicity of Metals and Metalloids, Vol. 2, pp. 21-24. Plenum Press, New York.

Visek, W. J. I. B. Whitney, U. S. G. Kuhn, III, and C. L. Comer. 1953. "Metabolism of Cr-51 by Animals as Influenced by Chemical State." Proc. Soc. Exp. Biol. Med. 84:610-615.

Voelz, G. L., A. P. Stevenson, and C. C. Stewart. 1989. "Does Plutonium Intake in Workers Affect Lymphocyte Function?" Rad. Prot. Dosimet. 26(1/4):223-226.

Voelz, G., L. Hempelmann, J. Lawrence, and W.O. Mass. 1979. "A 32-Year Medical Follow-Up of Manhattan Project Plutonium Workers." Health Phys. 37:445-485.

Voight, G., K. Henrichs, G. Prohl, and H. G. Paretzho. 1988. "Measurements of Transfer Coefficients for ${ }^{137} \mathrm{Cs},{ }^{60} \mathrm{Co},{ }^{54} \mathrm{Mn},{ }^{22} \mathrm{Na},{ }^{131} \mathrm{I}$ and ${ }^{95 \mathrm{~m}} \mathrm{Tc}$ from Feed into Milk and Beef." Radiat. Environ. Biophys. 27:143-152.

Voight, G., G. Prohl, and H. Mueller. 1991. "Experiments on the Seasonality of the Cesium Translocation in Cereals, Potatoes, and Vegetables." Radiat. Environ. Biophys. 30(4):295-304. 
Vokal, H., E. Hellsten, A. Hendriksson-Enflo, M. Sundbom. 1975. Chromium., p. 22. Report 7621, Institute of Physics, University of Stockholm, Sweden.

Voors, P. I., and A. W. Yan Weers. 1991. "Transfer of Chemobyl Radiopcaesium $\left({ }^{134} \mathrm{Cs}\right.$ and $\left.{ }^{137} \mathrm{Cs}\right)$ from Grass Silage to Milk in Dairy Cows." J. Environ. Radioactivity 13:125-140.

Voshell, Jr., J. R., Eldridge, J. S., T. W. Oakes. 1985. "Transfer of ${ }^{137} \mathrm{Cs}$ and ${ }^{60} \mathrm{Co}$ in a Waste Retention Pond with Emphasis on Aquatic Insects." Health Phys. 49:777-789.

Vosniakos, F., A. Kesidous, A. Kalfa, and A. Moumtzis. 1991. "Uptake of ${ }^{137}$ Cs in Cultured Fresh Water Fish (Cyprinus carpio): Physiological and Histological Effects." Toxicol. Environ. Chem. 31-32:353-356.

Wagner, R. H., and T. G. Marples. 1966. "The Breeding Success of Various Passerine Birds Under Chronic Gamma -Irradiation Stress." Auk 83(3):437.

Wahlberg, J. E. 1973. "Thresholds of Sensitivity in Metal Contact Allergy. I. Isolation and Simultaneous Allergy to Chromium, Cobalt, Mercury, and/or Nickel." Berufsdermatosen 21:22-33.

Waite, D. T., S. R. Joshi, and H. Sommerstad. 1988. "The Effect of Uranium Mine Tailings on Radionuclide Concentrations in Langley Bay, Saskatchewan, Canada." Arch. Envrion. Contam. Toxicol. 17:373-380.

Waite, D. T., S. R. Joshi, H. Sommerstad, G. Wobeser, and A. A. Gajadhar. 1990. "A Toxicological Examination of Whitefish (Coregonus Clupeaformis) and Northern Pike (Esox lucius) Exposed to Uranium Mine Tailings." Arch. Environ. Contam. Toxicol. 19:578-582.

Wald, P. H., and V. A. Mode. 1989. A Review of the Literature on the Toxicity of Rare-Earth Metals as it Pertains to the Engineering Demonstration System Surrogate Testing. UCID 21823 Rev. 1 Lawrence Livermore National Laboratory, University of California, Livermore, California.

Wald, P. H., V. A. Mode. 1990. A Review of the Literature on the Toxicity of Rare-Earth Metals as it Pertains to the Engineering Demonstration System Surrogate Testing. DE90-008049, UCid-21823-Rev-1, Lawrence Livermore National Laboratory, Livermore, California.

Waldbott, G. L. 1973. Health Effects of Environmental Pollutants. C. V. Mosby Co., St. Louis, Missouri.

Walker, J. R., and T. A. Brindley. 1963. "Effect of X-Ray Exposure on the European Corn Borer." J. Econ. Entomol. 56:522-525.

Wallen, I. E., W. C. Greer, and R. Lasater. 1957. "Toxicity to Gambucia affinis of Certain Pure Chemicals in Turbid Waters." Sewage Ind. Wastes 29 (6):695-711.

Warnick, S. L., and H. L. Bell. 1969. "The Acute Toxicity of Some Heavy Metals to Different Species of Aquatic Insects." J. Water Pollut. Control Fed. 41:280-284.

Wedeen, R. P., and L. Qian. 1991. "Chromium-Induced Kidney Disease." Environ. Health Perspect. 92:71-74.

Weeks, M., and W. Oakley. 1955. "Percutaneous Absorption of Plutonium Solutions in Rats." Biology Research Annual Report 1954 to U.S. Atomic Energy Commission, Washington, D.C. HW-3047, Hanford Atomic Products Operation, Richland, Washington.

Westin, D. T. 1974. "Nitrate and Nitrite Toxicity to Salmonid Fishes." Prog. Fish-Cult. 36:86. 
Whicker, F. W., and V. Schultz. 1982. Radioecology: Nuclear Energy and the Environment, Volumes 1 and 2. CRC Press, Inc., Boca Raton, Florida.

Whicker, F. W., C. A. Little, and T. F. Winsor. 1973. Symposium on Environmental Surveillance Around Nuclear Installations, 5-9 November 1973, Warsaw, Poland. International Atomic Energy Agency, Vienna, Austria.

Wildung, R. E., and T. R. Garland. 1974. "Influence of Soil Plutonium Concentration of Plutonium Uptake and Distribution in Shoots and Roots of Barley." J. Agric. Food Chem. 22:836-838.

Wildung, R. E., D. A. Cataldo, and T. R. Garland. 1985. "Volatilization of Iodine from Soils and Plants." In Speciation of Fission and Activation Products in the Environment, eds. R. A. Bulman and J. R. Cooper, pp. 243-249. Elsevier Applied Science Publ., London, England.

Wildung, R. E., F. M. Desmet, D. A. Cataldo, and S. G. Weiss (ed.) 1989. "The Behavior of Technetium in Terrestrial and Aquatic Environs: A Symposium." Health Phys. 57:235-351.

Wildung, R. E., T. R. Garland, and D. A. Cataldo. 1977. "Accumulation of Technetium by Plants." Health Phys. 32:314-317.

Wildung, R. E., T. R. Garland, and D. A. Cataldo. 1979. "Environmental Processes Leading to the Presence of Organically Bound Plutonium in Plant Tissues Consumed by Animals." In Biological Implications of Radionuclides Released from Nuclear Industries, Vol. II., pp. 319-334.

IAEA-SM-237/37, International Atomic Energy Agency, Vienna, Austria.

Wildung, R., and T. Garland. 1980. "The Relationship of Microbial Processes to the Fate and Behavior of Transuranic Elements in Soils, Plants, and Animals." In Transuranic Elements in the Environment, ed. W. Hanson. DOE/TIC-22800, National Technical Information Service, Springfield, Virginia.

Wilhm, J. L. 1970. "Transfer of Radioisotopes Between Detritius and Benthic Macroinvertebrates in Laboratory Microecosystems." Health Phys. 18:277-284.

Willard, W. A. 1963. "Relative Sensitivity of Nestlings of Wild Passerine Birds to Gamma Radiation." In Radioecology, eds. V. Shultz and A. W. Clement, pp. 345-349. Van Nostrand Reinhold, New York.

Willard, W. K. 1960. "Avian Uptake of Fission Products from an Area Contaminated by Low-Level Atomic Wastes." Science 132(3420):148-150.

Williams, R. M. 1980. "Uranium." In Canadian Mineral Yearbook 1978, pp. 477-489. Energy Mines and Resources, Ottawa, Canada.

Wilson, C. B., and T. H. Essig (eds.). 1970. Evaluation of Radiological Conditions in the Vicinity of Hanford for 1969. BNWL-1505, Battelle-Northwest, Richland, Washington.

Wilson, D. O., and J. F. Cline. 1966. "Removal of Pu-239, W-185 and Pb-210 from Soils." Nature 209:941-942.

Winsor, T. F., and T. P. O'Farrell. 1970. "The Retention of ${ }^{137}$ Cs by Great Basin Pocket Mice." In Pacific Northwest Laboratory Annual Report for 1969. USAEC Report BNWL-1306 (Pt. 2), pp. 2.17-2.18, Battelle, Pacific Northwest Laboratories, Richland, Washington.

Witmer, C. M., R. Harris, S. I. Shupack. 1991. "Oral Bioavailability of Chromium from a Specific Site." Environ. Health Perspect. 22:105-110. 
Wolff, I. A., and A. E. Wasserman. 1972. "Nitrates, Nitrites, and Nitrosamines." Science. 177:15-19.

Wolmarans, C. T., E. Yssel, and V. L. Hamilton-Attwell. 1988. "Toxic Effects of Chromium on Schistosoma haematobium miracidia." Bull. Environ. Contam. Toxicol. 41:928-935.

Woodwell, G. M. 1970. "Effects of Pollution of the Structure and Physiology of Ecosystems." Science 168(3930):429-433.

World Health Organization (WHO). 1978. WHO Task Group on Environmental Health Criteria 5: Nitrates, Nitrites, and N-Nitroso Compounds. RID:78-325225 World Health Organization, Lyons, France.

World Health Organization (WHO). 1983. Environmental Health Criteria 25: Selected Radionuclides, pp. 169-229. World Health Organization, Geneva, Switzerland.

World Health Organization (WHO). 1985. Guidelines on Organic Micropollutants. International Symposium on Organic Micropollutants in Drinking Water and Health. Amsterdam, The Netherlands, June 11-14, 1985. Sci. Total Environ. 47(0):83-92.

Wrenn, M. D. E., P. W. Durvin, B. Howard, J. Lipsztein, J. Rundo, E. T. Still, and D. L. Willis. 1985. "Metabolism of Ingested U and Ra." Health Phys. 48:601-633.

Yamaguchi, S., K. Sano, and N. Shimojo. 1983. "On the Biological Half-Time of Hexavalent Chromium in Rats." Indust. Health 21:25-34.

Yudina, R. V. 1970. "Data on the Biological Effect of Small Amounts of Natural Uranium in Water." Hyg. Sanit. (U.S.S.R.) p. 63-71.

Zach, R., and K. R. Mayoh. 1982. "Breeding Biology of Tree Swallows and House Wrens in a Gradient of Gamma-Radiation." Ecology 63:1721-1728.

Zach, R., and K. R. Mayoh. 1984. "Gamma-Radiation Effects on Nestling Tree Swallows." Ecology 65:1641-1647.

Zach, R., and K. R. Mayoh. 1986a. "Gamma-Irradiation of Tree Swallow Embryos and Subsequent Growth and Survival." Condor 88:1-10.

Zach, R., and K. R. Mayoh. 1986b. "Gamma-Radiation Effects on Nestling House Wrens: A Field Study." Radiat. Res. 105:49-57.

Zach, R., J. L. Hawkins, and S. C. Sheppard. 1993. "Effects of Ionizing Radiation on Breeding Swallows at Current Radiation Protection Standards." Environ. Tox. Chem. 12:779-786.

Zanni, A. C. 1965. "Contribution to the Pharmacology of Europium." Rev. Fac. Farm. Bioquim. (Univ. of Sao Paulo) 3:199-240.

Zeevaert, T., C. M. Vandercasteele, and R. Kirchmann. 1989. "Assessment of Dose to Man from Releases of ${ }^{99} \mathrm{Tc}$ in Fresh Water Systems." Health Phys. 57:337-343. 
Appendix A

Radiological Units

and

International Multiples and Submultiples 


\section{Appendix A}

\section{Radiological Units and International Multiples and Submultiples}

In 1985, a new system of units based on fundamental physical quantities replaced the less precisely defined radiation units found in the older literature. Described below are the new International System (SI) units and the radiation units commonly found in the older literature. The international multiples and submultiples used in the text of this report are also provided.

\begin{tabular}{|c|c|}
\hline Symbol & Unit \\
\hline $\mathrm{Ci}$ & Curie \\
\hline $\mathrm{Bq}$ & Becquerel \\
\hline $\mathbf{R}$ & Roentgen \\
\hline rad & $\operatorname{Rad}$ \\
\hline Gy & Gray \\
\hline $\mathrm{Q}$ (or QF) & Quality Factor \\
\hline rem & \\
\hline
\end{tabular}

\section{Description}

A unit of activity of a radionuclide. A curie is equal to $3.7 \times 1010$ disintegrations (i.e. nuclear transformations) per second.

SI unit of antivity of a radionuclide. One becquerel is equal to one disintegration (i.e. one nuclear transformation) per second.

A special unit of exposure for $x$ - or gamma radiation that describes the quantity of ionization that these radiations produce in the air. An exposure of one roentgen results in $2.58 \times 10^{-4}$ coulomb per kilogram of dry air.

A unit of absorbed dose for any ionizing radiation. $A$ rad is equal to 100 ergs absorbed per gram of any substance or 0.01 joule per kilogram. For water and soft tissues the absorbed dose per roentgen is between 0.93 and $0.98 \mathrm{rad}$. Therefore the roentgen and rad are nearly equivalent numerically.

SI unit of dose equal to 1 joule per kilogram. One gray $=100 \mathrm{rad}$.

A unit used for radiation protection purposes in conjunction with the absorbed dose that accounts for the varying effectiveness of different radiations in producing a given biological effects.

A unit of dose equivalent that is numerically equal to the dose in rads multiplied by the 


\begin{tabular}{lll} 
Sumbol Unit & \multicolumn{1}{c}{ Description } \\
Sv & Seivert & $\begin{array}{l}\text { quality factor and any other modifying } \\
\text { factors. (Under most conditions one rem is } \\
\text { about equal to on rad.) }\end{array}$ \\
K & kilo & $\begin{array}{l}\text { SI a unit of dose equivalent that is } \\
\text { numerically equal to the dose in grays } \\
\text { multiplied by the quality factor and any } \\
\text { other modifying factors. }\end{array}$ \\
$\mathrm{m}$ & milli & $10^{3}$ \\
$\mu$ & micro & $10-3$ \\
$\mathrm{n}$ & nano & $10-6$ \\
$\mathrm{p}$ & pico & $10-9$
\end{tabular}




\section{Distribution}

No. of

Copies

\section{OFFSITE}

12 DOE Office of Scientific and Technical Information

2 Washington State Department of Ecology

PV-11

Olympia, WA $98504-8711$

Attn: S. Cross

L. Goldstein

2 Washington State Department of Ecology

$7601 \mathrm{~W}$. Clearwater

Suite 102

Kennewick, WA 99336

Attn: D. Teel J. Phillips

Washington State Department of Wildlife

Lower River Road

Benton City, WA 99320

Attn: L. Fitzner

U.S. Army Corps of Engineers

Walla Walla, WA 99362

Attn: A. Foote

3 Golder Associates, Inc.

4104 148th Ave. NE

Redmond, WA 98052

Attn: L. Swenson

W. Wright

Library
No. of

Copies

2 IT Corp

1045 Jadwin Ave.

Suite C

Richland, WA 99352

Attn: J. Chiramonte

D. A. Myers

IT Corp

5301 Central Avenue NE

Albuquerque, NM 87108-1513

Attn: Linda Meyers-Schone

\section{ONSITE}

7 DOE Richland Operations Office

R. F. Brich A5-55

B. L. Foley A5-19

E. D. Goller A5-19

R. D. Hildebrand A5-55

R. G. McLeod A5-19

R. K. Stewart A5-19

K. M. Thompson A5-15

6 U.S. Environmental Protection Agency

P. R. Beaver B5-01

D. R. Einan B5-01

D. A. Faulk B5-01

L. E. Gadbois B5-01

P. S. Innis B5-01

D. R. Sherwood B5-01

Distr.1 
No. of

Copies

40 Westinghouse Hanford Company

M. A. Adams H6-01

R. A. Carlson H6-03

S. W. Clark H6-01

T. W. Ferns H6-26

M. J. Galbraith H6-02

K. A. Gano XO-21

R. F. Giddings N3-06

R. P. Henckel H6-02

J. E. Hulla H6-63

L. C. Hulstrom H6-03

A. R. Johnson H6-30

W. L. Johnson H6-04

C. J. Kemp H4-14

C. D. Kramer H6-04

D. S. Landeen H4-14

N. K. Lane H6-01 (5)

K. M. Leonard H6-22

J. G. Lucas H6-04

R. M. Mitchell H6-04

K. L. Peterson H4-14

C. J. Perikings XO-21

R. C. Roos H6-04

M. R. Sackschewsky H4-14

J. W. Schmidt H6-30

J. A. Stegen H6-02

R. S. Weeks H6-26

S. G. Weiss H6-02 (10)
No. of

Copies

21 Pacific Northwest Laboratory

C. J. Brandt K6-06

G. R. Bilyard K8-03

L. L. Cadwell P7-54

D. D. Dauble K6-54

C. J. Driver K4-12 (5)

S. L. Friant K6-13

R. Mazaika K6-60

K. M. Probasco K6-13

L. E. Rogers P7-54

M. E. Thiede K6-52

R. K. Woodruff K6-13

Publication Coordination

Technical Report Files (5)

Washington State Department of Wildlife

J. Hall K6-63 

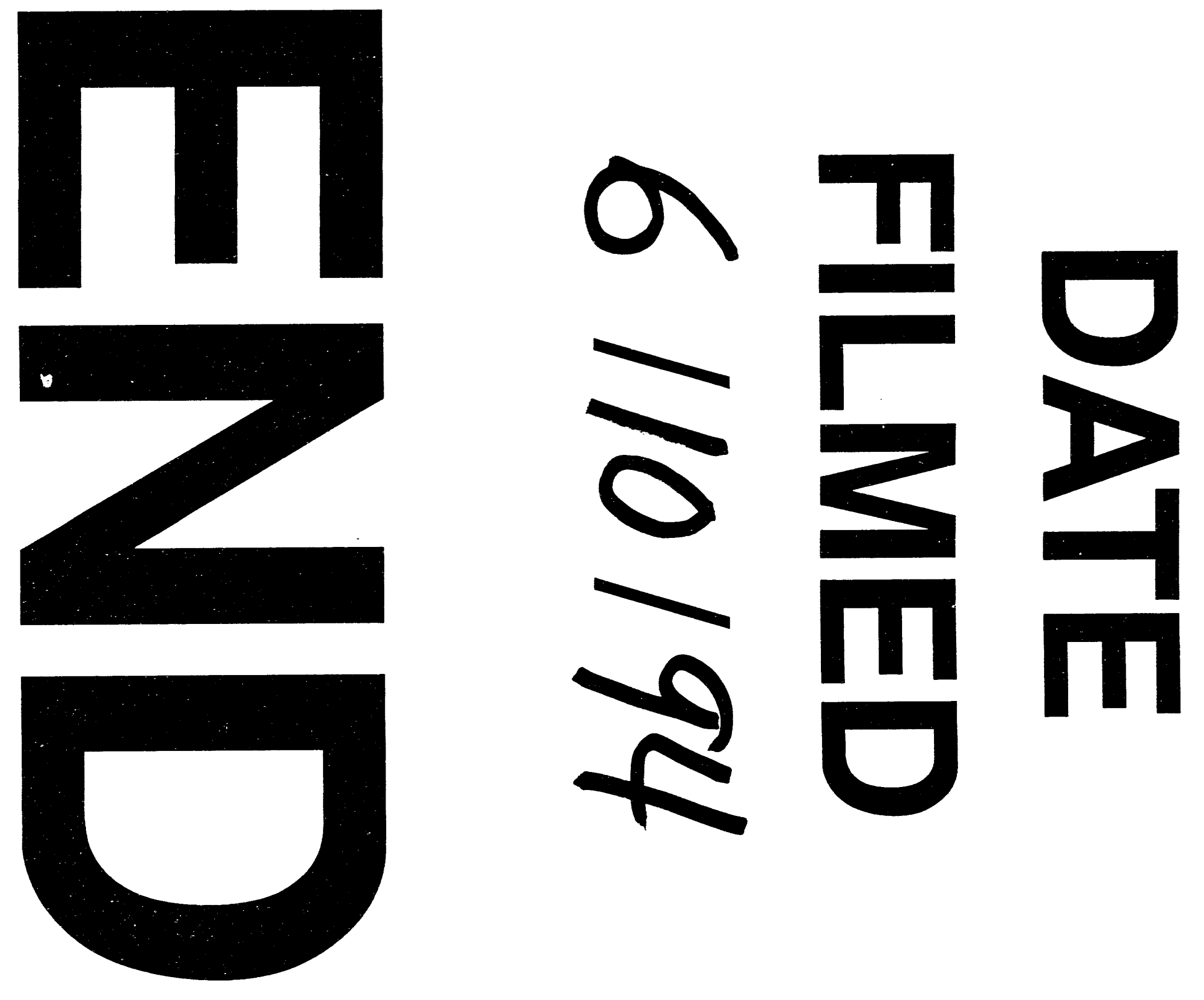
